\title{
SIMULAÇÕES COMPUTADORIZADAS DE FIXADORES INTERNOS DE COLUNA UTILIZANDO O MÉTODO DOS ELEMENTOS FINITOS
}

ANTONIO MARCOS DOS SANTOS

Dissertação apresentada ao Programa de Pós-Graduação Interunidades em Bioengenharia - Escola de Engenharia de São Carlos/Faculdade de Medicina de Ribeirão Pretol Instituto de Química de São Carlos da Universidade de São Paulo, para obtenção do título de Mestre em Bioengenharia.

Orientador: Prof. Dr. José Baptista Portugal Paulin

São Carlos 
A Deus o meu melhor amigo, minha mãe Geni minha primeira e grande professora 


\section{AGRADECIMENTOS}

- Ao Prof. Dr. José Baptista Portugal Paulin pela divisão de seu conhecimento, tempo e admirável atenção.

- Ao Prof. Dr. Antonio Carlos Shimano pela confiança, amizade, conselhos e ensinamentos prestados na realização deste trabalho.

- Venho especialmente agradecer ao Prof. Dr. Orivaldo Lopes da Silva e Prof. Dr. José Carlos Pereira pela presença em minha banca de qualificação.

- Aos funcionários do Laboratório da Bioengenharia pela amizade e atenção.

- Aos meus grandes amigos Eduardo, Élvio, Fernando, Henrique e Ricardo que foram como irmãos em minha estadia em São Carlos.

- Aos amigos da Bioengenharia: Adriana, Vera, Elaine, Irene, Marcos, Marcos Shimano, Nelson, Elizete, Angélica, Tatiana, Maira que estavam presentes na minha batalha demonstrando sempre sua amizade. 
- Ao meu grande amigo Wilson por estar presente nos momentos que mais precisei me dando força, conselhos, demonstrando toda sua amizade e mostrando-me o caminho da vitória.

- À secretária do Programa de Pós-Graduação em Bioengenharia, Janete dos Santos por ser mais que uma secretária e sim uma grande amiga mostrando-me toda sua riqueza espiritual. Obrigado!

- Ao Prof. Dr. Jonas de Carvalho (Engenharia Mecânica) pelo auxílio nas utilizações dos softwares de engenharia e por sua amizade.

- Aos meus amigos Gustavo, Murilo, Tatiane, Letícia, Adriana, Sérgia e Débora por ficarem felizes com as minhas vitórias e me aconselharem.

- À minha amiga Raquel o meu obrigado pela sua sabedoria do português na correção da minha dissertação. 


\section{SUMÁRIO}

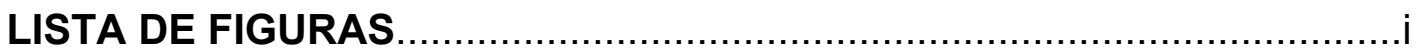

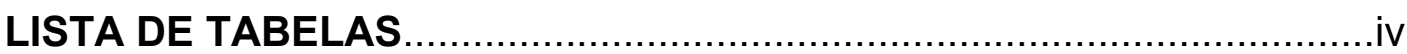

LISTA DE ABREVIATURAS E SIGLAS ...............................................

RESUMO

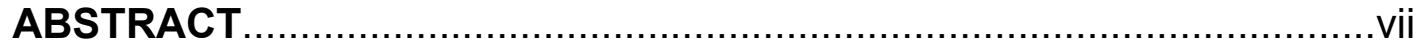

1 INTRODUÇÃO

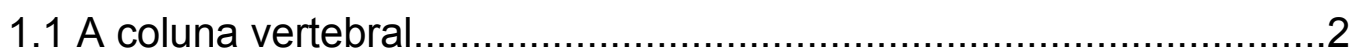

1.2 Principais fraturas da coluna vertebral...........................................

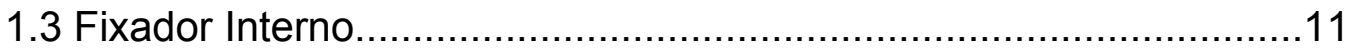

1.4 O Software SOLID EDGE................................................

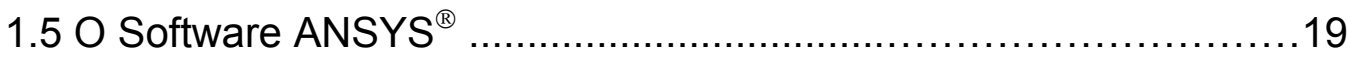

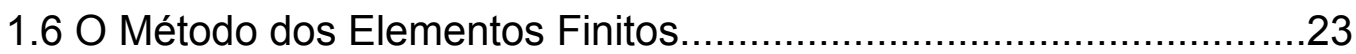

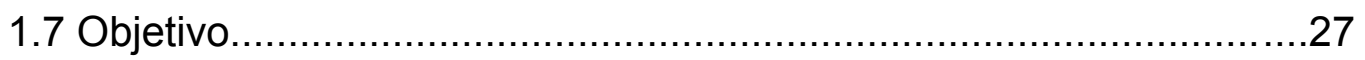

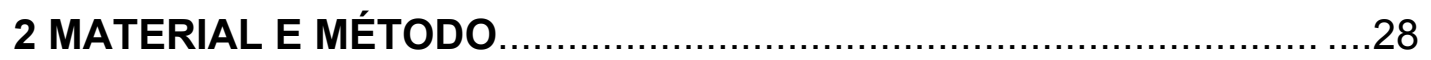

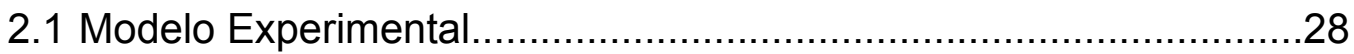

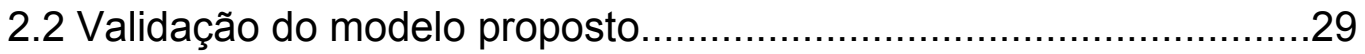

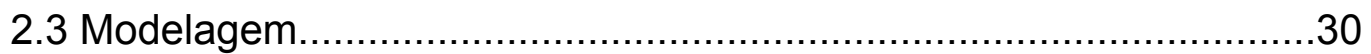

2.3.1 Procedimento da modelagem de uma das peças................31

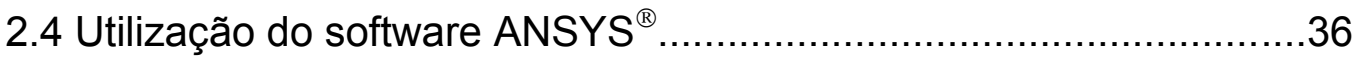

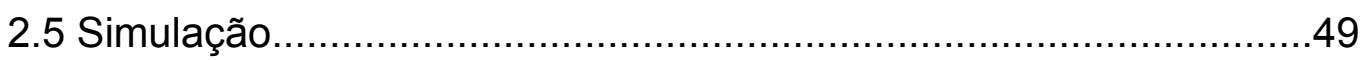

3 RESULTADOS

3.1 Ensaios realizados no fixador de titânio..........................................53

3.2 Ensaios realizados no fixador de alumínio......................................61

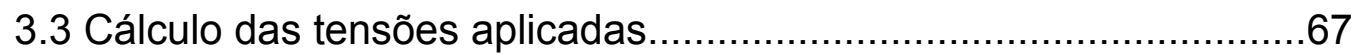

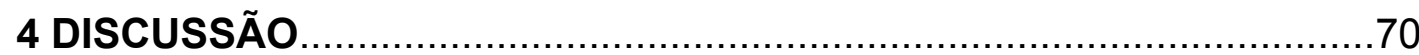

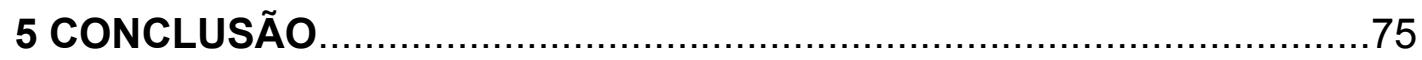

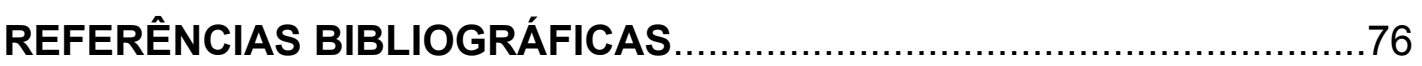




\section{LISTA DE FIGURAS}

FIGURA 01 - A coluna vertebral, SOBOTTA (1993)....................................

FIGURA 02 - Classificação das fraturas, APLEY (1998)..................................5

FIGURA 03 - (A), (B) Fixações de fraturas.................................................... 13

FIGURA 04 - Modelagem no Solid Edge - Solid Edge Copyright ${ }^{\odot}$ 1996-2001

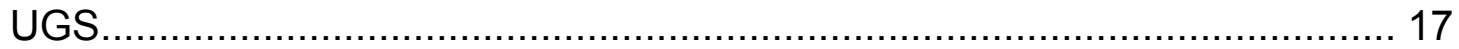

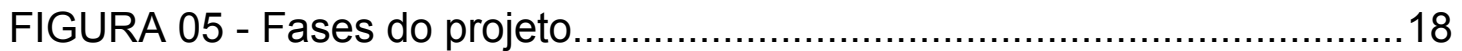

FIGURA 06 - Exemplo da utilização de Elementos Finitos..............................25

FIGURA 07 - Montagem dos componentes do Fixador.................................. 28

FIGURA 08 - Aplicação de uma carga de Flexo-compressão.......................... 29

FIGURA 09 - Aplicação de uma carga de Flexão lateral.................................. 30

FIGURA 10 - Interface gráfica do software Solid Edge.................................31

FIGURA 11 - (A), (B) Seleção do eixo de modelagem.................................. 32

FIGURA 12 - Escolha da ferramenta para Protusion.....................................32

FIGURA 13 - Diâmetro e Raio da Haste........................................................ 33

FIGURA 14 - Término do perfil da Haste...................................................... 33

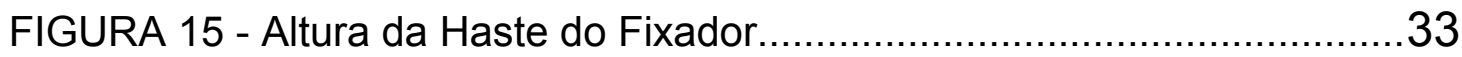

FIGURA 16 - Vista da peça em Wireframe Outline.........................................34

FIGURA 17 - Resultado da Haste no modo Shade........................................ 35

FIGURA 18 - Término da Haste do Fixador Interno de Coluna........................ 35

FIGURA 19 - Haste do Fixador salvo com a extensão IGES............................36

FIGURA 20 - Sólido Estrutural Tetraedro 923 D 10 Nós............................... 39

FIGURA 21 - Direções das tensões e Produções de tensões.......................... 40

FIGURA 22 - Elementos tetraedros do Fixador............................................ 41

FIGURA 23 - Importação do sólido no formato IGES ${ }^{\circledR}$.................................. 42

FIGURA 24 - Criação do volume da peça importada..................................... 43

FIGURA 25 - Utilização do comando de salvamento.....................................43 
FIGURA 26 - Determinação da preferência da disciplina. 44

FIGURA 27 - Adição do elemento tetraédrico. 45

FIGURA 28 - Definição das propriedades do material.................................... 46

FIGURA 29 - Tabela das propriedades do material. 46

FIGURA 30 - (A), Geração do tamanho do elemento. (B), Tabela de tamanho do elemento.

FIGURA 31 - Definição da malha tetraédrica................................................. 48

FIGURA 32 - Resultado final da geração das malhas.

FIGURA 33 - (A), Menu para aplicação de restrições. (B), Restrição da parte inferior do fixador.

FIGURA 34 - (A), Menu para aplicação das cargas. (B), Aplicação da carga na parte superior do Fixador 50

FIGURA 35 - Geração da solução. 52

FIGURA 36 - Aplicação de uma carga de 0,0365 KN em um ensaio de Flexocompressão 54

FIGURA 37 - (A), (B) Ponto de maior e menor tensão no Fixador durante o ensaio de Flexo-compressão. 56 FIGURA 38 - Deformação sofrida pelo Fixador de titânio no ensaio de Flexocompressão com carga de $0,0365 \mathrm{KN}$

FIGURA 39 - Aplicação de uma carga de 0,0365 KN em um ensaio de Flexão lateral

FIGURA 40 - (A), (B) Ponto de maior e menor tensão no Fixador durante o ensaio de Flexão lateral. 60 FIGURA 41 - Deformação sofrida pelo Fixador no ensaio de Flexão lateral com carga de $0,0365 \mathrm{KN}$. .59 FIGURA 42 - Aplicação de uma carga de 0,0365 KN em um ensaio de Flexocompressão no Fixador de alumínio 61 
FIGURA 43 - (A), (B) Ponto de maior tensão no Fixador durante o ensaio de Flexo-compressão. 63

FIGURA 44 - Deformação sofrida pelo Fixador de alumínio no ensaio de Flexo-compressão com carga de 0,0365 KN. 62

FIGURA 45 - Aplicação de uma carga 0,0365 KN em um ensaio de Flexão lateral no Fixador de alumínio.

FIGURA 46 - (A), (B) Ponto de maior e menor tensão no Fixador durante o ensaio de Flexão lateral. 66 FIGURA 47 - Deformação sofrida pelo Fixador de alumínio no ensaio de Flexão lateral com carga de 0,0365 KN. 65 FIGURA 48 - Gráfico das cargas aplicadas x tensões obtidas nos ensaios de Flexo-compressão do Fixador de titânio. 68 FIGURA 49 - Gráfico das cargas aplicadas x tensões obtidas nos ensaios de Flexo-compressão do Fixador de alumínio 68 FIGURA 50 - Gráfico das cargas aplicadas x tensões obtidas nos ensaios de Flexão lateral do Fixador de titânio 69 FIGURA 51 - Gráfico das cargas aplicadas x tensões obtidas nos ensaios de Flexão lateral do Fixador de alumínio 69 


\section{LISTA DE TABELAS}

TABELA 1 - Propriedades dos materiais................................................ 38

TABELA 2 - Valores para ensaios de carregamento................................ 53

TABELA 3 - Resultados gerais realizados nos ensaios de flexo compressão

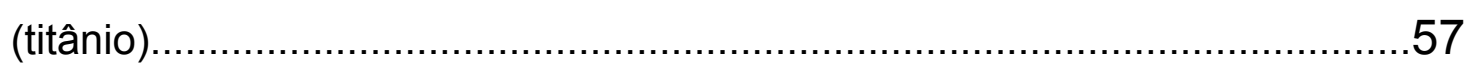

TABELA 4 - Resultados gerais realizados nos ensaios de flexão lateral

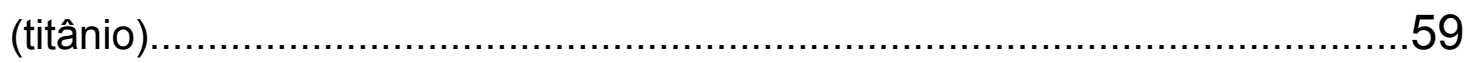

TABELA 5 - Resultados gerais realizados nos ensaios de flexo compressão

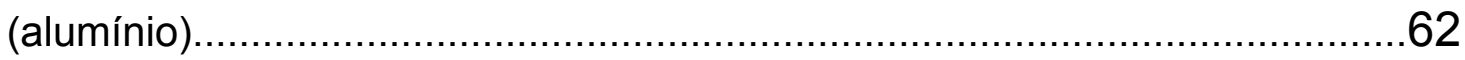

TABELA 6 - Resultados gerais realizados nos ensaios de flexão lateral

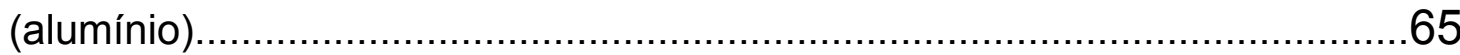




\section{LISTAS DE ABREVIATURAS E SIGLAS}

$\begin{array}{ll}\text { CAD } & \text { - Computer Aided Design } \\ \text { APDL } & \text { - ANSYS Parametric Desing Language } \\ \text { FEA } & \text { - Finite Element Analyse } \\ \text { MEF } & \text { - Método dos Elementos Finitos } \\ \text { NASA } & \text { - National Aeronautics and Space Administration } \\ \text { CAM } & - \text { Computer Aided Manufacturing } \\ \text { ANSYS } & - \text { ANSYS Inc. Corporate Information } \\ \text { IGES } & - \text { Initial Graphics Exchange Specification } \\ \text { MPa } & -10^{6} \text { Pascal. Pascal é a unidade de tensão no sistema } \\ & \text { internacional de unidade de medida e é igual a newton/metro } \\ & \text { quadrado }\end{array}$




\section{RESUMO}

Os problemas freqüentes de patologias ortopédicas e traumáticas da coluna vertebral envolvem a colocação de fixadores internos (parafusos longos, os quais são inseridos nos pedículos posteriores até os corpos vertebrais e conectados por fios nas hastes longitudinais podendo ser fixados em todas as posições pelas porcas). Estes fixadores foram simulados no computador através da construção de modelos geométricos dos mesmos, utilizando o software ANSYS ${ }^{\circledR} 5.5$, que consiste de várias ferramentas para análise do projeto baseado no método dos elementos finitos. Foi também utilizado um software para a modelagem das peças e do conjunto do fixador já existente chamado SOLID EDGE ${ }^{\circledR}$, e logo em seguida o mesmo foi transferido para o software ANSYS ${ }^{\circledR} 5.5$ e simulado. Esta comparação servirá como complemento para possíveis modificações das montagens, dimensões e aplicações, não necessitando de novos ensaios mecânicos na máquina universal de ensaios e sim realizando simulações computadorizadas.

Palavras-chaves: Elementos finitos, fixador interno, simulação. 


\section{ABSTRACT}

The frequent problems of orthopedic and traumatic pathologies of the spinal column that involves the placement of an internal fixator (long screws, which are inserted in the subsequent pedicle until the vertebral and connected by bodies for wires in the longitudinal stems could be fastened in all the positions by the screw). These fixators were simulate in the computer through the construction of geometric models of the same ones, using the software ANSYS ${ }^{\circledR} 5.5$, that consists of several tools for analysis of the project based on the method of the finite elements. It was also used a software for the modelling of the pieces and of the group of the fixador already called existent SOLID EDGE ${ }^{\circledR}$, and then the same was transferred te the software ANSYS5.5 and simulated. This comparison will serve a complement for possible modifications of the assemblies, dimensions and applications, not needing new mechanical test in the universal machine test but accomplishing computerized simulations.

Keywords: Finite elements, internal fixator, simulation. 


\section{INTRODUÇÃO}

Várias são as doenças que podem levar à instabilidade da coluna vertebral. Dentre as principais causas temos: os traumatismos, os tumores (primários e metastáticos) e as doenças degenerativas.

Ao longo dos anos, muitas técnicas e instrumentais cirúrgicos têm sido desenvolvidos com o objetivo de fixar a coluna vertebral.

A Biomecânica tem por sua vez importância fundamental no auxílio da fixação da coluna, onde realiza testes experimentais "In Vitro", tomando como relações fundamentais a padronização e os ensaios realizados.

Nos ensaios tecnológicos de matérias biológicos, quase sempre são feitos corpos de prova com dimensões padronizadas das partes que se deseja estudar ou determinar as propriedades mecânicas (SOUZA, 1977).

$\mathrm{Na}$ realização dos testes mecânicos, é fundamental à padronização de uma montagem que tem por objetivo avaliar a estabilidade através de propriedades mecânicas.

Estes testes são de grande importância, pois após uma cirurgia é conveniente que o sistema fixador interno $X$ estrutura óssea estejam sob um estado mecânico próximo ao osso inicial, promovendo uma maior durabilidade do fixador e reduzindo o número de cirurgias durante a vida do paciente. 


\subsection{A COLUNA VERTEBRAL}

A coluna vertebral contém vértebras ósseas alternadas com discos fibrocartilaginosos, conectados por ligamentos fortes e sustentadas por uma musculatura que se estende desde o crânio até à pelve, dando sustentação axial ao corpo.

Do ponto de vista macroscópico o sistema muscular proporciona movimento aos ossos que são elementos inertes e assim a coluna vertebral normal tem ampla movimentação.

O ser humano possui 33 vértebras sendo 7 cervicais, 12 torácicas, 5 lombares, 5 sacrais e 4 coccígeas (Fig. 1).

Cada vértebra tem duas partes distintas: uma anterior, formada pelo corpo vertebral e disco intervertebral, que é um suporte de sustentação e amortecedor de choque; e outra um segmento posterior que consiste em lâmina de arco vertebral, processo espinhoso e transverso e duas facetas articulares; este último segmento tem como função principal à orientação dos movimentos (MERCÚRIO, 1978).

A orientação da articulação dos processos é responsável pelo grau de flexão, extensão, ou rotação, assim os processos espinhosos e transversos servem como alavancas para os músculos unidos a estrutura. 
Por ocasião do nascimento, a coluna vertebral é dorsalmente convexa, formando o contorno sagital predominante; entretanto, quando
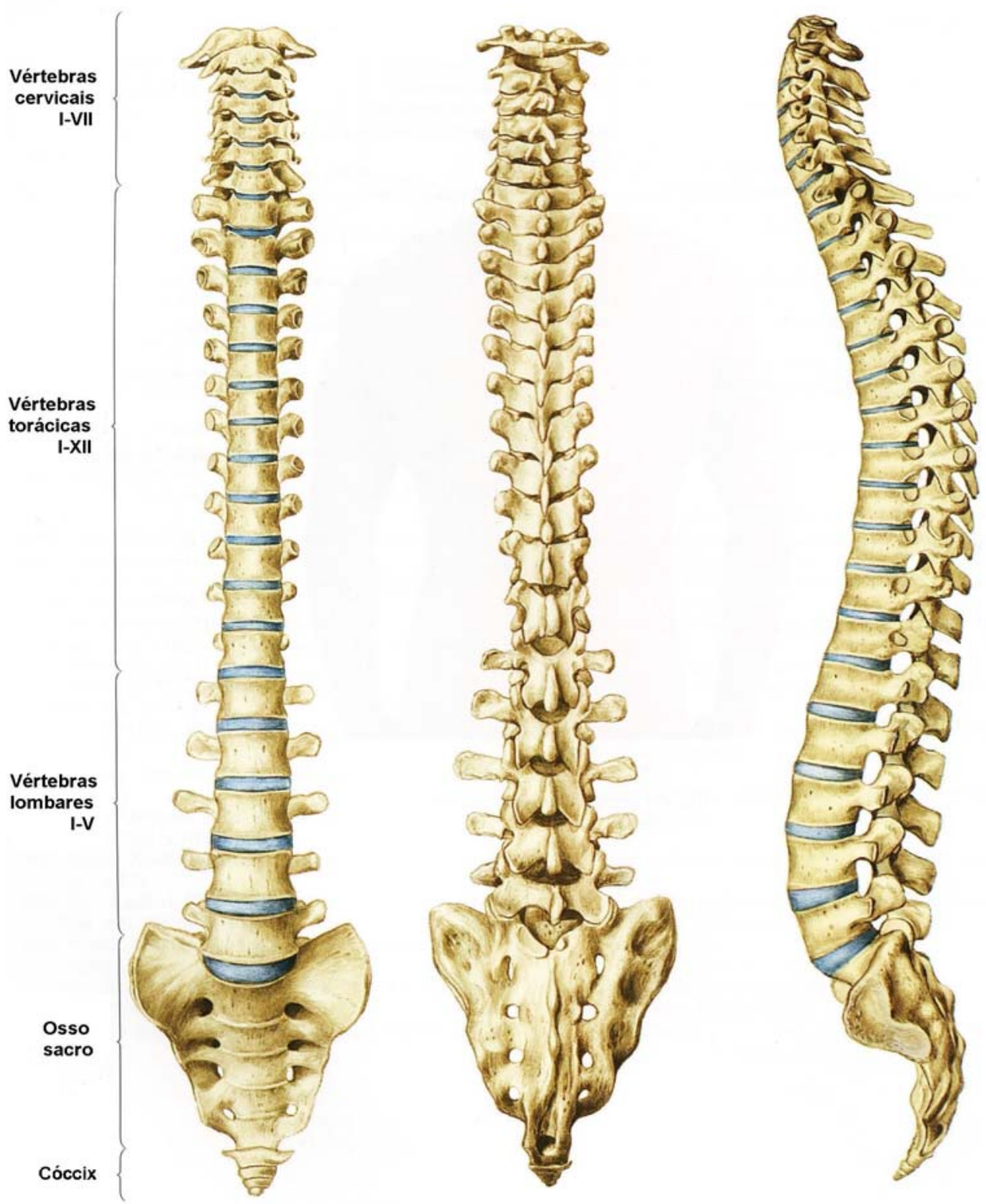

Fig. 1 - A coluna vertebral (PUTZ, R. \& PABST, R., 1993).

a posição ereta é adquirida, formam-se curvas lordóticas (cervical e lombar) compensatórias, opostas às curvas cifósicas primárias (torácica e sacral). O comprimento da coluna vertebral é, na média, de $72 \mathrm{~cm}$ em 
homens adultos de 7 a $10 \mathrm{~cm}$ menor em mulheres adultas. O canal vertebral estende-se ao longo de toda a extensão da coluna, proporcionando proteção para a medula espinhal, cone medular e cauda eqüina. Nervos e vasos passam através dos forames intervertebrais formados pelas bordas superiores inferiores dos pedículos de vértebras adjacentes (CRENSHAW, 1997).

\subsection{Principais Fraturas da Coluna Vertebral}

Nos últimos anos vem sendo notado um aumento no número de vítimas de lesões traumáticas da coluna vertebral, levando a um conseqüente aumento na população de pacientes tetraplégicos e paraplégicos por seqüela de traumatismo raquimedular (FILHO \& ROSSI 1992).

As causas mais freqüentes de trauma da coluna são os acidentes com veículos motorizados, quedas, acidentes de mergulho e ferimento por projéteis de arma de fogo.

Ao longo das últimas décadas, foram propostos diversos sistemas de classificação das lesões traumáticas da coluna vertebral, dentre os quais podemos citar os propostos por (HOLDSWORTH, 1963;1970; ROAF, 1960;1972; ALLEN, 1982; MAGERL, 1989; DENIS, 1990). Tais sistemas de classificação das lesões da coluna vertebral são geralmente baseados em aspectos radiológicos, atendo-se a parâmetros anatômicos e no mecanismo produtor da lesão para sua classificação. 
Em virtude da importância dos danos na medula, as fraturas da coluna são melhores classificadas como estáveis ou instáveis (Fig. 2). Nas fraturas estáveis, a medula raramente se encontra lesada, sendo a movimentação da coluna segura. Nas fraturas instáveis, a medula pode ter sofrido lesão, mas, caso não tenha, pode ainda ser danificada pelos movimentos subseqüentes (APLEY, 1998).

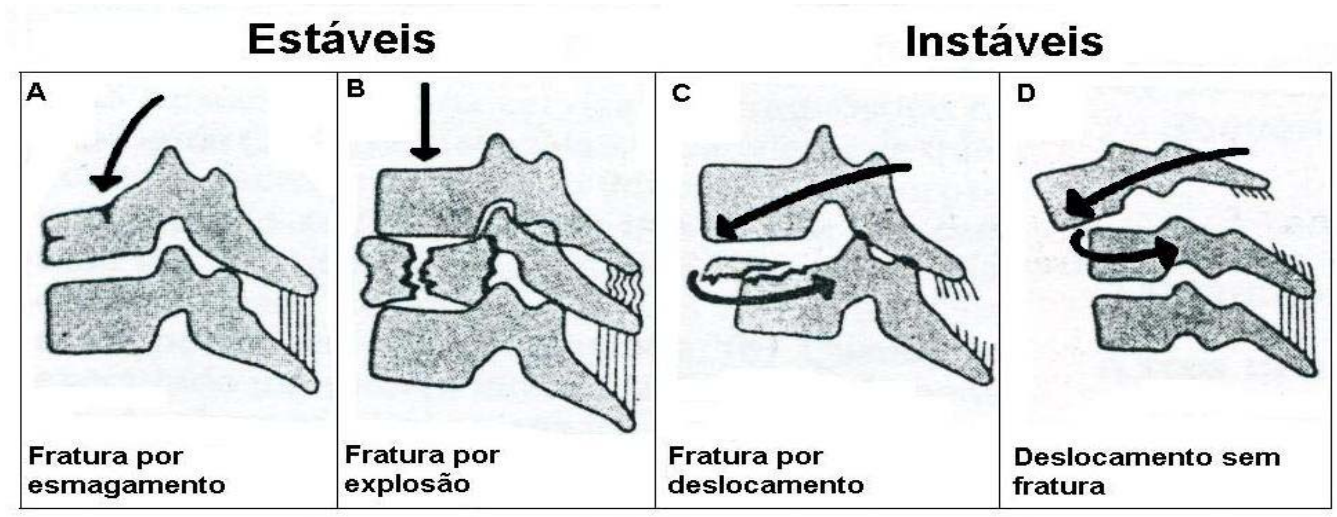

Fig. 2 - Classificação das fraturas (APLEY, 1998).

Fraturas de qualquer tipo na coluna podem envolver os corpos vertebrais ou os elementos posteriores - a apófise transversa e a apófise espinhosa. Lesões dos corpos vertebrais tendem a ocorrer decorrentes de compressão, flexão ou forças de torção; enquanto que os elementos posteriores são mais afetados por traumas diretos (ADAMS \& HAMBLEN, 1994).

Existem duas formas de classificação para as lesões da coluna cervical: a) anatomia patológica, e b) mecanismo que causa a lesão.

A primeira classificação está dividida em:

- Fraturas em cunha por compressão do corpo vertebral; 
- Fraturas por explosão do corpo vertebral;

- Subluxação por extensão;

- Subluxação por flexão;

- Deslocamento e Fratura-deslocamento;

- Fratura do Atlas;

- Fratura-deslocamento da articulação atlanto-axial;

- Deslocamento intra-espinhais das partes moles;

- Fratura dos processos espinhosos.

Os principais esforços que geralmente provocam as lesões da cervical são: flexão, flexão-rotação, extensão e compressão vertical.

$\mathrm{Na}$ coluna cervical as lesões maiores são geralmente causadas por traumas indiretos, tais como queda sobre a cabeça ou outro brusco movimento transmitidos pelo crânio.

- Fratura em cunha por compressão do corpo vertebral consiste em uma flexão intensa esmagando o osso esponjoso de uma ou mais vértebras. A compressão é mais intensa na parte anterior do corpo, que se torna encunhado, sendo que os ligamentos posteriores ficam intactos.

- Fratura por explosão de um corpo vertebral pode ser considerada uma variação da fratura em cunha por compressão, pois é causada pela força de compressão vertical passada diretamente ao longo da linha de corpos vertebrais, quando a coluna cervical está reta. Um dos espaços intervertebrais é rompido com a força transmitida e o disco é forçado para fora do corpo da vértebra tendo como efeito uma fratura 
cominuta por compressão, onde os fragmentos parecem ter sofrido uma explosão em todas as direções.

- Subluxação por extensão, o ligamento consiste no rompimento do longitudinal anterior por uma força intensa em extensão e os corpos se acham forçados anteriormente. A coluna se acha instável em extensão e estável quando o pescoço se acha na posição neutra ou em flexão, podendo a medula espinhal se manter ilesa ou não.

- Subluxação por flexão, ocorre quando há um deslocamento para frente de uma vértebra sobre a outra, mas este deslocamento não é suficiente para causar acavalgamento total dos processos articulares. No âmbito geral há um elemento rotacional no trauma causador do acavalgamento dos processos articulares, podendo ser parcial ou completo, em apenas um lado. A lesão geralmente ocorre na metade inferior da coluna cervical.

- Luxação e fratura-luxação são fraturas que ocorrem nos corpos vertebrais por compressão ou fratura do arco neural, onde as superfícies articulares perderam o contato e há acavalgamento dos processos articulares. É uma lesão instável e surpreendente, pois podem ocorrer deslocamentos graves sem lesão medular.

- Fratura do atlas ocorre por uma força vertical que atua sobre o crânio. O anel formado pelos arcos anteriores e posteriores do atlas são forçados e se abre pelo impacto dos côndilos occipitais. A medula freqüentemente não é atingida por lesões sérias e o deslocamento raramente é grande. 
- Fratura-luxação da articulação atlanto-axial é dependente do anel formado pelo arco anterior e o ligamento transverso do atlas sobre a apófise axial. Se o ligamento transverso sofrer uma lesão ou a apófise odontóide for fraturada, a estabilidade pode ser perdida. Quando o atlas é deslocado por trauma, quase sempre ocorre uma fratura na base da apófise odontóide, onde o fragmento se desloca junto com o atlas. Normalmente os deslocamentos são anteriores em lesões por flexão, e posteriores em lesão por extensão. Os deslocamentos anteriores são mais freqüentes, mas às vezes, há uma fratura da apófise odontóide sem deslocamento.

- Deslocamento intra-espinhais das partes moles é uma causa bem conhecida de compressão medular, onde o prolapso maciço do núcleo pulposo sofre uma lesão por uma força de compressão-flexão intensa.

- Fratura dos processos espinhosos é causada pela ação dos músculos em exercícios pesados e é denominada "fratura dos padejadores", pela incidência entre os padejadores. Afeta principalmente a sétima vértebra cervical ou a primeira torácica.

As lesões da coluna vertebral (torácica e lombar) podem ser classificadas como Fraturas grandes e deslocamentos das vértebras e Fraturas menos graves da coluna.

As Fraturas grandes e deslocamentos das vértebras são:

- Fraturas do corpo vertebral em cunha por compressão;

- Fratura do corpo vertebral por explosão; 
- Luxações fratura-luxação.

Dentre as Fraturas menos graves da coluna estão:

- Fraturas da apófise transversa;

- Fratura do sacro;

- Fratura do cóccix.

As fraturas toracolombares também são classificadas pelo mecanismo de lesão como: flexão, flexão e rotação, extensão, compressão vertebral e por cisalhamento.

- Fraturas em cunha por compressão do corpo vertebral provocam uma falha isoladamente na coluna anterior, resultado de um mecanismo de flexão. Uma fratura simples por compressão, geralmente é discreta e pode passar despercebido e raramente esta fratura está associada à deficiência neurológica, com exceção da ocorrência de vários níveis vertebrais adjacentes.

- Fraturas por explosão do corpo vertebral ocorrem quando as colunas anterior e média falham devido a uma carga compressiva, sem perda da integridade dos elementos posteriores ou quando há uma ruptura da coluna posterior devido a uma falha em compressão, flexão lateral, ou rotação.

- Luxação e fratura-luxação são consideradas lesões raras, sendo que a mais comum de deslocamento da coluna torácica ou lombar é a fratura-luxação onde uma das vértebras é forçada para frente, sobre uma vértebra inferior seguinte. Este tipo de lesão só poderá ocorrer quando o processo articular estiver fraturado ou se ocorrer o 
deslocamento das articulações interfacetárias e o processo articular acavalgar. Os ligamentos posteriores estão sempre comprometidos e os dois corpos inferiores se acham fraturados próximo à superfície superior sendo que a linha de fratura é quase horizontal.

- Fraturas da apófise transversa são lesões praticamente limitadas à região lombar e pode envolver um único processo transverso, mas com maior freqüência dois ou mais são fraturados no mesmo lado.

- Fratura do sacro é rara e em geral a fratura é apenas um traço, sem deslocamento e quando ocorre deslocamento de fragmentos, há risco de lesão da cauda eqüina ou dos componentes nervosos do plexo sacral.

- Fratura do cóccix é uma lesão incomum e quando a fratura não se consolida, o cóccix deve ser extirpado.

Definição dos principais mecanismos de lesão:

- Lesão por flexão - ocorre um dobramento com orientação anterior seguido de queda na posição dobrada ou queda de um peso sobre o dorso quando a vítima estiver curvada causando uma fratura cuneiforme estável por compressão. A parte frontal do corpo vertebral se dobra, mas os ligamentos posteriores permanecem intactos.

- Lesão por flexão e rotação - Os principais danos aos ligamentos é constituído pela rotação. Em geral, a rotação está associada à flexão. Esta lesão é dada quando o complexo ligamentar posterior se rompe, enquanto que a coluna roda e sofre um corte anterior. A lesão óssea pode ocorrer simultaneamente; uma fatia de osso 
do topo de uma vértebra pode projetar-se para fora, sendo que as facetas posteriores podem sofrer fraturas.

- Lesão por extensão - as lesões por extensão lombar são menos comuns que as cervicais, mas pode ocorrer um dobramento com orientação posterior, que pode resultar em uma fratura da faceta interarticular. Esta lesão provem de uma flexão proveniente do sentido posterior e pode lesar o arco neural, mas não rompe os ligamentos posteriores.

- Lesão por compressão - este tipo de lesão só pode ser aplicada à porção reta da coluna. A coluna torácica não pode sofrer compressão, pois sempre apresenta cifose, mas a coluna cervical e lombar podem por estarem algumas vezes em posição reta.

- Lesão por cisalhamento - uma lesão se diz submetido ao cisalhamento quando nas secções transversais do osso o esforço solicitante é a força cortante.

\subsection{Fixador Interno}

Tipo de fratura mais sério, cujo risco de deslocamento posterior é dado em virtude da instabilidade é recomendado a fixação interna da região afetada da coluna sendo que a reabilitação do paciente pode ser acelerada, e que a incapacidade de longo período e muitas queixas às vezes implícitas no tratamento conservador podem ser evitadas. Geralmente a fixação é realizada com bastonetes de Harrington 
(HARRINGTON, 1962), presos nos processos articulatórios ou lâminas das vértebras apropriadas de modo que a força de extensão ou se necessário de compressão possa ser aplicada (Fig. 3 - A, B). Assim o segmento lesado ficará de maneira rígida, ao mesmo tempo em que a deformidade pode ser corrigida. Alguns recursos podem ser utilizados com a fixação como um retângulo de metal ou bastonetes de Luque, que são colocados posteriormente e presos com fio às lâminas de cada vértebra.

Ao nível da coluna lombar baixa, o emprego da fixação e artrodese monossegmentar apresenta seus maiores benefícios, pelas características anatômicas e importância desse segmento da coluna vertebral. Sua realização é também facilitada pela possibilidade da abordagem anterior retroperitoneal do segmento vertebral lesado, que tem menor morbidade quando comparada com a toracofrenolaparotomia (DEFINO et al., 1998).

A partir dos primeiros trabalhos de Harrington, divulgando seu método de fixação interna para a coluna, número cada vez maior de autores passou a utiliza-lo como relatos favoráveis, especialmente quanto à diminuição dos tempos de hospitalização e imobilização, facilitando os procedimentos de reabilitação (FILHO et al., 1998).

Dos trabalhos de Luque (LUQUE, 1982), sobre instrumentação segmentar na fixação da coluna, iniciou-se a associação dos dois métodos, Harrington e Luque, com a finalidade de obter maior 
estabilidade da coluna nos pacientes com fraturas instáveis e que possibilitasse a mobilização mais precoce dos mesmos.

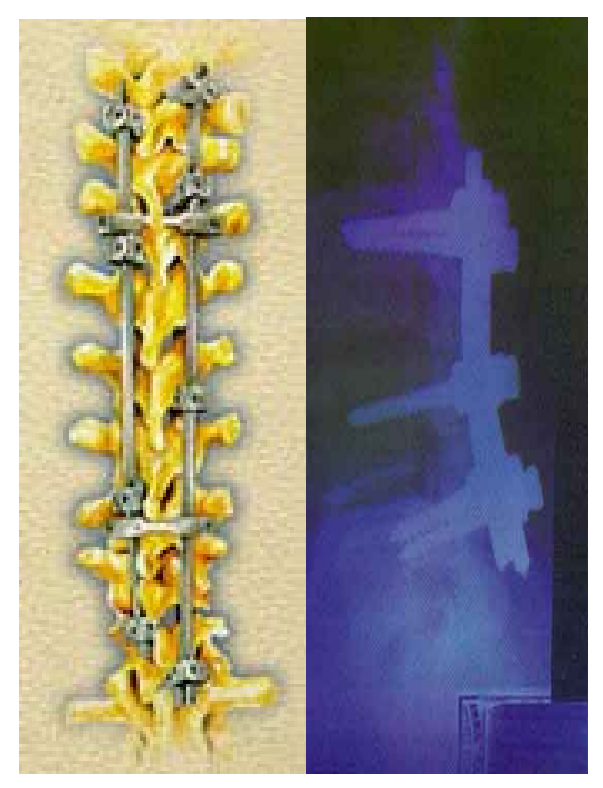

Fig. 3 - A, B - Fixações de fraturas.

As vantagens da fixação interna nas fraturas instáveis da coluna toracolombar (BRYANT \& SULLIVAN, 1983) são:

1) redução dos desvios e manutenção do alinhamento como forma de descompressão do canal vertebral;

2) restauração da estabilidade para promover consolidação e impedir piora do déficit neurológico;

3) prevenção de deformidade tardia;

4) baixo índice de pseudartrose;

5) mobilização precoce com menor morbidade, encurtando o período de reabilitação e o tempo de internação.

Os partidários de um tratamento conservador salientam que a fixação com freqüência falha, pois as lâminas ou hastes se desalojam 
dos processos espinhosos, a fratura se restitui e os implantes fazem pressão na pele, seguindo-se a sépis. Pode ser que lâminas mal aplicadas se desalojem, porém, nas mãos de um habilidoso cirurgião de coluna, a fixação é segura e, na sua totalidade, o método é mais satisfatório (APLEY, 1996).

Em virtude do grande número de métodos de fixação da coluna já desenvolvidos e outros ainda em desenvolvimento, acreditamos que o importante é o cirurgião optar pelo método ao qual estiver melhor habituado, estando ciente das vantagens, desvantagens e cuidados necessários para utilização do mesmo (FILHO, 1998).

\subsection{O Software Solid Edge}

O Solid Edge foi lançado em 1996, introduzindo inovações na interface do usuário e na operação, que definem o paradigma de facilidade de uso do projeto em 3D. Cada nova versão do software tem incluído melhorias significativas visando facilidades no modelamento de sólido e mais eficiência no processo de projeto.

É um sistema CAD parametrizado, desenvolvido para engenheiros mecânicos, onde se pode construir sólidos inteligentes, montagens com grande número de componentes, elementos normalizados baseados em cálculos de engenharia e realizar simulações de movimentos. 
Além disto, este software foi desenvolvido como um aplicativo baseado em Windows rodando em microcomputadores baseados em processadores de baixo custo, não necessitando de grandes investimentos para ter acesso aos recursos do projeto 3D.

A incorporação de diversos tipos de ferramentas passou a atender as necessidades dos profissionais de projeto que utilizam atualmente $\mathrm{CAD} 2 \mathrm{D}$, pois ele pode ler e salvar arquivos em todos os formatos populares de CAD 2D, e pode também utilizar informações diretamente no processo de modelamento do sólido.

O modelamento do sólido é baseado em "features" (características específicas como furo, eixo, cavidade, etc.) e "paramétricos" (sub-rotina paramétrica; sub-rotina que usa parâmetros para definir seus limites ou ações) transformando-o em um método de projeto bastante intuitivo com a utilização de termos, conceitos e comandos de entidades primitivas de desenho utilizadas em sistema CAD 2D tendo como resultado projetos mais rápidos e mais precisos.

Um programa paramétrico de CAD difere basicamente de um outro, tradicional, em um aspecto chave. Enquanto que nos CADs clássicos o desenho permanece na memória do computador como uma série de relações de pontos - coordenadas, sentido e direção - em programas vetoriais, ou como um grupo de pixels em programas de renderização e tratamento de imagens, em um programa paramétrico a informação visual é parte da informação disponível no banco de dados, 
ou seja, uma representação da informação como um objeto, na tela do computador.

Cada elemento do desenho (paredes, portas, janelas, etc.) é tratado como um "objeto", que não é definido mais apenas por suas coordenadas espaciais ( $x, y$ e $z$ ), mas também por seus parâmetros sejam estes gráficos ou funcionais.

Através dos modelos 3D são construídos os desenhos de vistas e cortes. Desenhos de conjunto e vista explodida são criados à partir da montagem. Do ponto de vista do projetista os comandos foram desenvolvidos com a finalidade de acelerar o máximo o desenvolvimento de produtos.

A geração mais rápida de desenhos com modelamento sólido 3D pode ser desenvolvido, pois o software elimina a necessidade de criação de desenhos vista por vista a partir de elementos $2 \mathrm{D}$, assim 0 modelamento sólido pode ser feito simplesmente selecionando vistas do modelo sólido que gerará automaticamente os desenhos das vistas planas simplificando a criação de vistas "ortográficas", "auxiliares", "detalhes" e "isométricas".

O software segue normas internacionais para modelagem 3D e representação 2D de projetos específicos ou segue a definição do próprio usuário.

Com o modelo sólido 3D de peças e montagens consegue-se ver exatamente o que é o projeto e como ele se enquadra na estrutura da montagem antes da construção de uma peça e permite que os 
engenheiros avaliem visualmente os ajustes, interferências e ambiente de trabalho com maior precisão e de forma rápida (Fig. 4). Com a visualização mais completa e melhor definição geométrica que o modelamento 3D permite, reduz-se significativamente o número de projetos comparando-se com as técnicas de projeto 2D e assim gera uma redução de erros, tempo, custo, reengenharia, pedidos de alteração de engenharia, e ciclos iterativos de análise, prototipagem, ferramentaria, engenharia de fábrica, e outras atividades do desenvolvimento de peças.

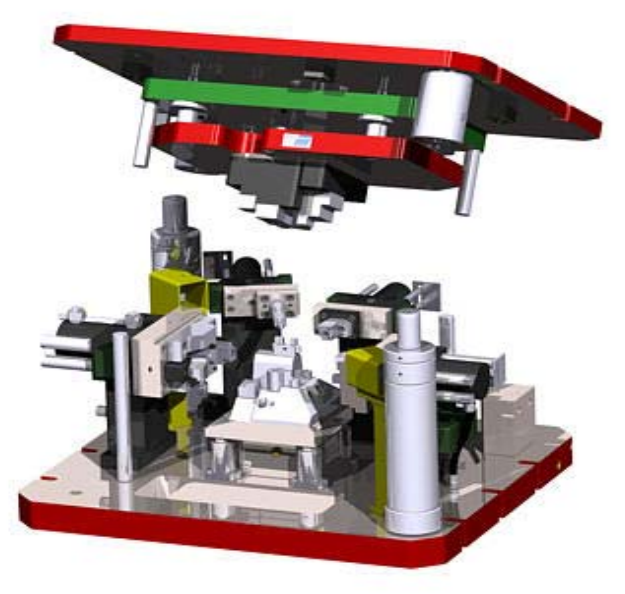

Fig. 4 - Modelagem no Solid Edge - Solid Edge Copyright $^{\odot}$ 1996-2001। UGS.

Com uma descrição mais precisa da geometria do projeto os modelos 3D são mais superiores aos desenhos 2D para a comunicação de informações do projeto para as funções subseqüentes de engenharia e manufatura. Os modelos contêm informações de superfície e volume necessário para uma analise de engenharia e os dados gerados com o 
modelamento podem ser aplicados muito além das áreas de projeto, engenharia e manufatura.

O trabalho com o Solid Edge é baseado de acordo com: comando, plano, desenho 2D, sentido, extensão e finalização (Fig. 5).

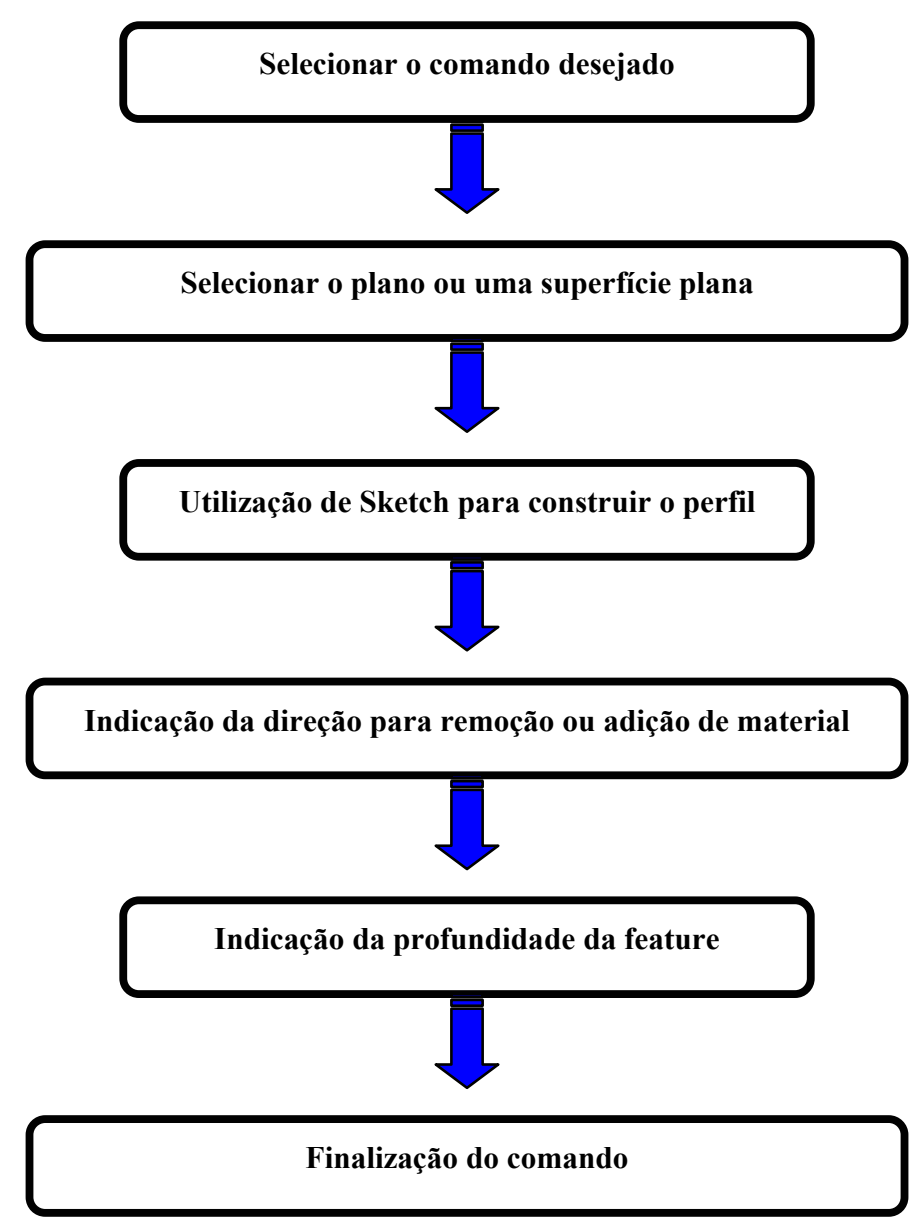

Fig. 5 - Fases do projeto. 


\subsection{O Software ANSYS ${ }^{\circledR}$}

O ANSYS $^{\circledR}$ consiste de várias ferramentas para análise de projetos baseada no método de elementos finitos a fim de resolver problemas de análise das diversas áreas de engenharia.

Os usuários do software ANSYS $^{\circledR}$ são as indústrias (automobilísticas, aeronáutica, térmica, eletro-eletrônico), empresas de engenharia (construtoras, consultoria, projetos), órgãos governamentais (agências espaciais, militares), universidades.

Este software possui uma interface gráfica amigável e bem organizada, facilitando ao usuário acesso às funções, comandos, documentações e materiais de referência além de oferecer uma ajuda "on-line" com toda a documentação do software e um sistema de ajuda, baseada em hipertexto. A interface gráfica permite customizar as funções, comandos e rotinas através da barra de ferramentas além de sintetizar em botões as funções mais utilizadas pelo usuário.

O usuário tem quatro métodos de operações: menus, caixas de diálogos, barras de ferramentas e entrada direta de comandos.

A interatividade gráfica do software é total, ou seja, tanto a nível de processamento como a nível de pós-processamento e poderá ser visualizado através de gráficos, pois o software suporta alta resolução e mais de 256 cores.

O ANSYS ${ }^{\circledR}$ possui um pré-processador, um processador de soluções e dois pós-processadores, um geral e outro de resultados no 
tempo. O primeiro pós-processador exibe gráficos de qualquer tipo de análise independente do tempo como temperatura, tensões ou fluxo de fluidos ao redor do modelo. O segundo permite analisar dados no tempo, como freqüências, transientes ou deslocamentos em função do tempo.

A linguagem do pacote é parametrizada - APDL (ANSYS Parametric Desing Language) permitindo a automatização do processo através de um analisador inteligente ou seja através de um sofisticado sistema de entrada de dados, dando ao usuário o controle total de qualquer parâmetro do projeto como: dimensões, materiais, cargas, restrições e otimizações. A APDL permite também a definição de macros e a utilização de sub-rotinas criadas pelo próprio usuário como a linguagem FORTRAN e C, que podem ser linkados com o código do ANSYS $^{\circledR}$ podendo melhorar as capacidades criando comandos, elementos, equações, materiais com comportamentos específicos ou critérios de falhas diferentes.

O software permite a utilização de alguns modelos CAD, através de transferência ou importação como: STEP, ACIS ${ }^{\circledR}$ (SAT), IGES, Computervision/CADDS ${ }^{\circledR}$, Pro/ENGINEER $^{\circledR}$ e Unigraphics ${ }^{\circledR}$. Além disso, os arquivos criados no formato ANSYS ${ }^{\circledR}$ podem ser utilizados por qualquer produto da família ANSYS ${ }^{\circledR}$ e em qualquer plataforma ou seja sua portabilidade é total.

Qualquer tipo de problema das diferentes áreas de engenharia existentes, da civil até a eletrônica, passando pela mecânica, 
biomecânica, química, metalúrgica, pode ser aplicado virtualmente pelo ANSYS $^{\circledR}$.

Todos os tipos de carregamento podem ser definidos, para uma análise de tensões, deslocamentos e deformações e ainda definir o tipo de propriedade do material. O programa pode definir também as acelerações necessárias para contrabalançar as cargas aplicadas.

O pacote é capaz também de resolver problemas que envolvam não-linearidade (possui o seu próprio comportamento nãolinear, independente dos outros elementos), seja ela geométrica, material, ou dos elementos.

Com elementos não-lineares é possível resolver problemas como: superfície de contato, interfaces, sólidos reforçados (concreto, rochas, compósitos), molas e amortecedores não-lineares, membros que trabalham apenas com tensão ou compressão, conchas ou carapaças (de animais) com opções de dobramento, elementos combinados (massa, amortecedor, guias), elementos de controle (por exemplo, binários ou lógicos) e outras singularidades.

A análise dinâmica linear e não-linear pode ser resolvida pelo software como: cargas alternadas (máquinas rotativas), cargas súbitas (impactos ou explosões), forças aleatórias (terremotos) e qualquer tipo de carga transitória (cargas móveis sobre um ponto). Os modelos de análise são: transiente, modal, harmônica, espectral e vibrações aleatórias.

O programa utiliza três modelos básicos para transferência de calor: condução, convecção (livre e forçada) e radiação. Operando com 
os parâmetros de calor específico, entalpia, condutividade térmica, coeficiente de convecção (ou de filme) e emissividade.

As capacidades de análise de transferência de calor do ANSYS ${ }^{\circledR}$ são: regime permanente, transitório, mudança de fases e térmica-estrutural.

A análise em mecânica dos fluídos utiliza-se das técnicas computacionais de dinâmica de fluídos. Assim pode-se realizar a análise da vazão, pressão ou a distribuição de temperatura do escoamento líquido ou gasoso em tubos ou em sistemas diferentes acoplados.

O escoamento pode ser analisado tanto no regime permanente quanto nos transitórios, além do equacionamento poder ser linear ou não-linear dependendo do problema. Estão disponíveis vários tipos de análise para as técnicas computacionais de dinâmica dos fluídos, incluindo: escoamento laminar, escoamento turbulento, térmico-fluido, fluido-estrutural, escoamento compressível e escoamento em tubos.

O usuário também pode realizar modelagem de sólidos no software, pois este possui primitivos geométricos como esferas ou prismas e através de definições de pontos, linhas, áreas e volumes. Poderá também ser feita conversão de arquivos IGES de definição de geometrias, no caso de modelos de formas mais complexas.

A especificação de arquivo IGES estabelece informações da estrutura para serem utilizada em representações digitais e comunicação de dados entre outros produtos CAD/CAM. 
O formato de arquivo definido por esta especificação trata a definição do produto como um arquivo de entidades. Cada entidade é representada em um formato de aplicação-independente, para o qual a representação de um sistema CAD/CAM específico pode ser traçada. As representações de entidade providas nesta especificação incluem formas atualmente comum aos sistemas de CAD/CAM e formas que apóiam as tecnologias de sistema que emergem atualmente.

\subsection{O Método dos Elementos Finitos}

A análise dos elementos finitos (FEA) é uma técnica númerica de computação usada para calcular a força e o comportamento de estruturas em engenharia. A deflexão pequena, ou em grande escala sob

o carregamento ou deslocamento aplicado, a tensão, a vibração, o comportamento da formação de ondas, a deformação elástica e outros fenômenos podem ser também calculadas pela FEA.

O método dos elementos finitos (MEF) teve grande participação em projetos desenvolvidos pela NASA e na resolução de problemas de análise estrutural da industria aeronáutica.

Esse método foi desenvolvido pelo matemático Courant em 1943, com proposta da divisão da área contínua em regiões triangulares, passo a passo. 
O computador é requerido por causa do número astronômico dos cálculos necessários para uma analise de estrutura grande e devido a potência e o custo baixo de computadores.

A descrição para o método dos elementos finitos (MEF) pode ser dada como uma solução de um problema complexo através de subdivisões, utilizando as técnicas matemáticas e o uso do computador, fornecendo soluções numéricas apropriadas das equações diferenciais (ZAGOTTIS, 1975).

No método dos elementos finitos uma estrutura é quebrada em pequenos blocos ou elementos simples pequenos (Fig. 6). $\mathrm{O}$ comportamento de um elemento individual poderá ser mostrado através de um conjunto relativamente simples de equações onde a adição do jogo dos elementos para a construção da estrutura inteira é feita com a soma das equações que descrevem os comportamentos dos elementos individuais gerando assim um conjunto extremamente grande de equações que descrevem o comportamento da estrutura inteira. 0 computador poderá resolver este grande conjunto de equações simultâneas onde o resultado será o comportamento dos elementos individuais. Com o resultado pode-se analisar a tensão e a deflexão de todas as partes da estrutura e fazer assim uma comparação dos valores obtidos com os valores permitidos.

O termo "elemento finito" distingue a técnica do uso "dos elementos diferenciais infinitesimal" usados no cálculo, em equações diferenciais e em equações diferenciais parciais. Este método também é 
distinguido das equações de diferenças finitas, para que as etapas onde o espaço é dividido sejam finitas no tamanho.

$\mathrm{Na}$ área Médica atua especificamente na Ortopedia e Biomecânica tornando-se uma ferramenta importante para estudos, pesquisas e simulações de problemas mecânicos em ossos (SHIMANO, 1994). O método dos elementos finitos (MEF) é um método de simulação que proporciona o dimensionamento e levanta as propriedades geométricas e mecânicas da região óssea.

A análise finita do elemento é uma maneira de tratar estruturas que são mais complexas do que pode ser tratada analíticamente usando equações diferencias parciais.

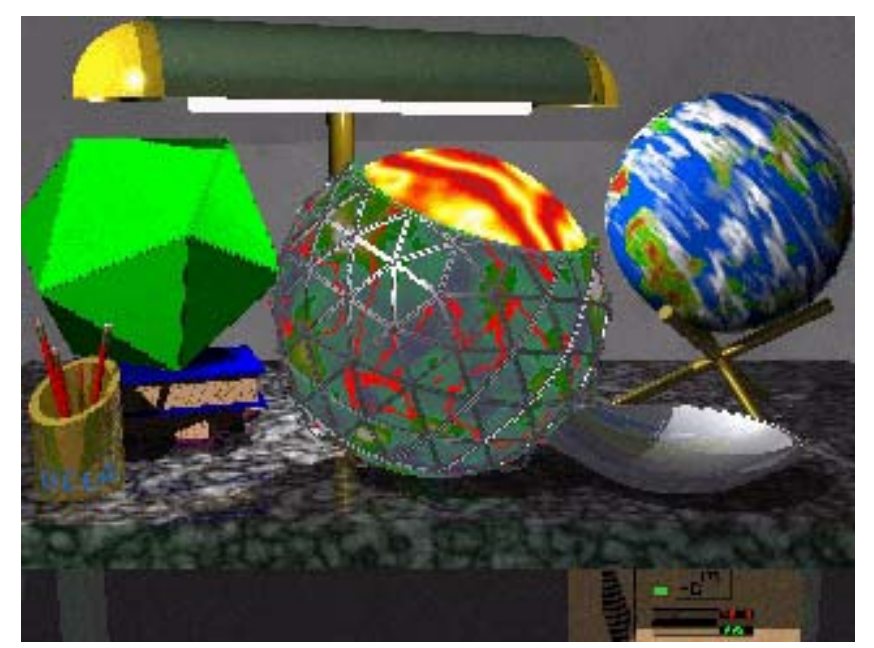

Fig. 6 - Exemplo da utilização de Elementos Finitos.

Na ausência da análise finita do elemento (ou de outra análise numérica), o desenvolvimento das estruturas deve ser baseado em cálculos a mão. As mudanças significativas nos projetos envolvem riscos 
além de ser requerido a construção de protótipos para os testes de campo. Com análise finita do elemento, o peso de um projeto pode ser minimizado, e pode haver uma redução no número de protótipos construídos.

A análise finita do elemento é feita principalmente com softwares comerciais. Estes pacotes podem incluir o pré-processamento que pode criar a geometria da estrutura, ou importá-la de um outro software CAD. Os softwares FEA possuem módulos para analisar o problema definido e para rever os resultados da análise através de formulários impressos e em resultados traçados tais como mapas do contorno da tensão, conjunto de deflexão e gráficos de parâmetros de saída.

Os nós e os elementos são requeridos sempre como a parte da definição da geometria em todos os modelos de elementos finitos. Toda ação ocorre em posição do nó. Os nós (pontos ou junções de grade) junto com elementos dão forma às entidades fundamentais usadas na análise finita do elemento. Alguns resultados básicos são diretamente computados e indicados ou relatados em nós e outros resultados são segurados em uma base do elemento. Os nós são definidos por dois parâmetros: sua posição no espaço e nos elementos a que são unidos. 0 sistema de coordenadas usado para identificar a posição de um nó é chamado de sistema de definição. 


\subsection{Objetivo}

Este trabalho foi desenvolvido com os seguintes objetivos:

- Modelar o fixador interno de coluna (corpo de prova) em um software CAD;

- Analisar através da simulação computadorizada o comportamento da montagem dos fixadores internos de coluna vertebral constituídos em titânio (liga) e alumínio (liga) diante de ensaios de flexocompressão e flexão lateral;

- Verificar as deformações ocorridas nos fixadores a cada aplicação de carga;

- Localizar o ponto de maior e menor tensão durante os ensaios;

- Verificar os diferentes níveis de tensões através do degrade de cores do simulador;

- Realizar novos ensaios a partir do mesmo modelo sem a necessidade da construção de novos corpos de prova;

- Alterar característica e propriedade do corpo de prova sem a intervenção do fabricante. 


\section{MATERIAL E MÉTODO}

\subsection{MODELO EXPERIMENTAL}

O material do sistema de Fixação Interna (porcas, parafusos, haste e sapatas) é de Titânio (liga) ou Alumínio (liga) (ANEXO).

Para as simulações computadorizadas foi utilizada a montagem feita na prática clínica (Fig. 7).

1 - Utilização de parafusos maciços;

2 - Utilização de haste maciça;

3 - Utilização de sapatas na fixação da haste;

4 - Utilização de roscas;

5 - Utilização da montagem dos parafusos, haste, sapatas, roscas;

6 - Avaliação do sistema de fixação.

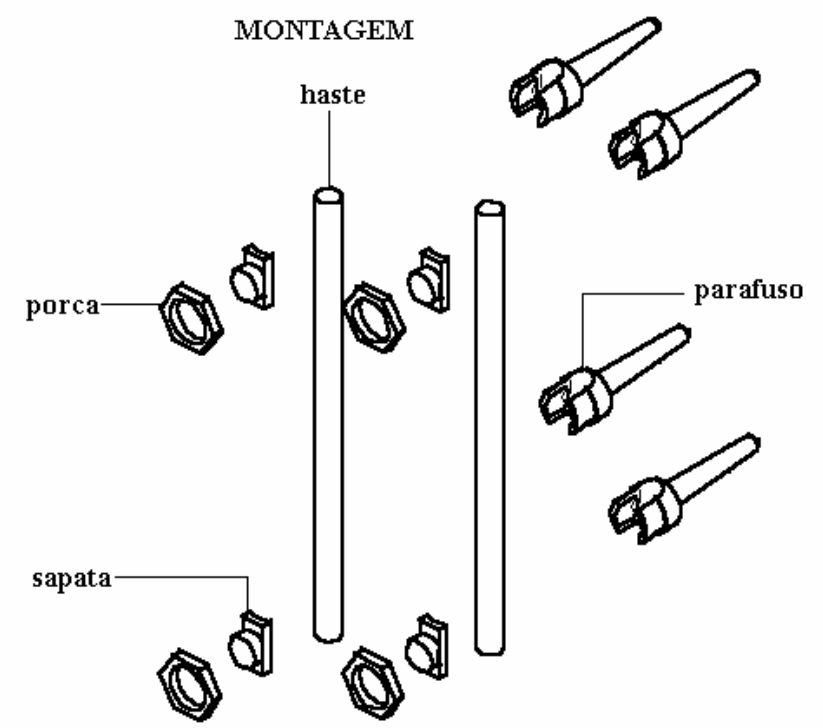

Fig. 7 - Montagem dos componentes do fixador 


\subsection{VALIDAÇÃO DO MODELO PROPOSTO}

Para validação, foram realizados ensaios mecânicos de flexocompressão (Fig. 8) e flexão lateral (Fig. 9) no modelo do fixador a fim de verificar os resultados.

O modelo experimental tem como finalidade avaliar o efeito de cargas sobre o fixador interno de coluna, respeitando a geometria da montagem (forma, ângulos e distâncias) e as características biomecânicas locais.

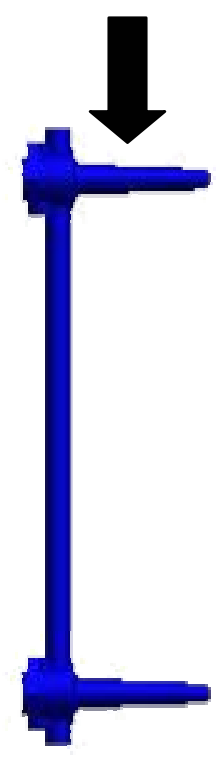

Ponto de aplicação das cargas

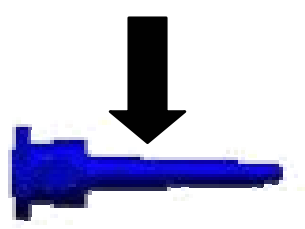

Fig. 8 - Aplicação de uma carga de flexo-compressão 

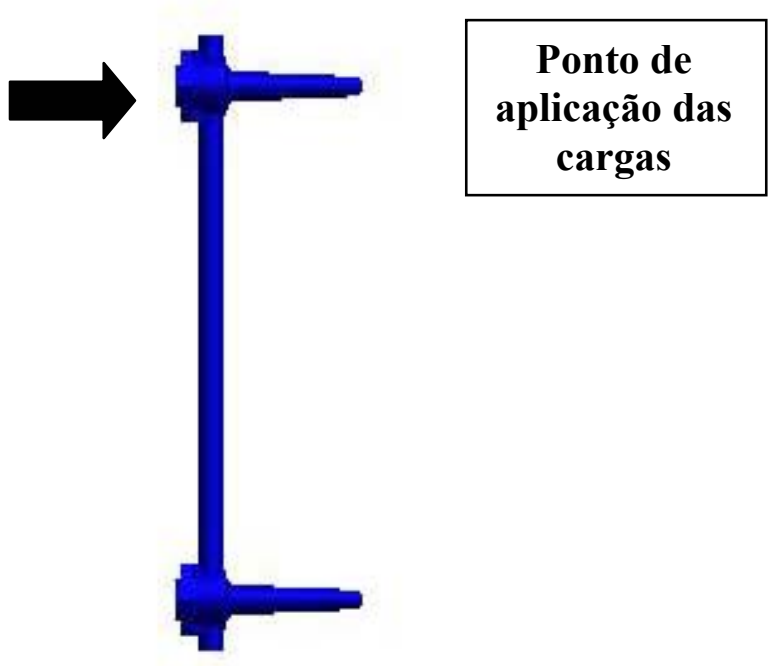

Fig. 9 - Aplicação de uma carga de flexão lateral

\subsection{MODELAGEM}

A modelagem das peças do fixador interno de coluna (parafusos, haste, sapatas e porcas) foi feita no software CAD Solid Edge $^{\odot}$. Este software de modelagem de sólidos é muito utilizado por engenheiros por trabalhar com "features", ser "parametrizado" e possuir uma interface amigável (Fig. 10). 


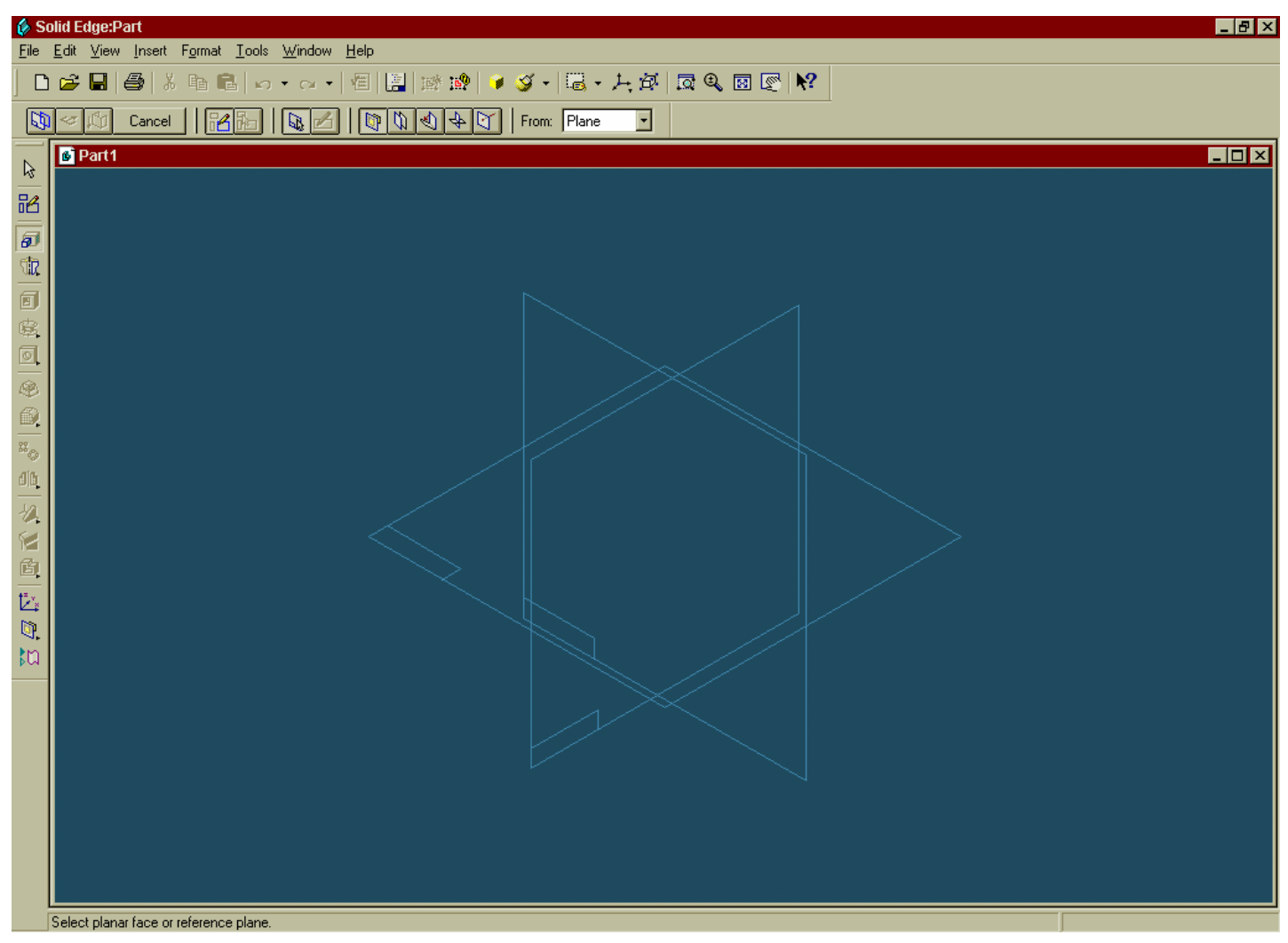

Fig. 10 - Interface gráfica do software Solid Edge

\subsubsection{PROCEDIMENTO PARA MODELAGEM DE UMA DAS PEÇAS}

Abaixo menciona-se a seqüência a ser seguida para a modelagem de uma das peças do fixador:

1- Seleção do eixo para a construção da haste (Fig. 11-A, B);

2- Realização da "protusion" (construção de uma peça através do perfil) escolhendo a ferramenta necessária (Fig. 12);

3- Passar as cotas da peça (Fig. 13 e 15);

4- Clicar em Finish para o término do perfil (Fig. 14);

5- Resultado obtido em "Wireframe Outline" (modo exibição aramado) (Fig. 16); 
6- Resultado obtido em "Shade" dando uma visão real da peça (Fig. 17);

7- Finish para o término da peça Fig. 18).
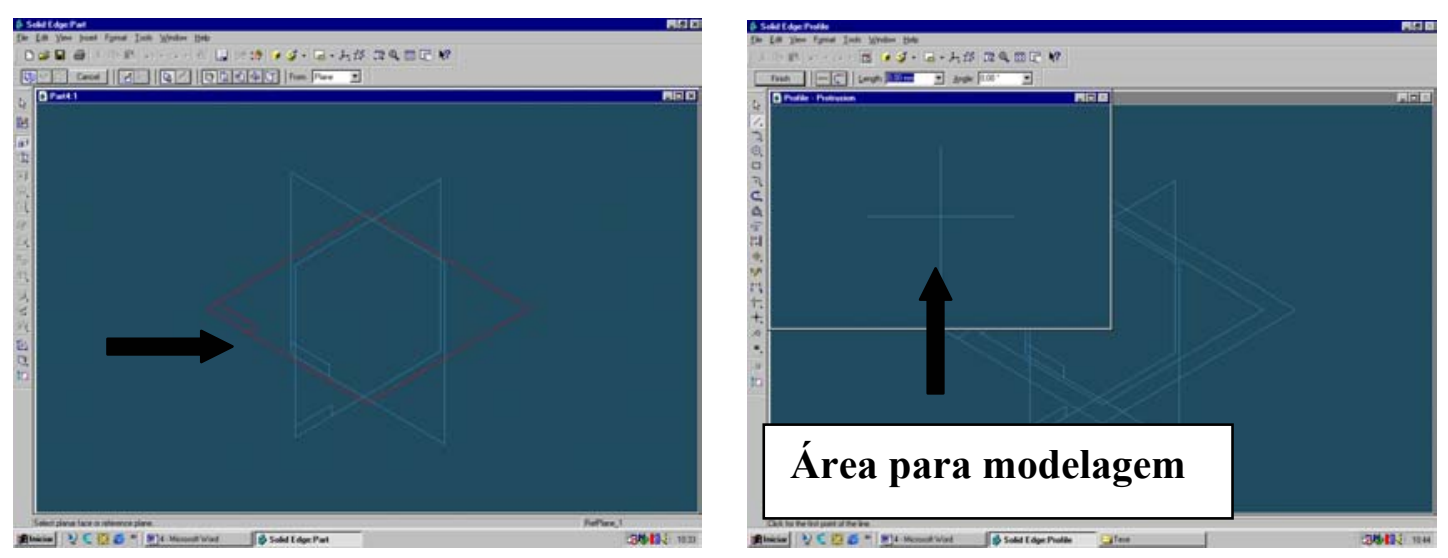

Fig. 11-(A), (B) Seleção do eixo de modelagem

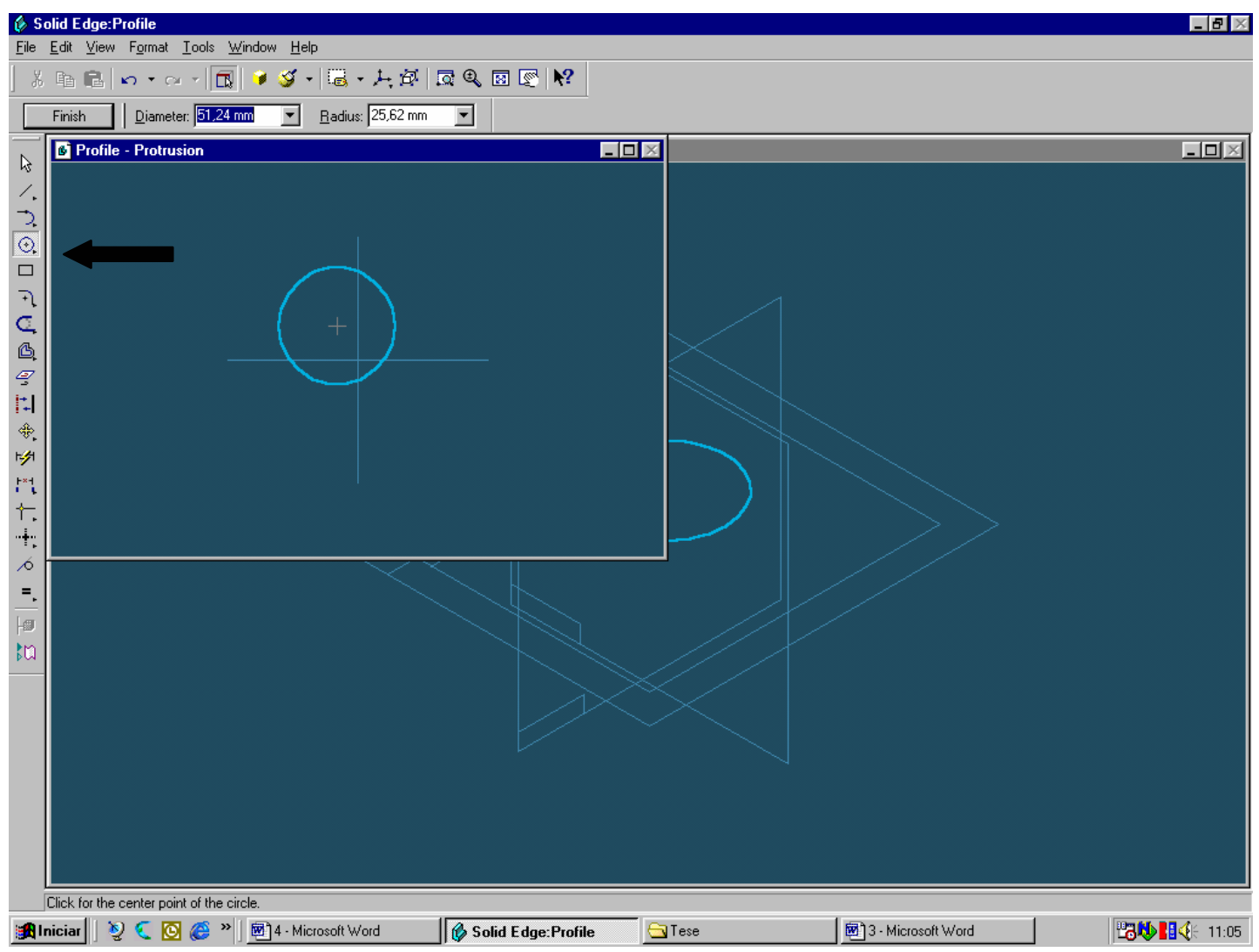

Fig. 12 - Escolha da ferramenta para "Protusion" 


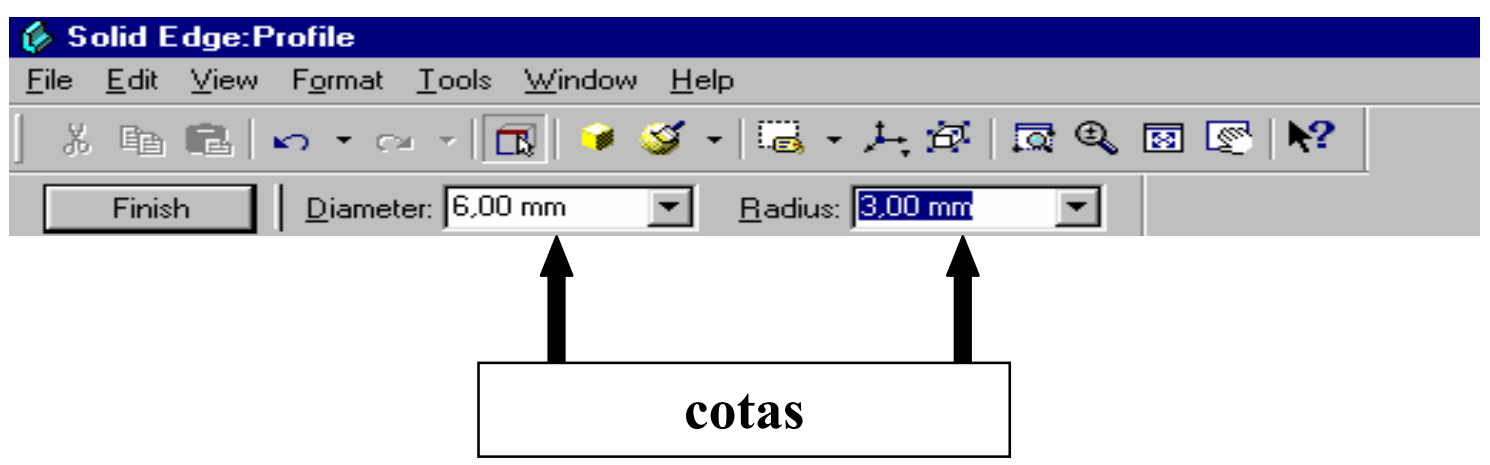

Fig. 13 - Diâmetro e raio da haste

\section{Solid Edge:Profile}

File Endit View Format Iools Window Help

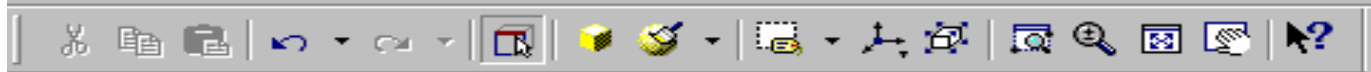

Finish 1 Diameter: $6.00 \mathrm{~mm} \quad$ Radius: $3.00 \mathrm{~mm}$

Fig. 14 - Término do perfil da haste

\section{Solid Edge:Part}

File Édit View Insert Format Iools Window $\underline{H}$ elp

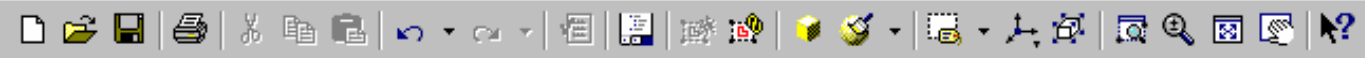

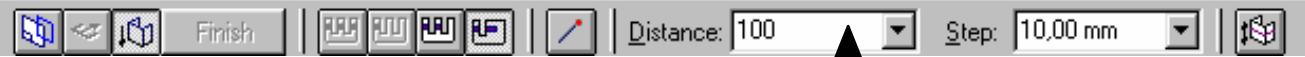

Fig. 15 - Altura da haste do fixador 


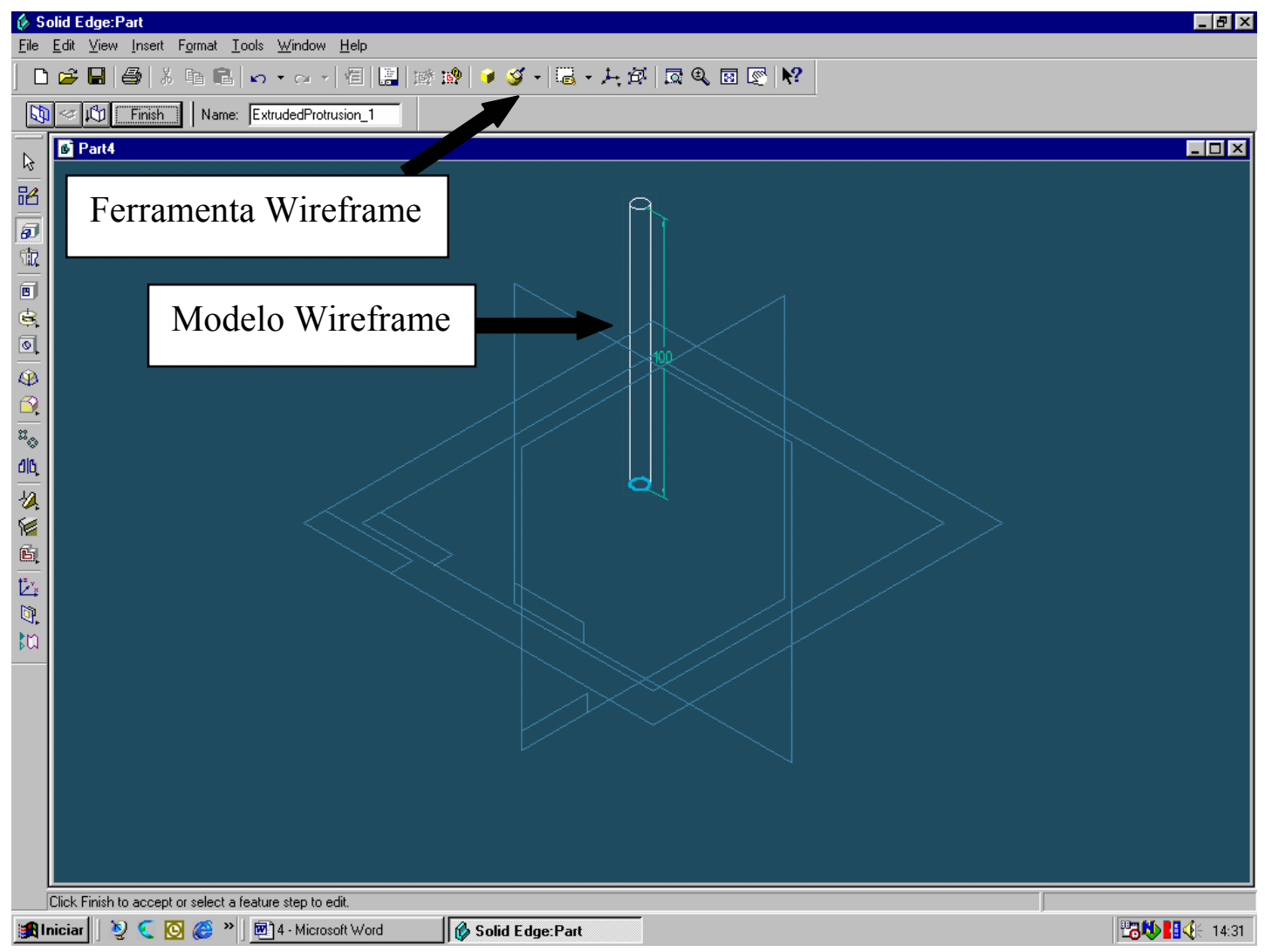

Fig. 16 - Vista da peça em "Wireframe Outline" 


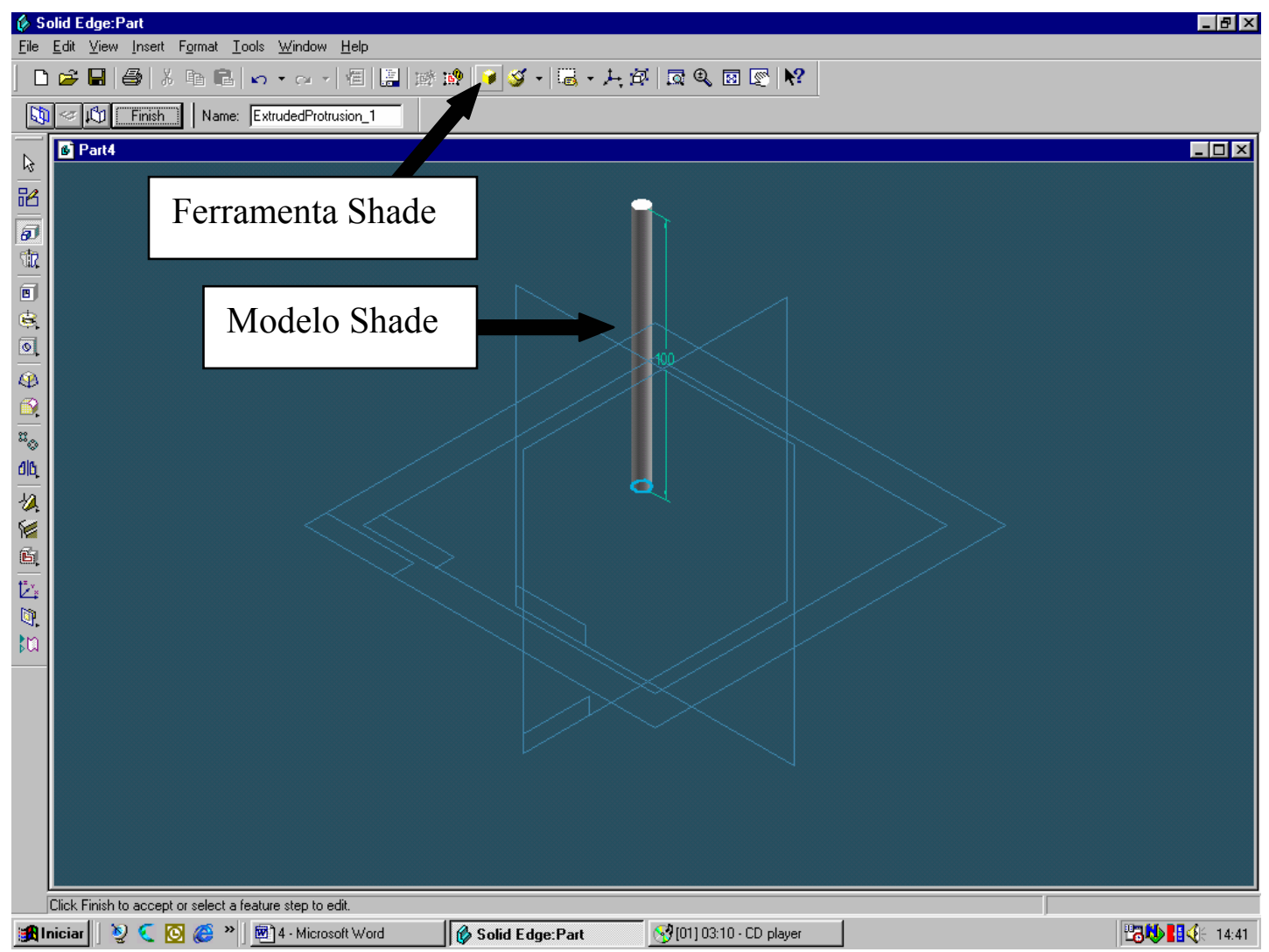

Fig. 17 - Resultado da haste no modo "Shade"

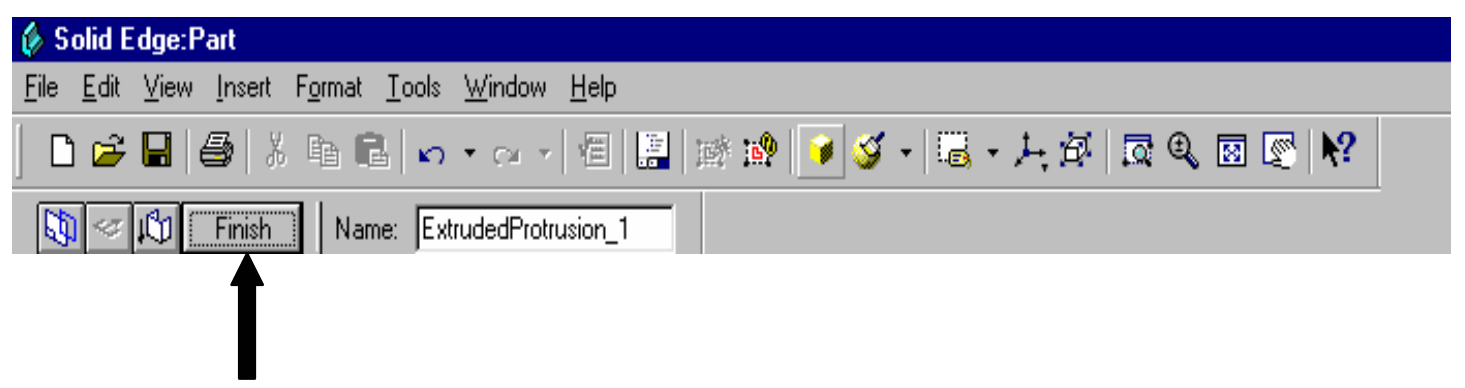

Fig. 18 - Término da haste do fixador interno de coluna

Feita a modelagem da haste do fixador interno de coluna no Software Solid Edge ${ }^{\odot}$ o arquivo foi salvo com a extensão IGES e exportado para o Software ANSYS $^{\circledR}$ onde foram realizadas as 
simulações dos fixadores internos (liga de titânio e liga de alumínio) utilizando o método dos elementos finitos (Fig. 19).

O Software Solid Edge ${ }^{\odot}$ possui uma interface muito amigável e parecida com a do Windows; sendo assim os comandos básicos para salvar um arquivo são os utilizados nos aplicativos da Microsoft.

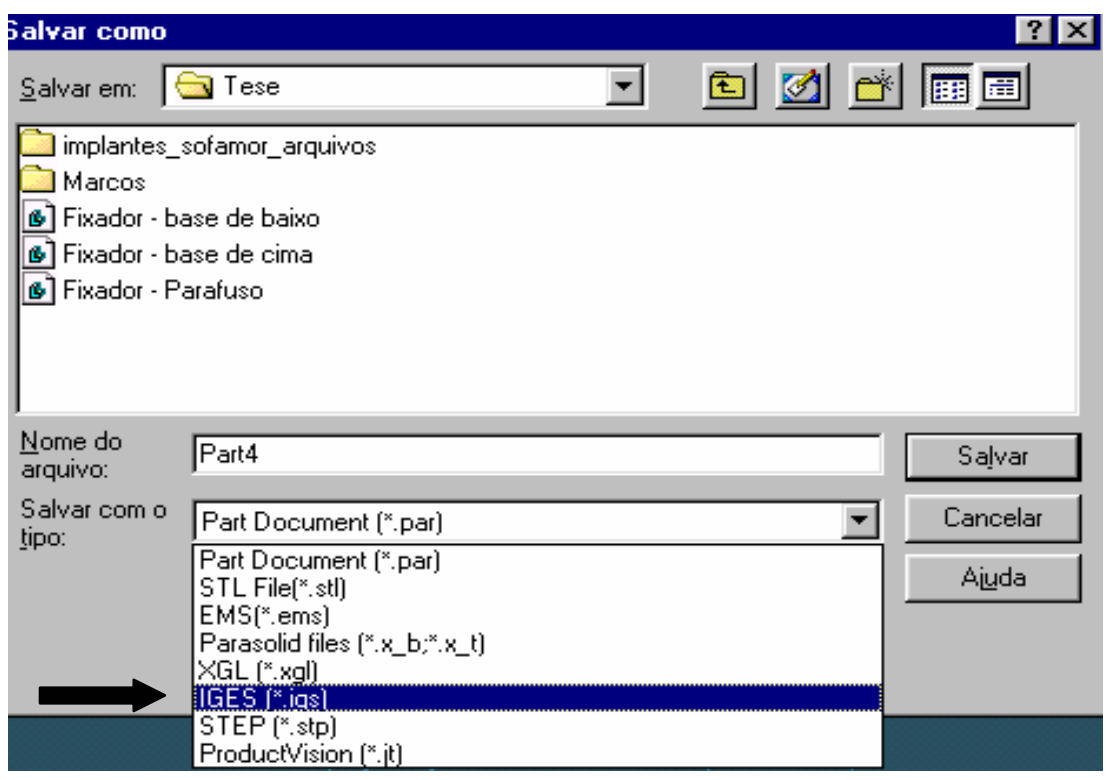

Fig. 19 - Haste do fixador salvo com a extensão IGES

\subsection{UTILIZAÇÃO DO SOFTWARE ANSYS ${ }^{\circledR}$}

Para a realização das simulações foram necessárias algumas propriedades dos materiais titânio (liga) e alumínio (liga) (TABELA 1).

O titânio é um metal branco prateado, leve, resistente, usinável, usado em ligas especiais. É usado comercialmente puro (99,75\%) e suas propriedades mecânicas são determinadas em grande parte pela microcomposição. Desde o início tem sido utilizada uma composição exatamente identificável, ou seja: Fe, 0,05\%, N, 0,03\%, C, 
0,05\% e H, 0,012\%. Se diminuíssemos, por exemplo, o conteúdo de Fe até $0,005 \%$ diminuiria consideravelmente a resistência mecânica do metal, entretanto, se aumentarmos o conteúdo de Fe acima de 0,05\% aumentam os riscos de corrosão. Pequenas alterações na liga podem conduzir a alterações na tolerância do material por parte do osso do hospedeiro.

O titânio puro ao entrar em contato com ar se recobre instantaneamente de uma capa de óxido. As propriedades da capa de óxido de superfície dependem das condições sob as quais foi realizada a oxidação. O controle dos diferentes passos de preparação do titânio (pressão, lubrificantes, velocidade, tipo de instrumentos usados na usinagem), e posterior manipulação (limpeza por ultra-som, esterilização, contatos com outros metais ou contaminantes) asseguram ou não uma superfície biocompatível.

A interação química de fixadores de titânio (liga) é determinada pelos óxidos de superfície e não pelas propriedades químicas do metal. Alguns fatores que fazem o titânio particularmente compatível: 1) se recobre de uma capa de óxidos inertes, muito estáveis e resistentes à corrosão; 2) os óxidos de titânio possuem uma alta constante dielétrica; 3) combina a excelente biocompatibilidade de superfície com as propriedades mecânicas favoráveis do núcleo de metal; 4) material resistente e ao mesmo tempo leve.

O alumínio não aparecia na forma pura assim foi utilizado a liga de duro alumínio que nas formulações utilizadas na atualidade é um material leve, de manipulação relativamente fácil e bom condutor de 
calor. Estudos demonstraram desvantagem na utilização dos fixadores internos de coluna de alumínio, pois demonstrou níveis plasmáticos elevados de alumínio em pacientes.

Tabela 1 - Propriedades dos materiais

\begin{tabular}{|l|c|c|}
\hline \multicolumn{3}{|c|}{ TITÂNIO (liga) } \\
\hline Módulo de elasticidade & $116 \mathrm{GPa}$ & $116 * 10^{3} \mathrm{~N} / \mathrm{mm}^{2}$ \\
\hline Coeficiente de Poisson & 0,34 & 0,34 \\
\hline \multicolumn{3}{|c|}{ ALUMíNIO (liga) } \\
\hline Módulo de elasticidade & $69 \mathrm{GPa}$ & $69 * 10^{3} \mathrm{~N} / \mathrm{mm}^{2}$ \\
\hline Coeficiente de Poisson & 0,38 & 0,38 \\
\hline
\end{tabular}

A biblioteca de elementos do ANSYS contém mais de 100 tipos diferentes de elementos. Cada tipo de elemento tem um número original e um prefixo que identifique a categoria do elemento.

A geração da malha do fixador interno de coluna foi feito com a utilização de elementos do tipo sólido estrutural tetraedro 92 3D 10 nós (Fig. 20). O sólido 92 tem comportamento de deslocamento quadrático, usado para modelar malhas irregulares e é encontrado na caixa de elementos contidos no ANSYS ${ }^{\circledR}$. 
O elemento está definido por dez nós que têm três graus de liberdade em cada nó. O elemento também tem plasticidade, deflexão grande e capacidade de tensão.

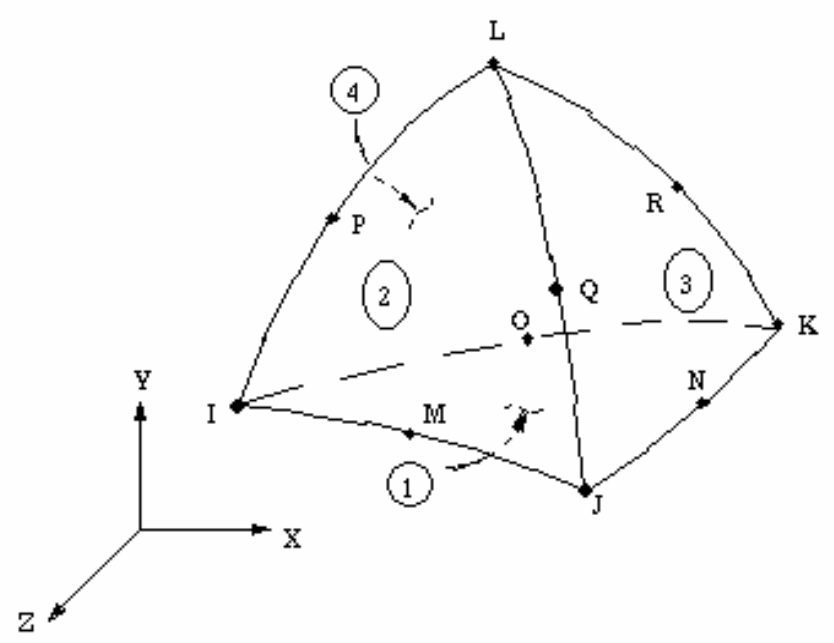

Fig. 20 - Sólido estrutural tetraedro 92 3D 10 nós

Ao lado dos nós, os dados do elemento contribuem para as propriedades "ortotrópicas" dos materiais. O material "ortotrópico" corresponde às direções das coordenadas dos elementos.

Num material ortotrópico existem 3 planos ortogonais de simetria material. Então, os planos $x_{1} x_{2}, x_{1} x_{3}$ e $x_{2} \times 3$ são planos de simetria material pelo qual qualquer tensão simétrica relativamente a esses planos só pode provocar deformações simétricas.

De forma idêntica qualquer tensão anti-simétrica relativamente a esses planos só pode provocar deformações anti-simétricas.

Pressões podem contribuir como cargas de superfície nas faces dos elementos, como mostrados pelos números circulados na figura anterior. 
Pressões positivas no elemento, temperaturas e fluxos podem contribuir quando o corpo do elemento carrega os nós.

As direções de tensão do elemento são paralelas ao sistema de coordenadas do elemento. As produções de tensões da superfície estão no sistema de coordenada da mesma e são avaliadas para qualquer face. O sistema de coordenadas para face JIK é mostrado na Figura 21. Os outros sistemas de coordenadas da superfície seguem orientações semelhantes como indicado pela pressão da face nodal descrita. A tensão da superfície só seria válida se as condições fossem descritas em uma seção conhecida.

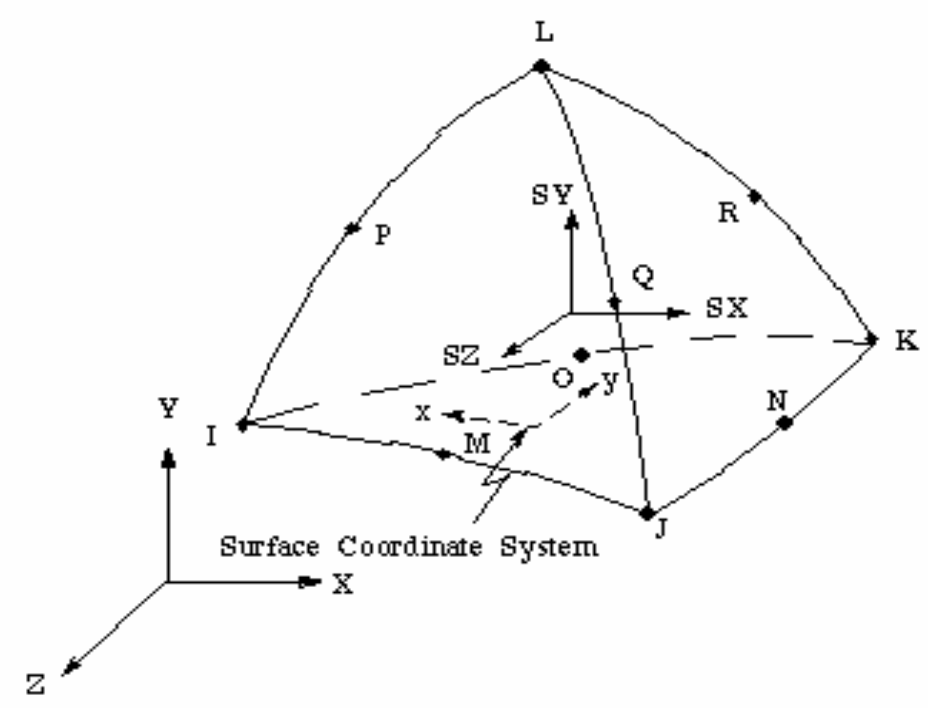

Fig. 21 - Direções das tensões e produções de tensões

O elemento não deve ter um volume zero para a análise. As faces do elemento podem aparecer numeradas como mostrados na Figura 20 ou representado pelo nó $\mathrm{L}$ como a superfície IJK. Uma 
extremidade com um nó afastado insinua que o deslocamento varia linearmente, no lugar da parabólica, ao longo daquela extremidade.

O fixador interno de coluna recebeu elementos tetraedros formando um total de 26.100 nós e 16.223 elementos distribuídos em um volume (Fig.22). Este total de nós e elementos foram definidos a partir da seleção geral da peça e a geração automática através de um dos menus oferecidos pelo ANSYS ${ }^{\circledR}$.

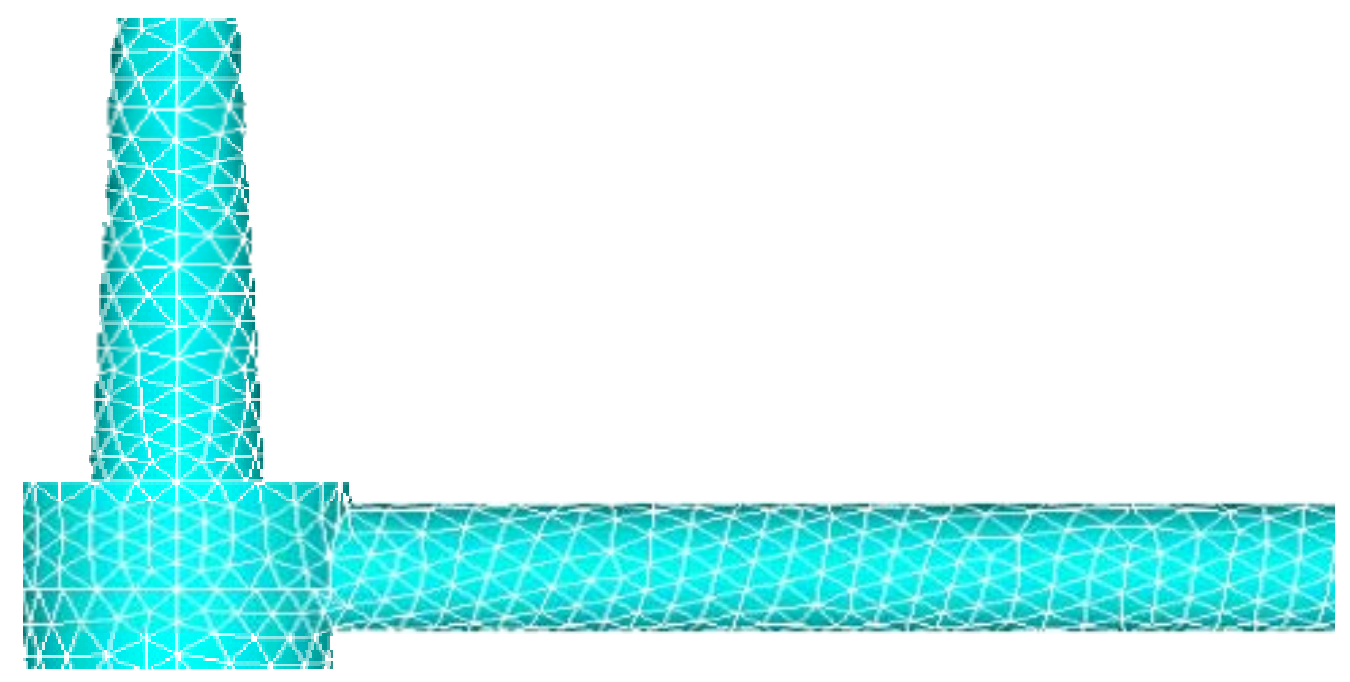

Fig. 22 - Elementos tetraedros do fixador

Para chegar ao resultado final da malha foram feitos os seguintes processos de criação:

1. Importação do fixador interno do Solid Edge ${ }^{\circledR}$ (sólido salvo com a extensão IGES) para o ANSYS $^{\circledR}$ (Fig. 23); 


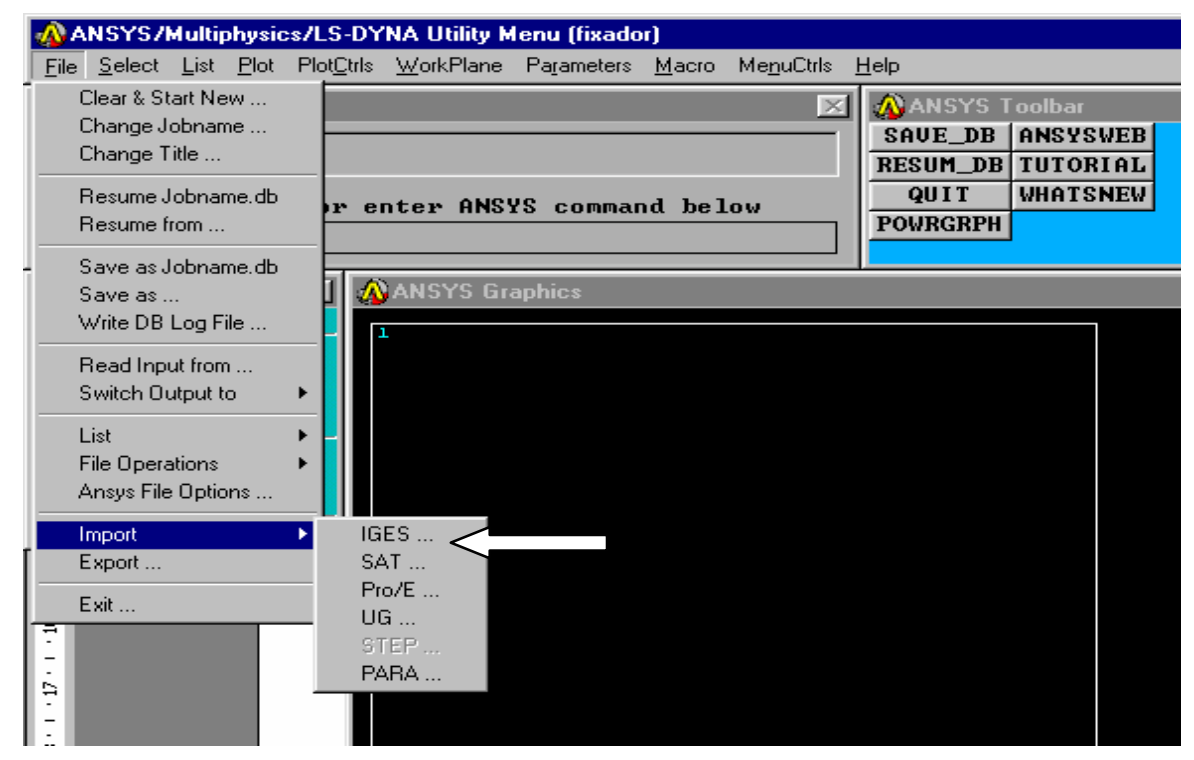

Fig. 23 - Importação do sólido no formato IGES ${ }^{\circledR}$

2. Criação do volume das peças através dos comandos "Preprocessor", "Create" e "Volume" (Fig. 24). O mesmo poderá ser feito para a criação de linhas, áreas, nós, elementos, superfície de contacto entre outros.

3. Um dos pontos principais foi a utilização do comando "SAVE DB" que salvou os arquivos e estes passaram a ter a extensão DB que é a utilizada pelo ANSYS $^{\circledR}$ (Fig. 25). Todos os arquivos são chamados "Jobname.ext", onde "ext" é a extensão do $\operatorname{ANSYS}^{\circledR}$ que define o seu conteúdo. O “Jobname" especificado ao se entrar no ANSYS ${ }^{\circledR}$ é chamado de "Jobname inicial" e pode ser mudado a qualquer momento dentro de uma sessão do software. 


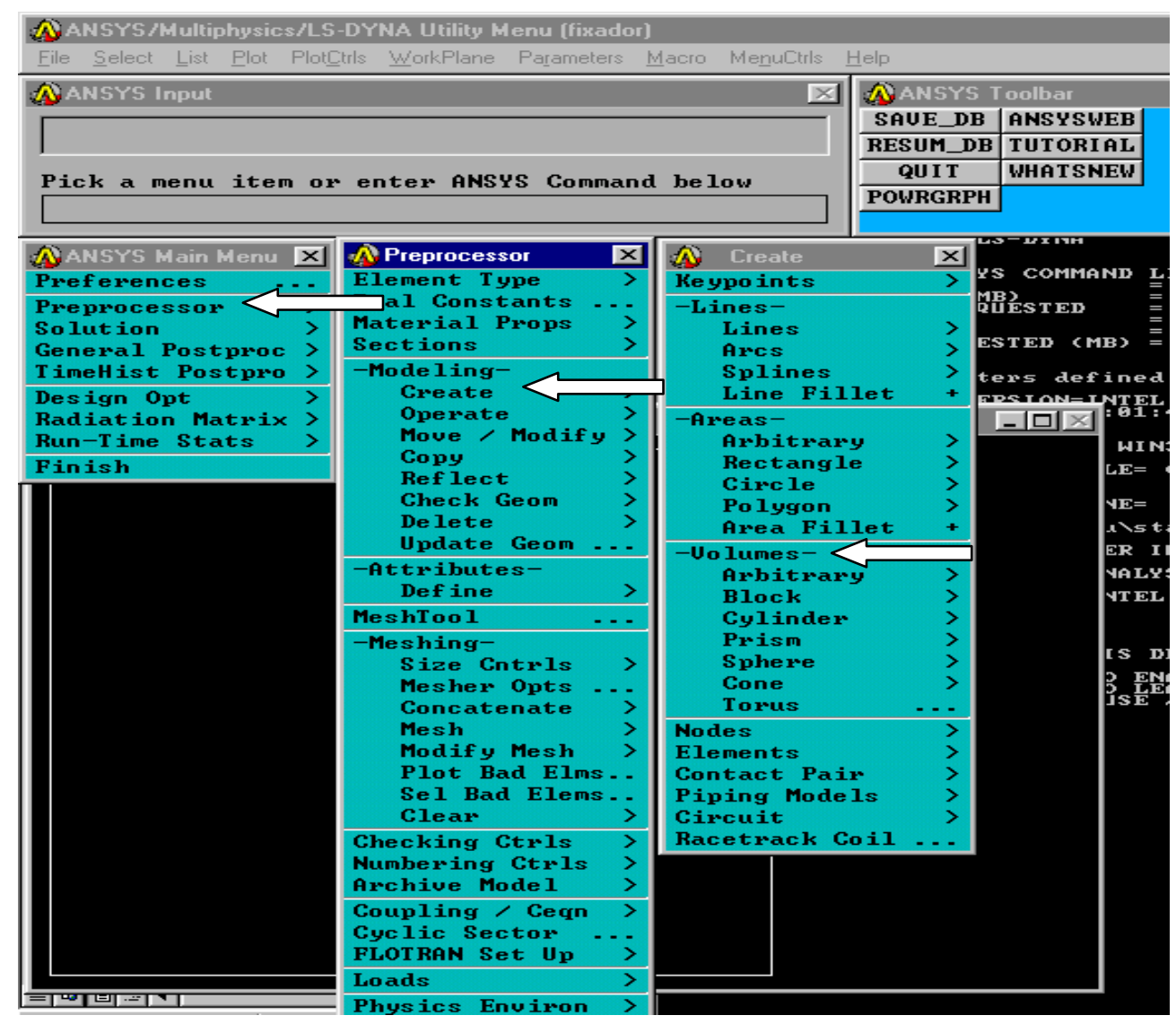

Fig. 24 - Criação do volume da peça importada.

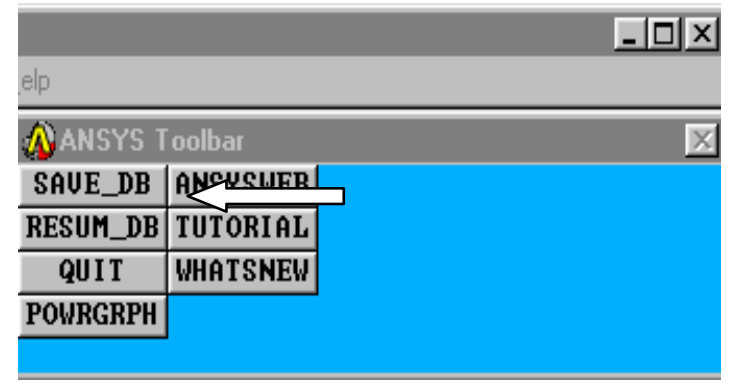

Fig. 25 - Utilização do comando de salvamento

4. Através da caixa de diálogo "Preferences" foi feita a escolha da área de interesse ("disciplines") para o contexto da análise desejada (Fig. 26). Por um filtro de escolha dos menus todas as disciplinas foram 
mostradas ("default"). A opção "structural" foi escolhida e assim feita a anulação dos menus relativos a "thermal", "electromagnetic", "fluid", etc (tipos de análises).

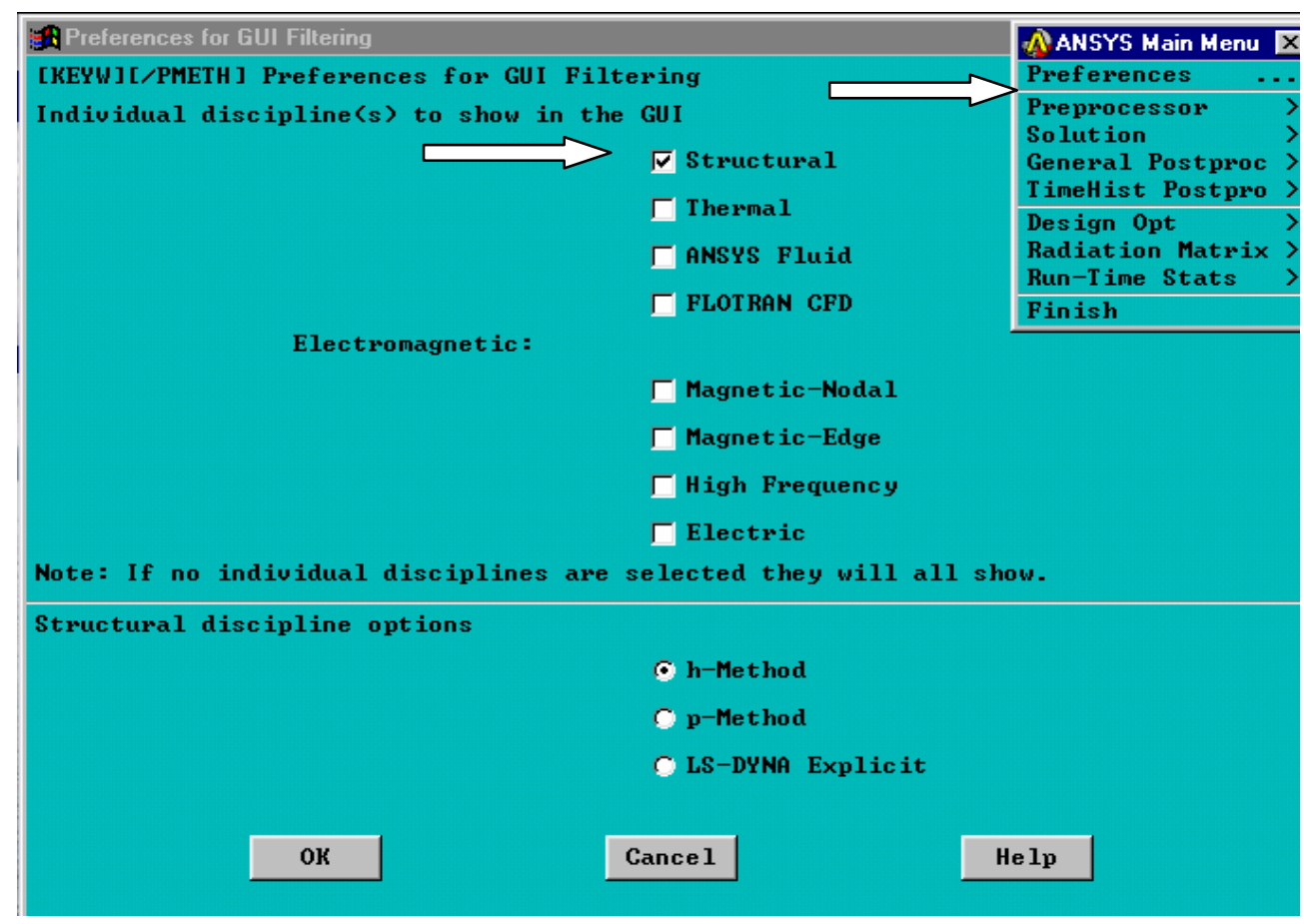

Fig. 26 - Determinação da preferência da análise

5. Em qualquer análise, é necessário partir de uma biblioteca de elementos e definir o mais apropriado. O tipo de elemento determina, entre outras coisas, o conjunto de grau de liberdade (deslocamentos, rotações, temperaturas, etc), a forma do elemento (linha, quadrilátero, tetraedro, etc), a situação do elemento no espaço bi ou tri-dimensional. Alguns elementos possuem especificações adicionais como o comportamento do elemento, simplificações, opções de impressão, etc. Assim foi feita a escolha pelo elemento tetraédrico (Fig. 27). 


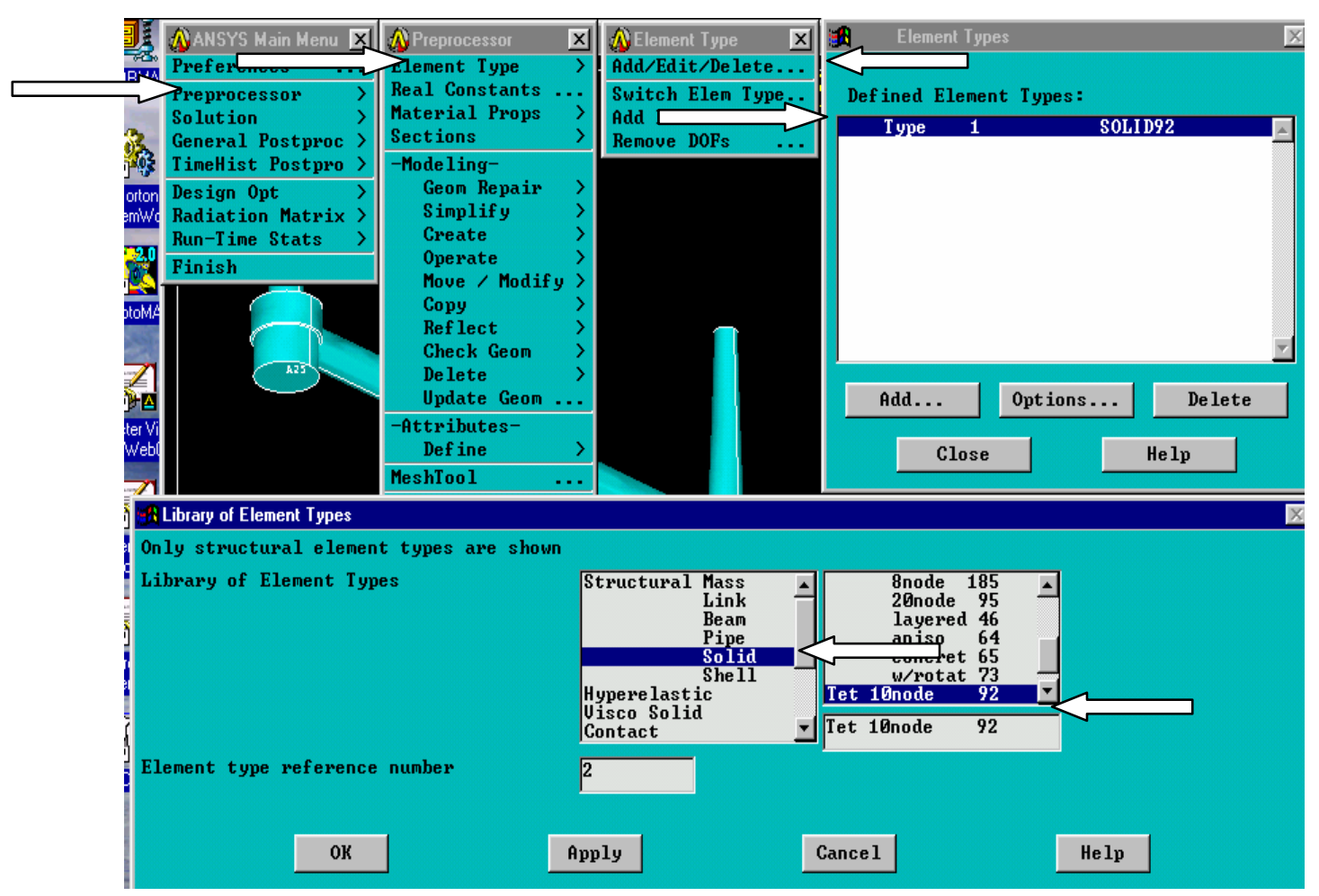

Fig. 27 - Adição do elemento tetraédrico

6. Para as análises foram necessárias as definições das propriedades dos materiais (Fig. 28). Fazem parte das propriedades constitutivas de um material o módulo de elasticidade, densidade entre outras.

As propriedades são independentes da geometria do material, embora elas não estejam amarradas ao tipo de elemento. As propriedades do material escolhido são necessárias para resolver as matrizes de cada elemento. Tem-se então aplicações de materiais lineares, não lineares e/ou anisotrópicas.

Com as constantes reais e os tipos de elementos, pode-se ter múltiplos conjuntos de propriedades de material dentro de uma análise. Sendo assim cada conjunto terá um número de referência. 
Para a análise deste trabalho o programa ANSYS ${ }^{\circledR}$ solicita os valores do módulo de Young e coeficiente de Poisson, mas não limita a análise a somente estas duas propriedades (Fig. 29).

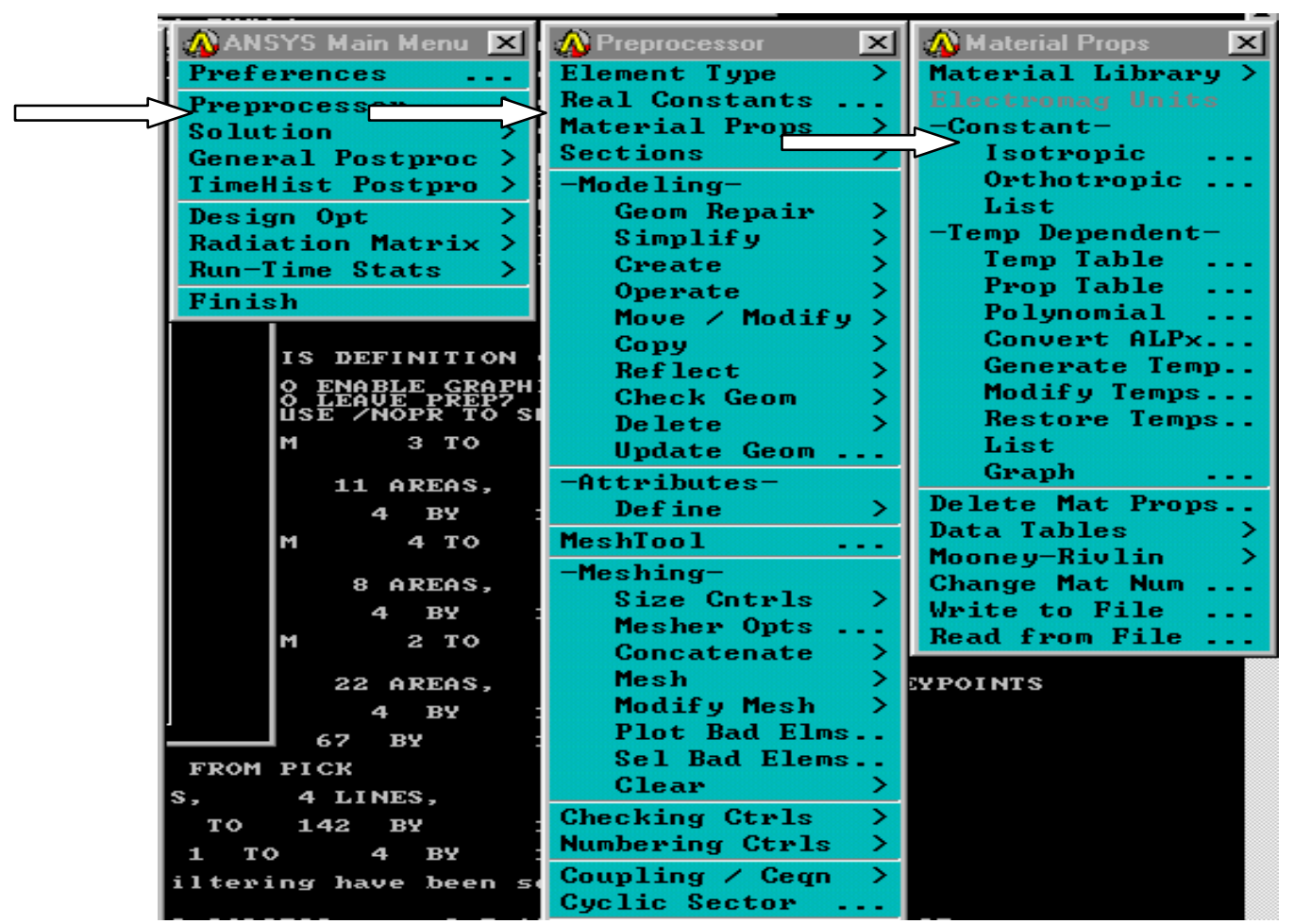

Fig. 28 - Definição das propriedades do material

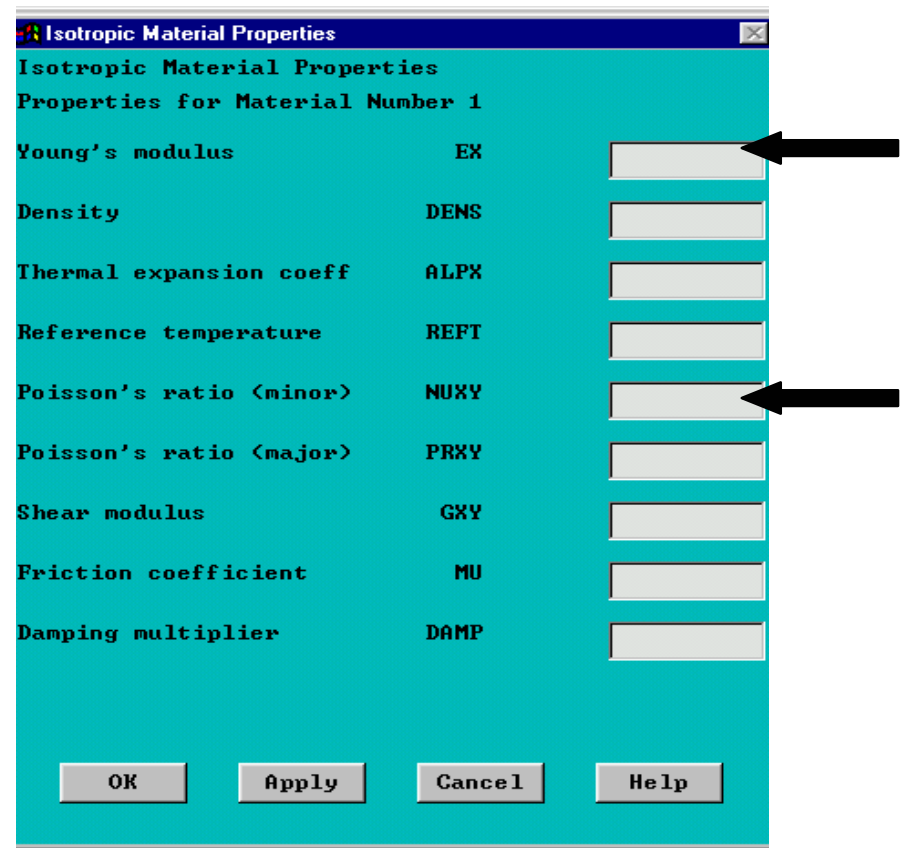

Fig. 29 - Tabela das propriedades do material 
7. É nesta fase que se classifica segundo o tamanho e o comprimento da extremidade do elemento, aumentando ou diminuindo o número de nós e elementos (Fig. $30 \mathrm{~A}, \mathrm{~B}$ ). Os tetraedros gerados no fixador interno de coluna foram feitos através da utilização dos comandos do "Main Menu" (fase que determina o número de elementos e nós gerados) que contém as funções primárias do $\mathrm{ANSYS}^{\circledR}$ (Fig. 31), organizadas por processos ("preprocessor", "solution", "general postprocessor", "design optimizer", etc). O resultado final foi o sólido formado por elementos tetraedros (Fig. 32).

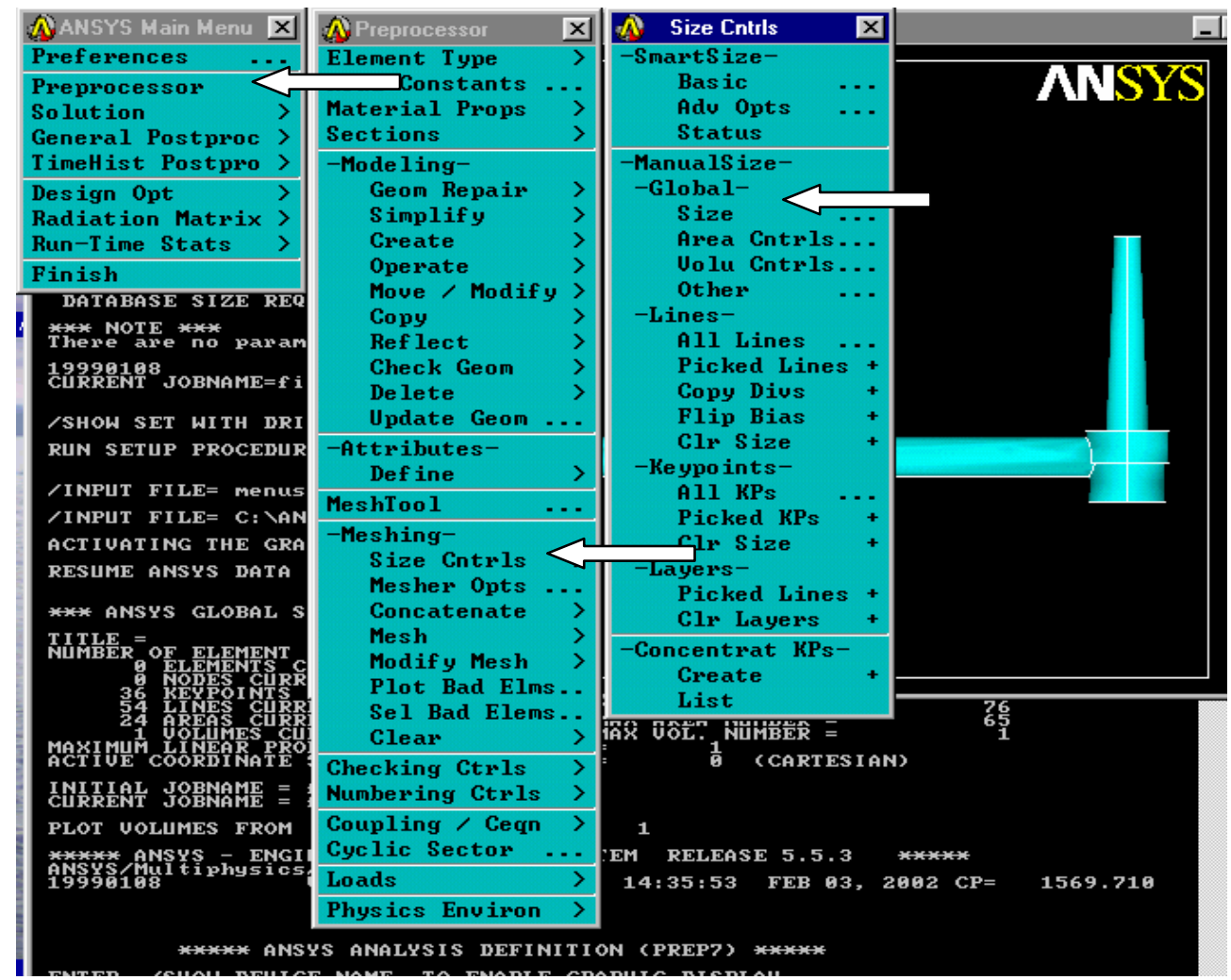

Fig. 30 - (A) Geração do tamanho do elemento 


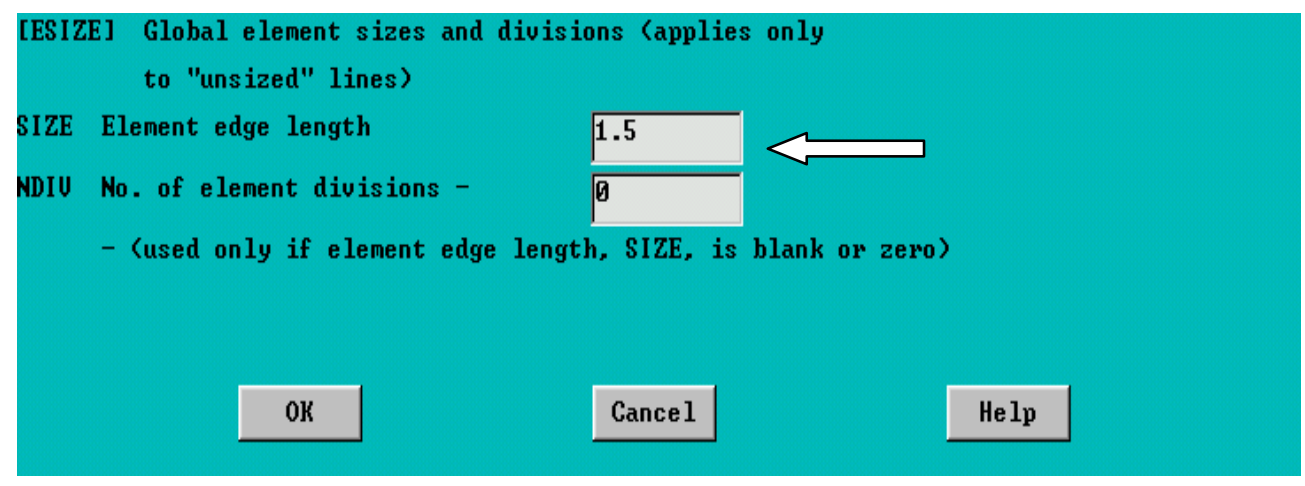

Fig. 30 - (B) Tabela de tamanho do elemento

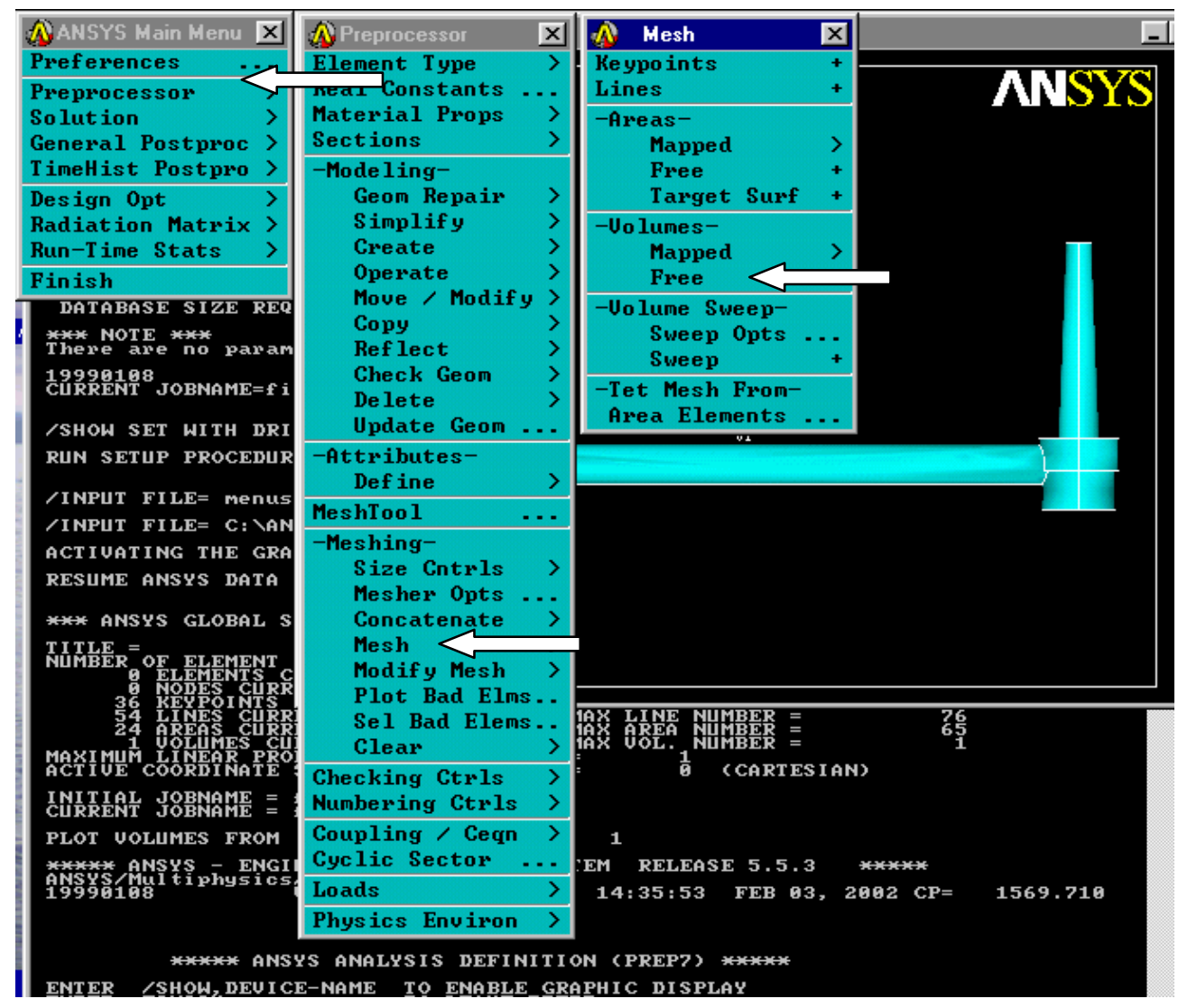

Fig. 31 - Definição da malha tetraédrica 


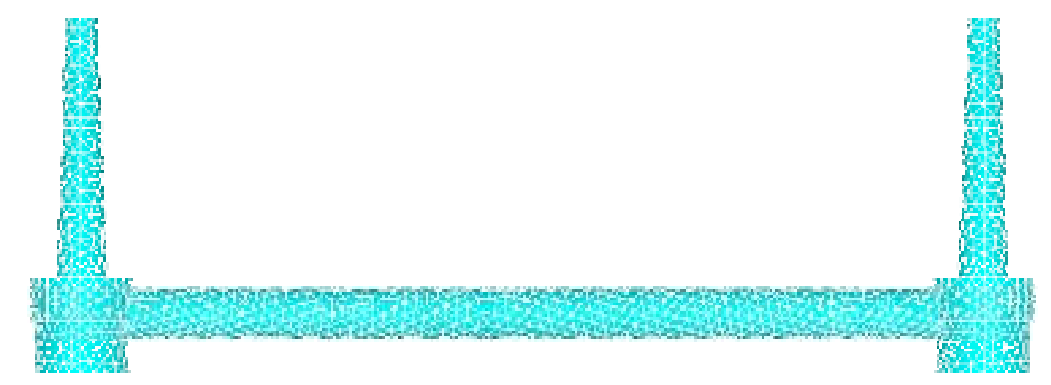

Fig. 32 - Resultado final da geração das malhas

\subsection{SIMULAÇÃO}

Gerada a malha aplicamos restrições de deslocamento (parte inferior) para determinação das tensões na superfície. As restrições tem por objetivo impor deslocamento nulo (travar) em toda parte selecionada (parte inferior) para que seja possível a aplicação das diferentes cargas na parte oposta (parte superior) (Fig. 33-A, B).

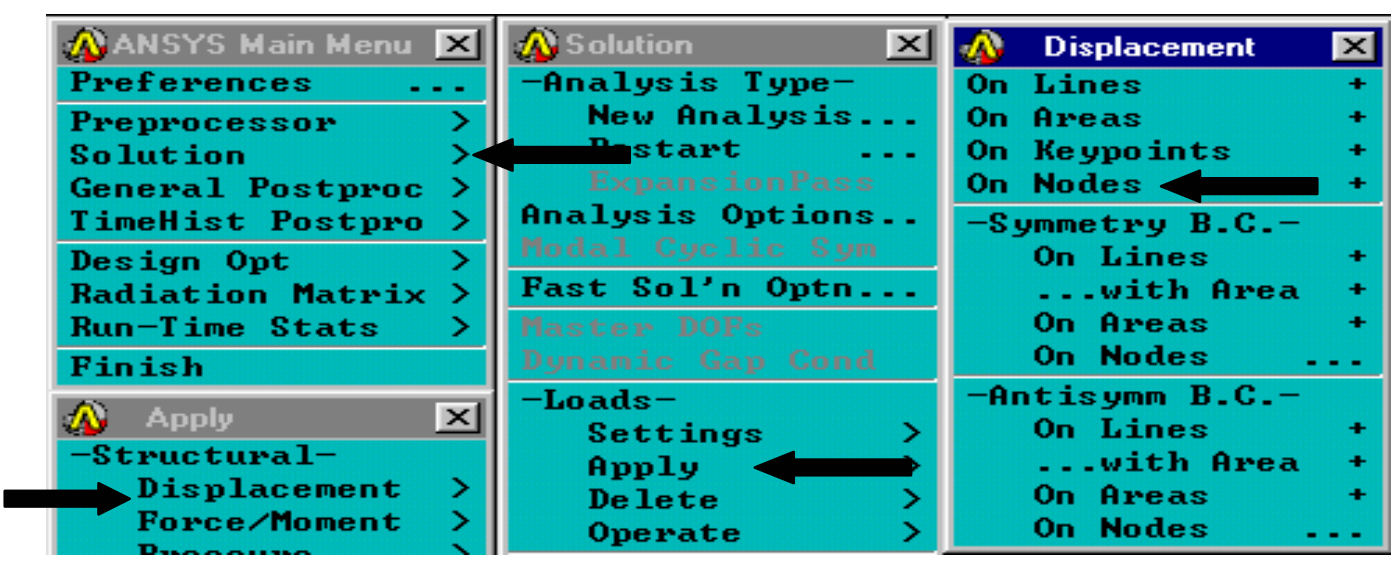

Fig. 33 - (A) Menu para aplicação de restrições 


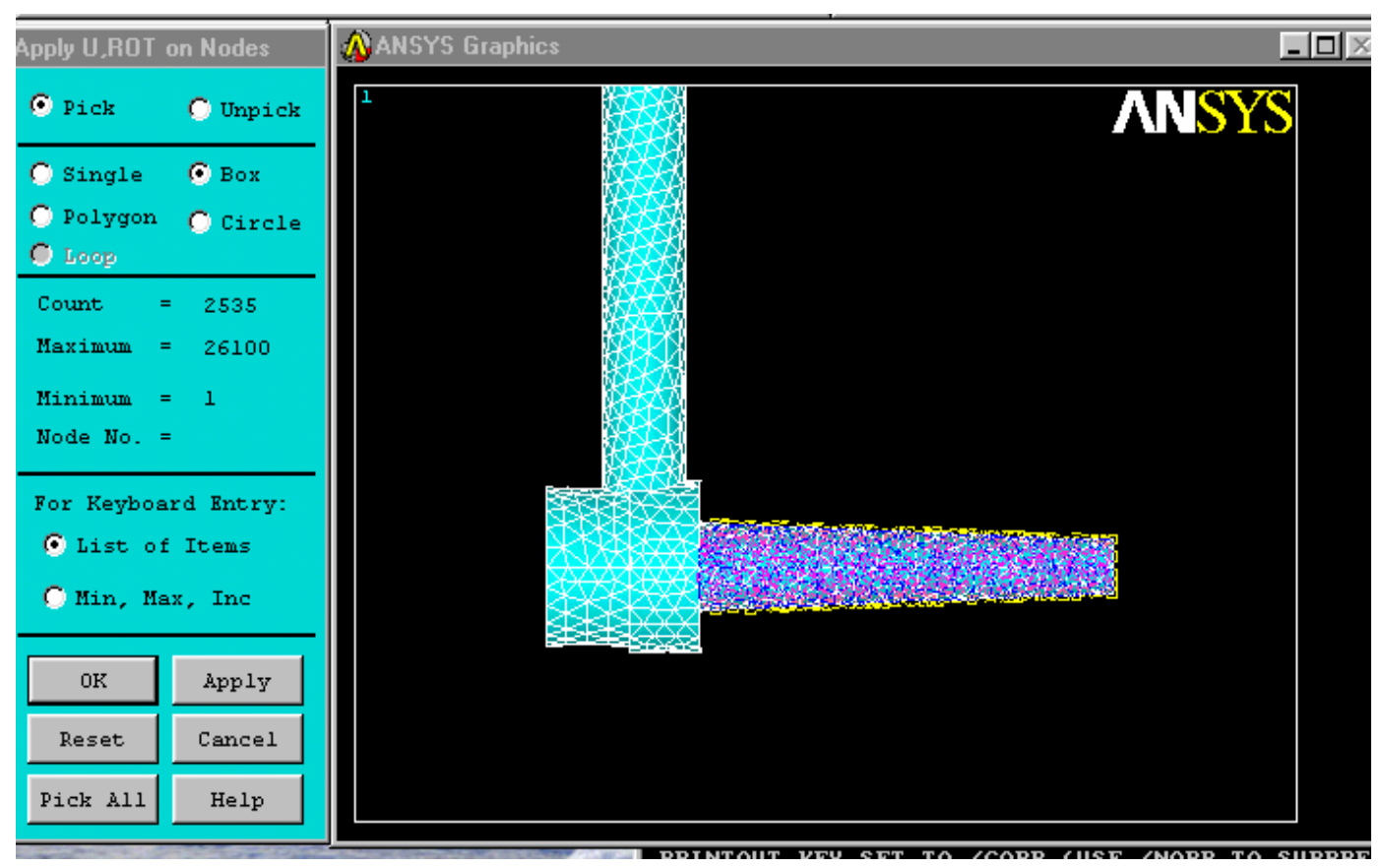

Fig. 33 - (B) Restrição da parte inferior do fixador

Feita as restrições do parafuso (parte inferior) foram aplicadas as cargas e então iniciadas as simulações utilizando o método dos elementos finitos (Fig. 34-A, B). As cargas foram aplicadas na parte superior do fixador (parafuso).

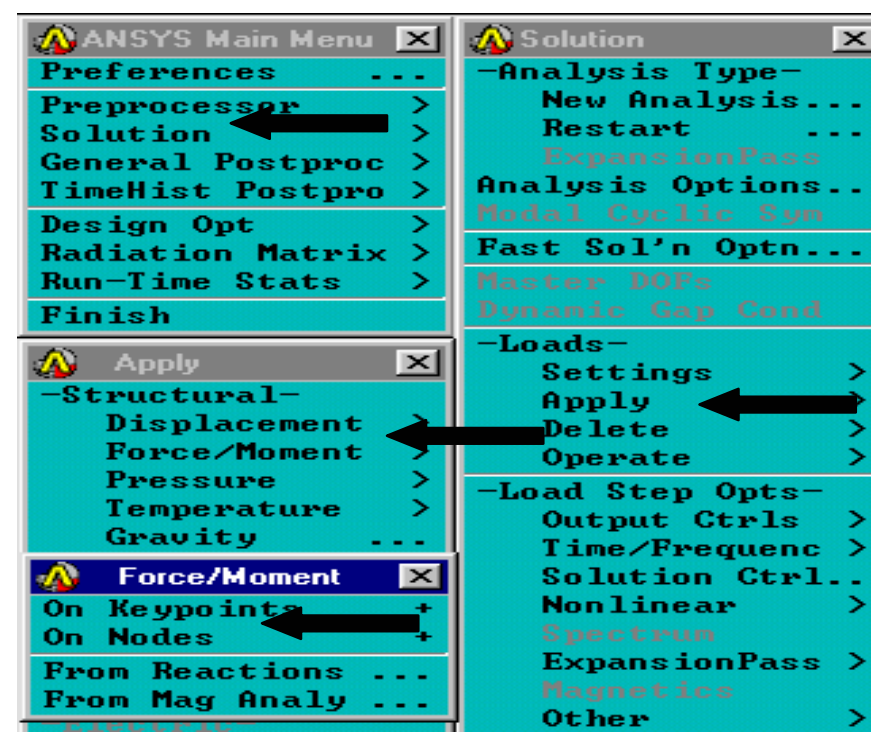

Fig. 34 - (A) Menu para aplicação das cargas 


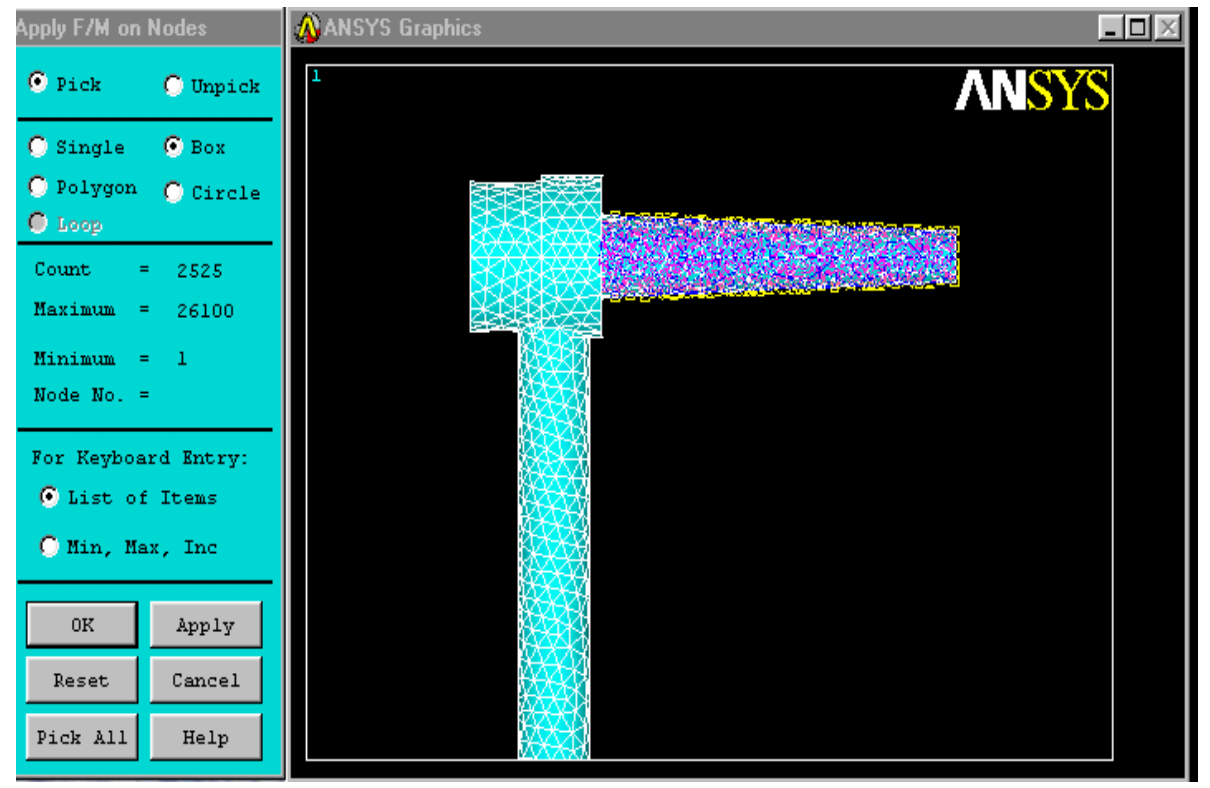

Fig. 34 - (B) Aplicação da carga na parte superior do fixador

A partir deste ponto o Ansys ${ }^{\circledR}$ começa a gerar as soluções (Fig. 35) sendo que várias opções podem ser seguidas:

- Se o solução não converge, o deslocamento imposto é grande e gera uma deformação muito grande ultrapassando a região estudada, ou muito pequena que não chega a atingir a região.

- Se a solução converge, então pode-se visualizar os resultados e verificar os níveis de tensão para o deslocamento imposto e, se estes forem pequenos, significa que o deslocamento imposto foi suficiente para levar a uma região de solução. Se as tensões estão altas, deve-se diminuir o deslocamento até gerar tensões baixas no contato, calibrando o valor do deslocamento colocado.

- Se os dois problemas anteriores forem solucionados, deve-se rodar novamente a solução com o novo deslocamento, sem sair do módulo "Solution" deletando o deslocamento colocado e aplicando a 
força ou seja realizar um novo ensaios sem a necessidade da construção de um novo corpo de prova.

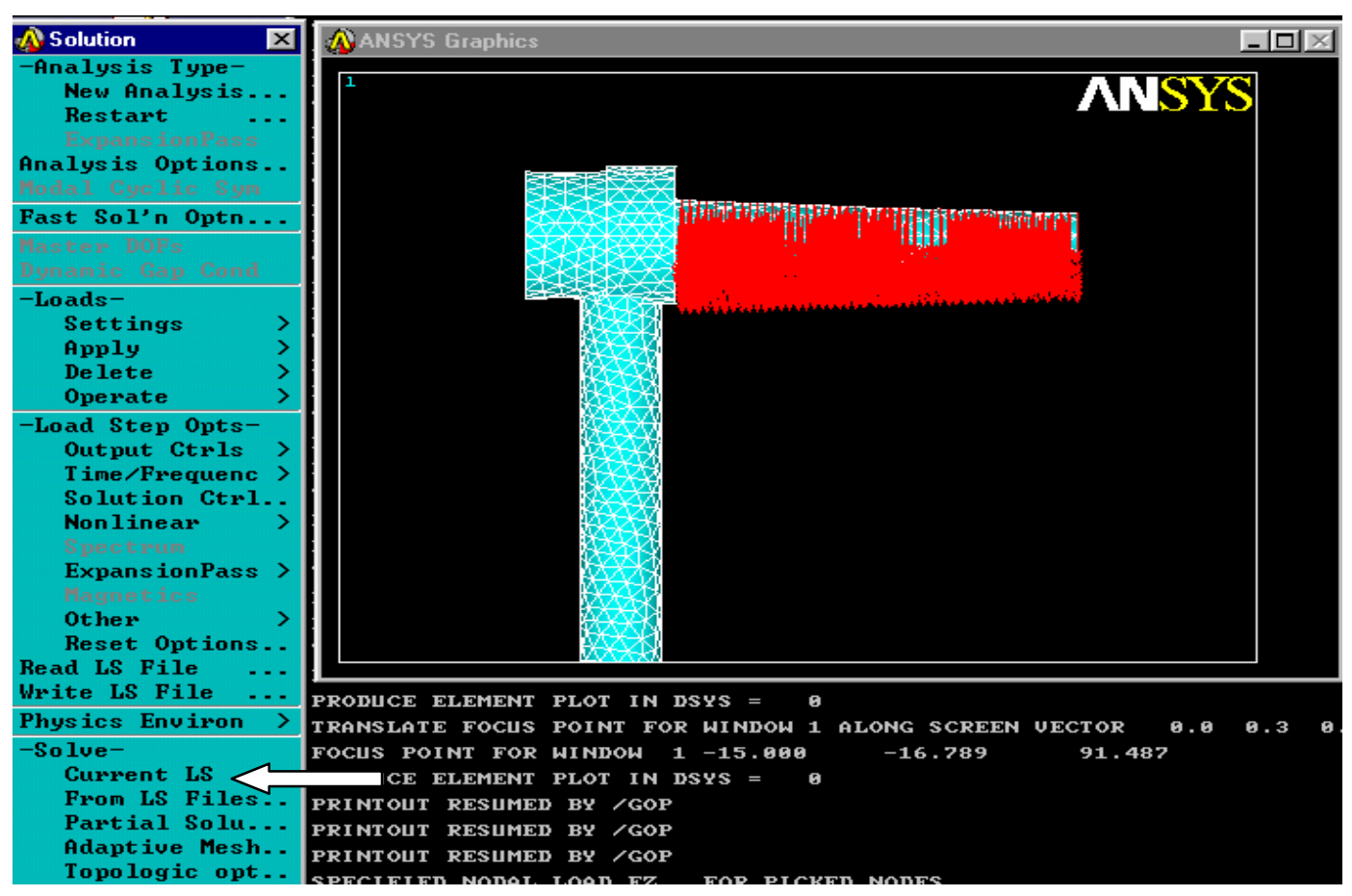

Fig. 35- Geração da solução 


\section{RESULTADOS}

Através do software de simulação $\left(\right.$ ANSYS $\left.^{\circledR}\right)$ foram aplicadas as diferentes cargas nos ensaios de flexo-compressão e flexão lateral.

A TABELA 2 mostra os diferentes valores das cargas aplicadas nos fixadores internos de coluna (titânio e alumínio). Os valores das forças foram colocados em ordem decrescente para a observação das possíveis deformações ocorridas na peça.

Tabela 2 - Valores para ensaios de carregamento (força)

\begin{tabular}{cc}
\hline ENSAIO & CARGA(KN) \\
\hline 1 & 0,0365 \\
3 & 0,0280 \\
4 & 0,0176 \\
5 & 0,0153 \\
6 & 0,0122 \\
7 & 0,0080 \\
\hline
\end{tabular}

\subsection{ENSAIOS REALIZADOS NO FIXADOR DE TITÂNIO (liga)}

Realizada a modelagem do fixador no software Solid Edge ${ }^{\odot}, 0$ modelo foi exportado para o Software ANSYS $^{\circledR}$ e gerado o volume. O 
elemento utilizado na malha foi determinado após uma análise para que

o fixador fique o mais próximo do real possível. Assim o elemento escolhido foi o sólido estrutural tetraedro 92 3D de 10 nós (elemento contido no menu de opções do software ANSYS ${ }^{\circledR}$ ).

$\mathrm{Na}$ primeira simulação foram utilizadas as propriedades do material titânio (liga) e as cargas mostradas na tabela 2 (Fig. 36).

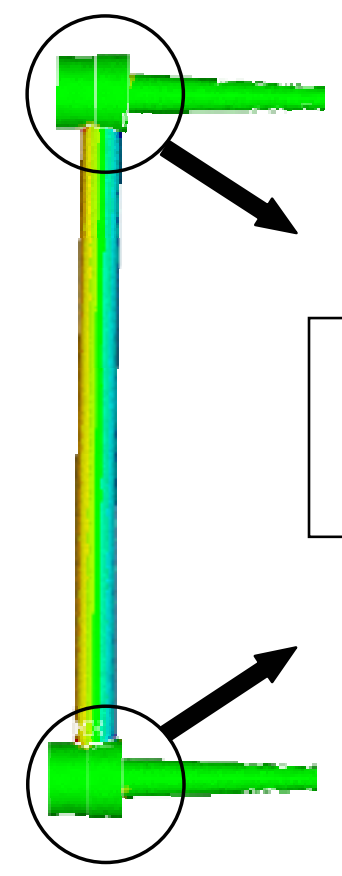

Tabela de cores mostrando a intensidade das tensões (valores em MPa)

Fig. 36 - Aplicação de uma carga de $0,0365 \mathrm{KN}$ em um ensaio de flexocompressão no fixador de titânio (liga)

O degrade de cores apresentado pelo programa ANSYS nas diversas simulações possui valores com sinais negativos e positivos. Estes sinais vem a ser o esforço que provoca simultaneamente tensões de compressão e tração numa peça e é chamada de flexão. Estas duas tensões são chamadas de tensões externas, e são fundamentais ao estudo, sendo a tensão máxima (tração) e a tensão mínima (compressão). 
O programa ANSYS também apresenta durante a simulação o ponto de maior e menor tensão apresentados na peça pelas letras MN (menor) e MX (maior).

Nos primeiros ensaios realizados foi observado que durante a simulação o corpo de prova se deformava de uma forma destrutiva, pois ao importar-se a peça para ANSYS ${ }^{\circledR}$ esta só possuía superfície. O Solid Edge $^{\circledR}$ se mostrou eficiente e de fácil manipulação na construção do sólido, mas apresentou esta deficiência durante a exportação. O problema foi solucionado no software ANSYS ${ }^{\circledR}$, mesmo que o sólido (fixador) não tenha sido construído no mesmo. O software possui em seu menu a opção para a construção de áreas, volumes, linhas e nós.

Foram realizados sete ensaios de flexo-compressão e flexão lateral, aplicando as cargas da tabela 2. Os ensaios foram feitos pela aplicação de forças progressivas, até que ocorresse a falência estrutural. A figura 38 apresenta a imagem do modelo e seu deslocamento.

A escolha dos metais foi determinada após um estudo onde se verificou que o alumínio (liga) foi utilizado por um grande período tempo na fixação de coluna. Este metal foi substituído pelo titânio (liga) depois de alguns estudos identificarem que o mesmo deixava vestígios de metal na corrente sangüínea. Já o titânio não apresentava implicações tóxicas, não se aderia a micro organismos por causa da camada terrestre e é o nono elemento em ordem de abundância e o terceiro metal utilizado para construções mecânicas depois do alumínio e do ferro. Suas propriedades proporcionam várias vantagens: biocompatibilidade, baixo peso específico, baixa dureza e facilidade de acabamento, mínima 
condutibilidade térmica, absoluta ausência de sabores, elevada rádiotranslucidez.

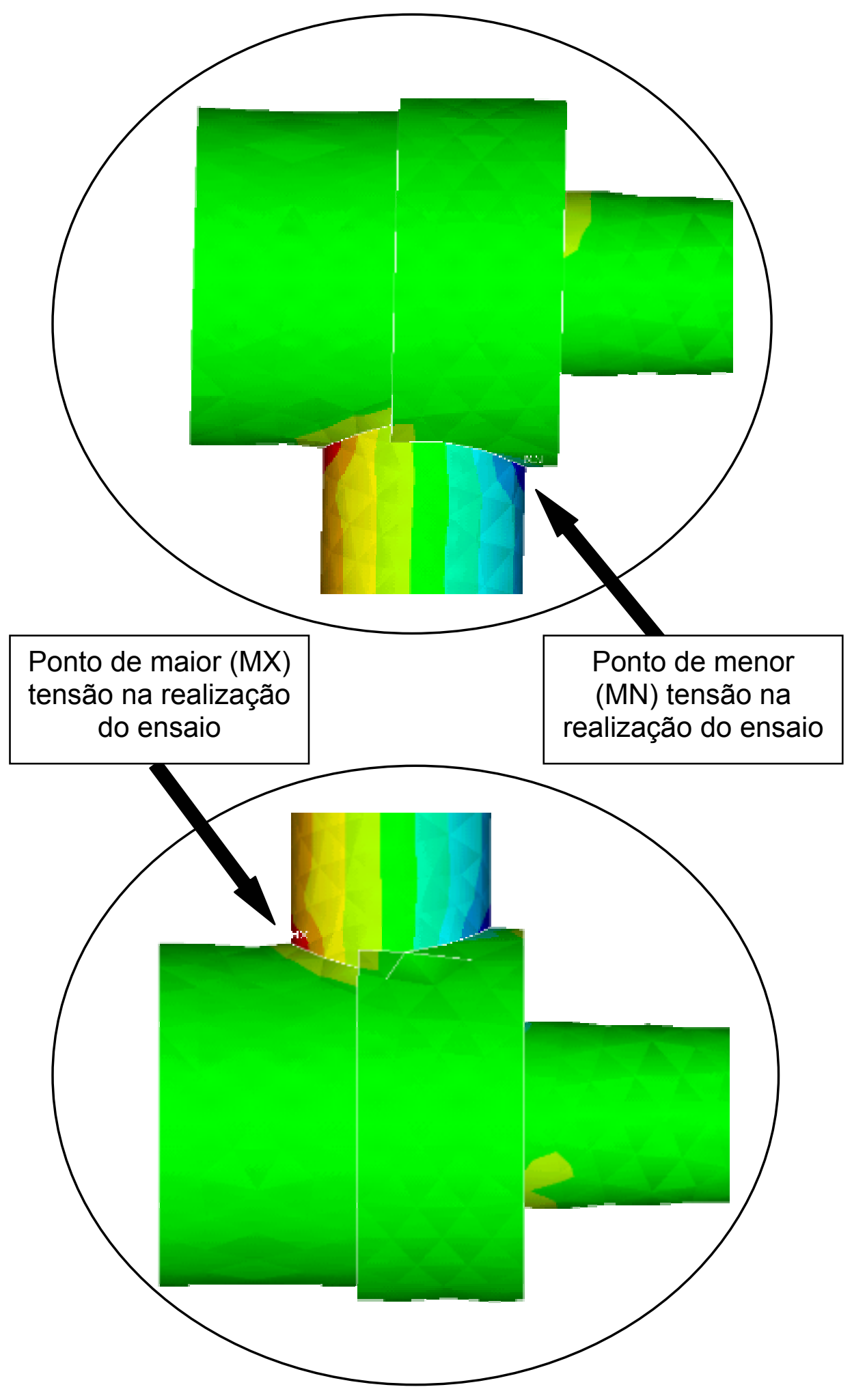

37 - (A), (B) Ponto de maior e menor tensão no fixador de titânio (liga) durante o ensaio de flexo-compressão 


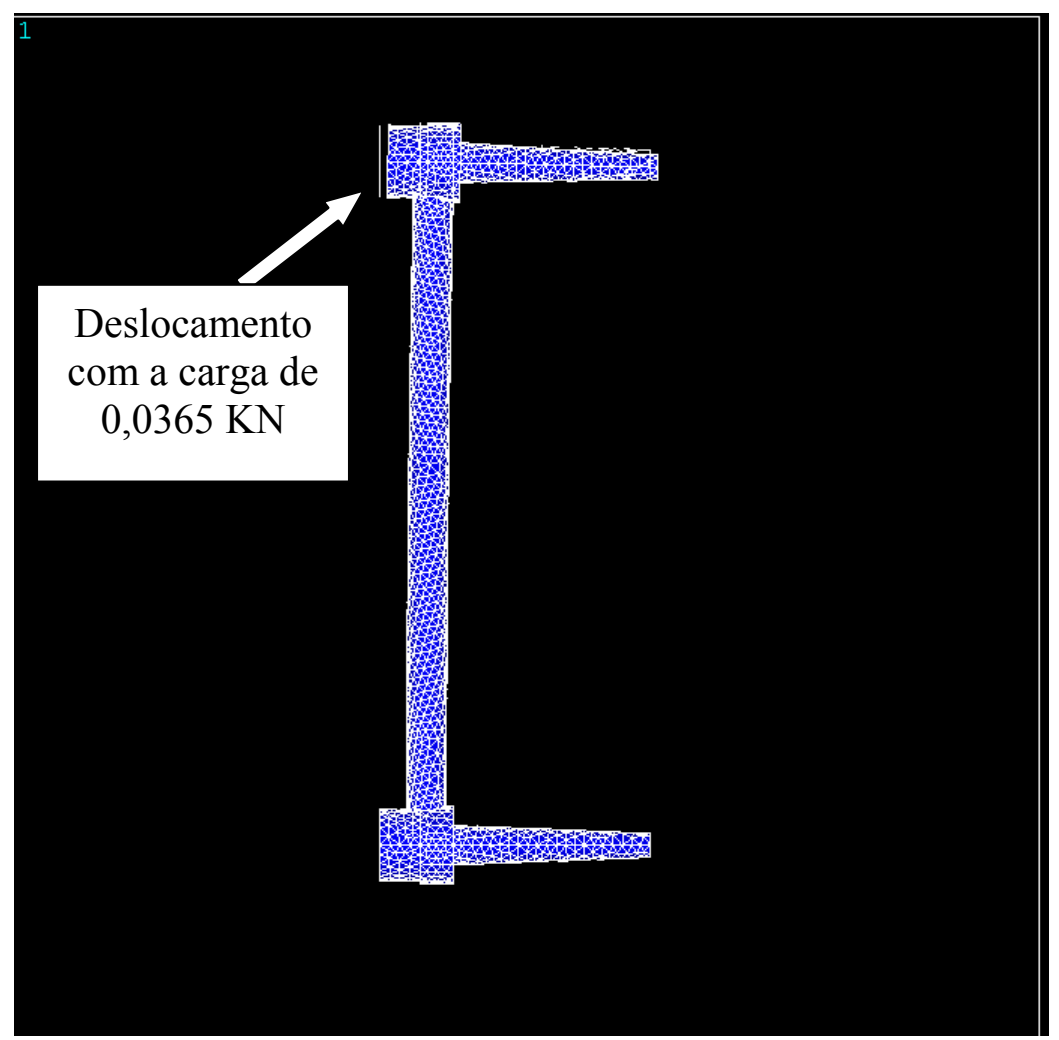

Fig. 38 - Deformação sofrida pelo fixador de titânio (liga) no ensaio de flexo-compressão com carga de 0,0365 KN

Tabela 3 - Resultados gerais realizados nos ensaios de flexocompressão (liga de titânio)

\begin{tabular}{|c|c|c|c|c|c|c|c|c|c|c|}
\cline { 2 - 11 } \multicolumn{1}{c|}{} & \multicolumn{9}{c|}{ Resultados das variações das tensões (MPa) } \\
\hline Ensaios & & & & & & & & & & \\
\hline 1 & -124.647 & -98.768 & -72.888 & -47.009 & -21.13 & 4.749 & 30.628 & 56.507 & 82.386 & 108.266 \\
\hline 2 & -95.929 & -76.025 & -56.12 & -36.216 & -16.311 & 3.593 & 23.497 & 43.402 & 63.306 & 83.211 \\
\hline 3 & -59.959 & -47.508 & -35.057 & -22.606 & -10.156 & 2.295 & 14.746 & 27.197 & 39.648 & 52.099 \\
\hline 4 & -52.425 & -41.548 & -30.67 & -19.793 & -8.916 & 1.962 & 12.839 & 23.717 & 34.594 & 45.471 \\
\hline 5 & -41.589 & -32.955 & -24.321 & -15.687 & -7.053 & 1.581 & 10.215 & 18.849 & 27.483 & 36.117 \\
\hline 6 & -27.415 & -21.727 & -16.039 & -10.251 & -4.662 & 1.026 & 6.714 & 12.402 & 18.09 & 23.779 \\
\hline 7 & -22.169 & -17.567 & -12.964 & -8.362 & -3.759 & 0.843238 & 5.446 & 10.048 & 14.651 & 19.253 \\
\hline
\end{tabular}




\section{LEGENDA}

Variações crescentes das tensões

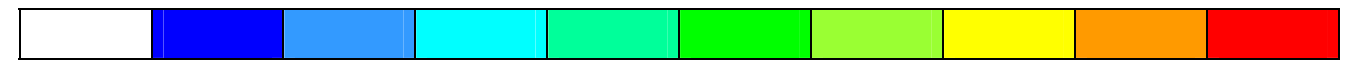

Variações das tensões em MPa.

\begin{tabular}{|c|c|c|c|c|c|c|}
\hline \multicolumn{7}{|c|}{ ENSAIOS REALIZADOS EM KN } \\
\hline $\mathbf{1}$ & $\mathbf{2}$ & $\mathbf{3}$ & $\mathbf{4}$ & $\mathbf{5}$ & $\mathbf{6}$ & $\mathbf{7}$ \\
\hline 0,0365 & 0,0280 & 0,0176 & 0,0153 & 0,0122 & 0,0080 & 0,0065 \\
\hline
\end{tabular}

Realizados os ensaios de flexo-compressão, foi efetuado o segundo passo que foram os ensaios de flexão lateral com os mesmos valores de cargas da tabela 2, mas foi observado que o fixador de alumínio (liga) sofreu uma deformação maior (Fig. 39).
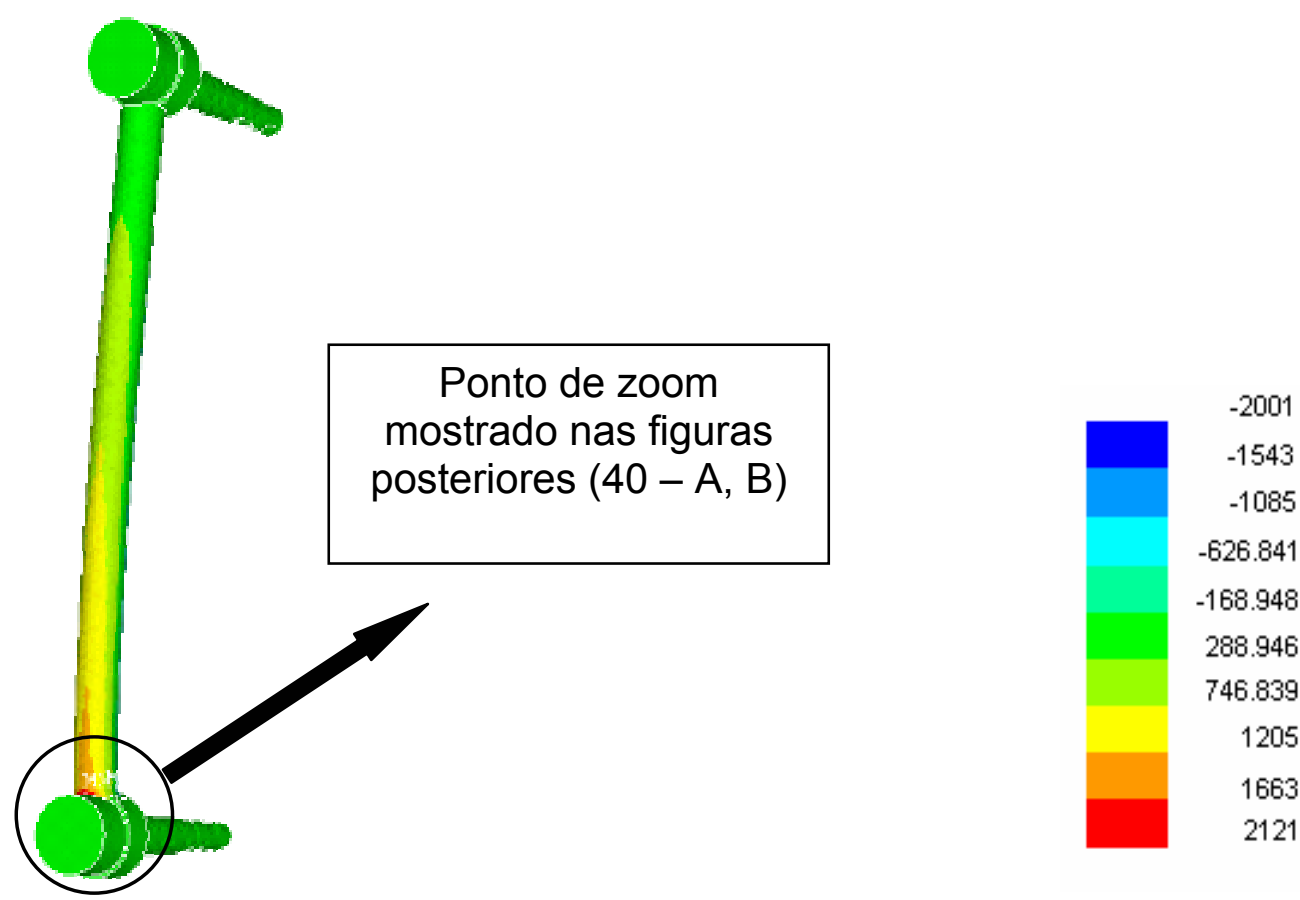

Fig. 39 - Aplicação de uma carga de 0,0365 $\mathrm{N}$ em um ensaio de flexão lateral no fixador de alumínio (liga)

Neste ensaio de flexão lateral, o fixador interno de coluna concentrou a maior tensão na base inferior e uma deformação grande na 
parte superior. Lembrando que neste ensaio a parte inferior do fixador é totalmente fixa.

Tabela 4 - Resultados gerais realizados nos ensaios de flexão lateral (liga de titânio)

\begin{tabular}{|c|c|c|c|c|c|c|c|c|c|c|}
\cline { 2 - 11 } \multicolumn{1}{c|}{} & \multicolumn{8}{c|}{ Resultados das variações das tensões (MPa) } \\
\hline Ensaios & & & & & & & & & & \\
\hline 1 & -2001 & -1543 & -1085 & -626.841 & -168.948 & 288.946 & 746.839 & 1205 & 1663 & 2121 \\
\hline $\mathbf{2}$ & -1535 & -1183 & -832.115 & -480.896 & -129.677 & 221.542 & 572.762 & 923.981 & 1275 & 1626 \\
\hline $\mathbf{3}$ & -957.442 & -738.283 & -519.124 & -299.965 & -80.806 & 138.353 & 357.512 & 576.671 & 795.83 & 1015 \\
\hline $\mathbf{4}$ & -833.476 & -642.693 & -451.91 & -261.127 & -70.344 & 120.439 & 311.223 & 502.006 & 692.789 & 883.572 \\
\hline $\mathbf{5}$ & -669.361 & -513.078 & -360.794 & -208.51 & -56.227 & 96.057 & 248.34 & 400.624 & 552.908 & 705.191 \\
\hline $\mathbf{6}$ & -438.457 & -338.097 & -237.738 & -137.738 & -37.018 & 63.341 & 163.701 & 264.061 & 364.421 & 464.78 \\
\hline $\mathbf{7}$ & -353.558 & -272.638 & -191.718 & -110.798 & -29.878 & 51.042 & 131.962 & 212.882 & 293.802 & 374.722 \\
\hline
\end{tabular}

A figura 41, mostra a deformação sofrida pelo fixador interno de coluna durante o ensaio de maior carga.

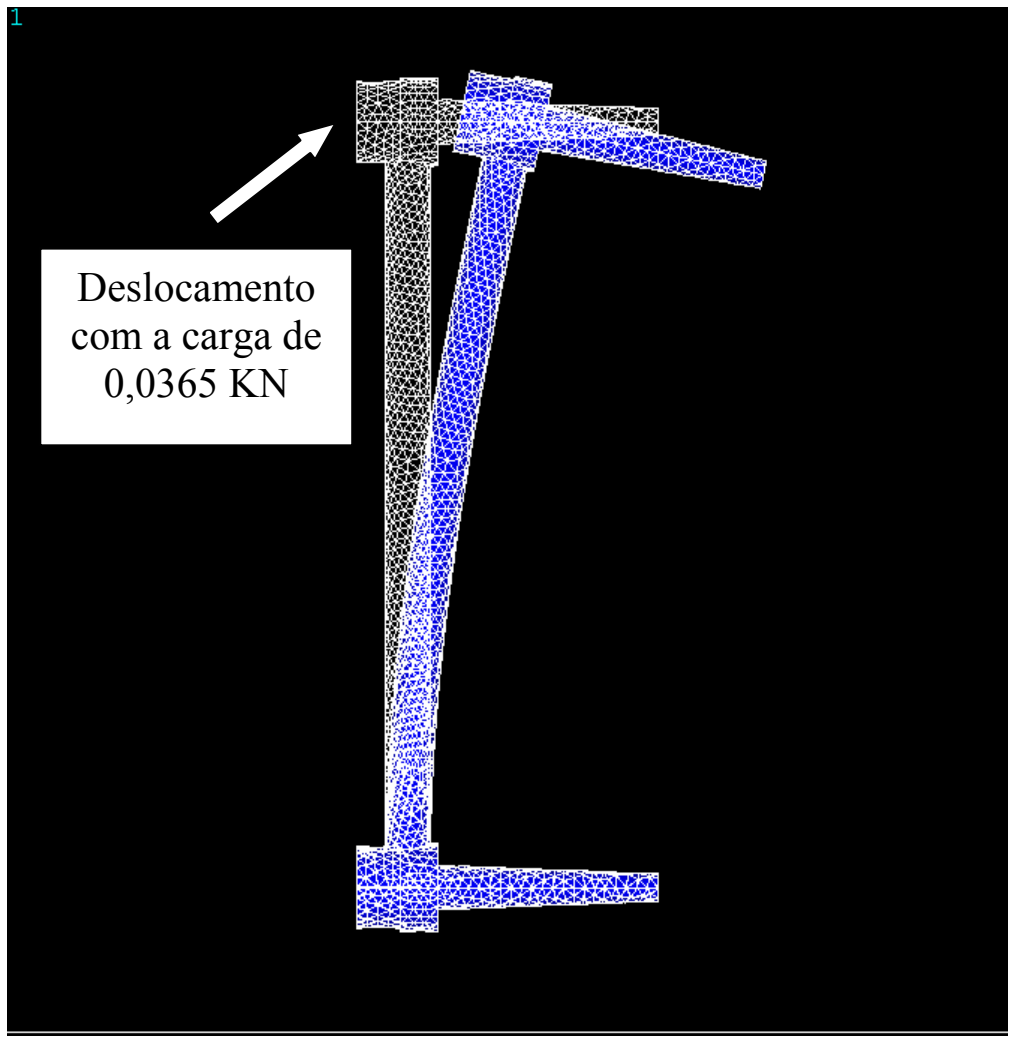

Fig. 41 - Deformação sofrida pelo fixador de titânio no ensaio de flexão lateral com carga de 0,0365 KN 


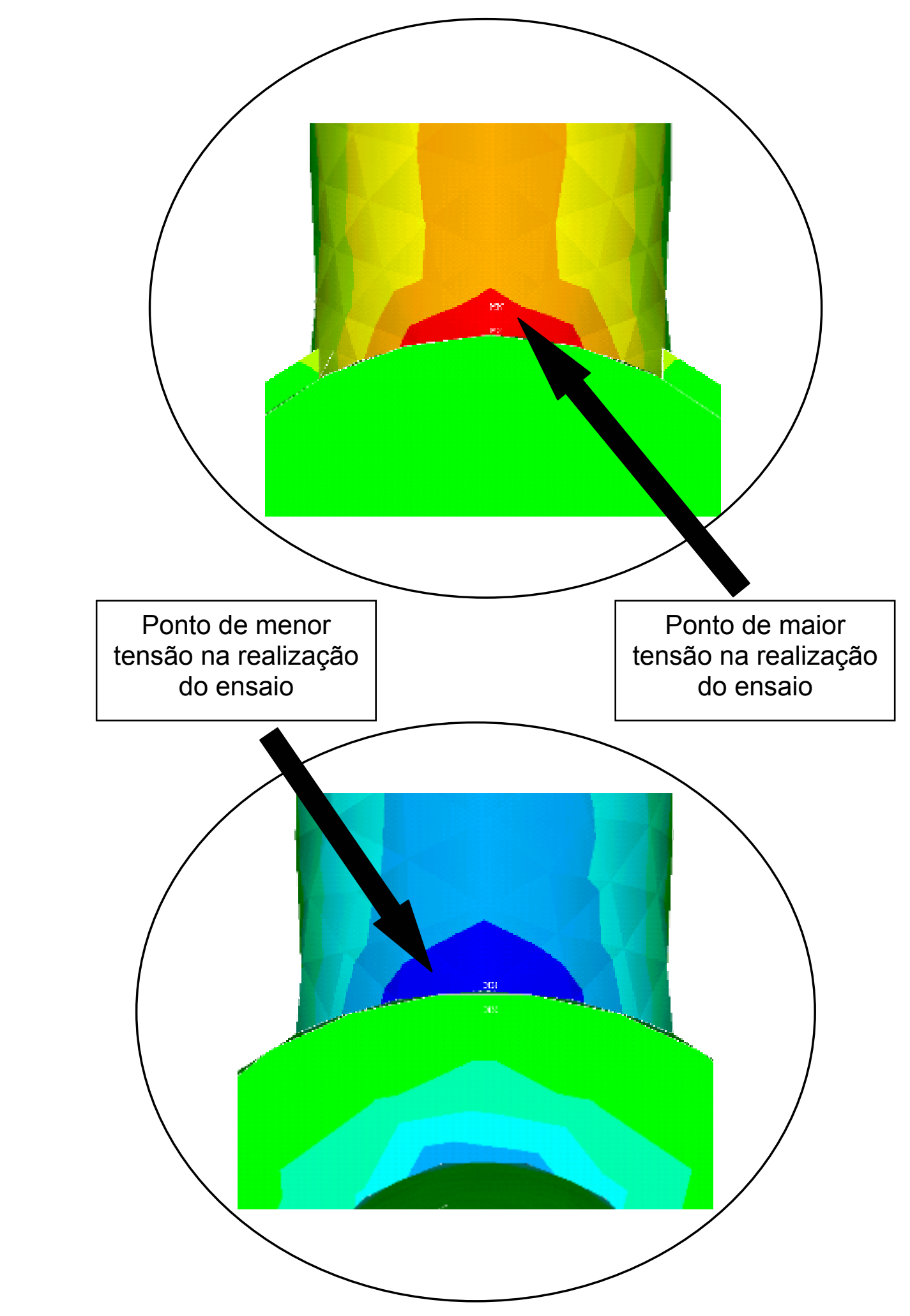

40 - (A),(B) Ponto de maior e menor tensão no fixador de alumínio (liga) durante o ensaio de flexão lateral 


\subsection{ENSAIOS REALIZADOS NO FIXADOR DE ALUMÍNIO}

O material utilizado para estas simulações foi a liga de alumínio, mas o elemento utilizado continuou sendo o sólido estrutural tetraedro 92 3D de 10 nós. Assim foram iniciadas as simulações de flexocompressão utilizando as cargas da tabela 2 (Fig. 42).

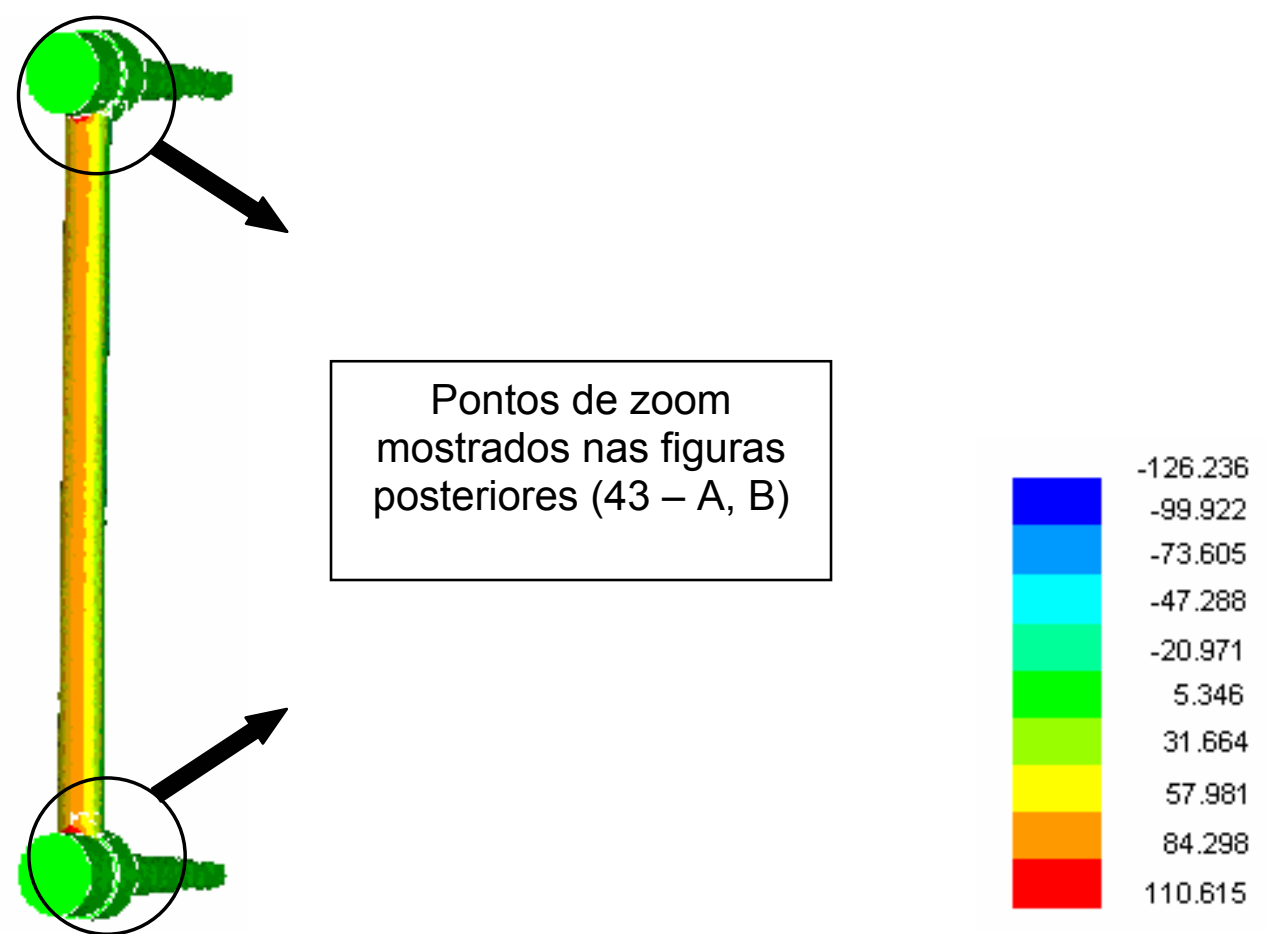

Fig. 42 - Aplicação de uma carga de 0,0365 KN em um ensaio de flexocompressão no fixador de alumínio (liga)

Pelos ensaios de flexo-compressão no fixador de alumínio (liga) os pontos de maior e menor tensão são maiores que no fixador interno composto de titânio (liga), mas com pouca diferença e mantendo os pontos críticos na junção da haste com o parafuso como mostra a figura $43-A, B$. 
Tabela 5 - Resultados gerais realizados nos ensaios de Flexocompressão (liga de alumínio)

\begin{tabular}{|c|c|c|c|c|c|c|c|c|c|c|}
\cline { 2 - 11 } \multicolumn{1}{c|}{} & \multicolumn{8}{c|}{ Resultados das variações das tensões (MPa) } \\
\hline Ensaios & & & & & & & & & \\
\hline 1 & -126.239 & -99.922 & -73.605 & -47.288 & -20.971 & 5.346 & 31.664 & 57.981 & 84.296 & 110.615 \\
\hline 2 & -96.829 & -76.643 & -56.457 & -36.27 & -16.084 & 4.102 & 24.289 & 44.475 & 64.661 & 84.848 \\
\hline 3 & -60.894 & -48.2 & -35.506 & -22.812 & -10.118 & 2.576 & 15.269 & 27.963 & 40.657 & 53.351 \\
\hline 4 & -53.019 & -41.969 & -30.918 & -19.868 & -8.818 & 2.232 & 13.283 & 24.333 & 35.383 & 46.434 \\
\hline 5 & -42.277 & -33.465 & -24.654 & -15.843 & -7.032 & 1.779 & 10.59 & 19.401 & 28.212 & 37.024 \\
\hline $\mathbf{6}$ & -27.559 & -21.812 & -16.064 & -10.316 & -4.569 & 1.179 & 6.926 & 12.674 & 18.422 & 24.169 \\
\hline 7 & -22.489 & -17.801 & -13.113 & -8.425 & -3.737 & 0.951642 & 5.64 & 10.328 & 15.016 & 19.704 \\
\hline
\end{tabular}

A deformação ocorrida no fixador interno de coluna é mostrado

na figura 44.

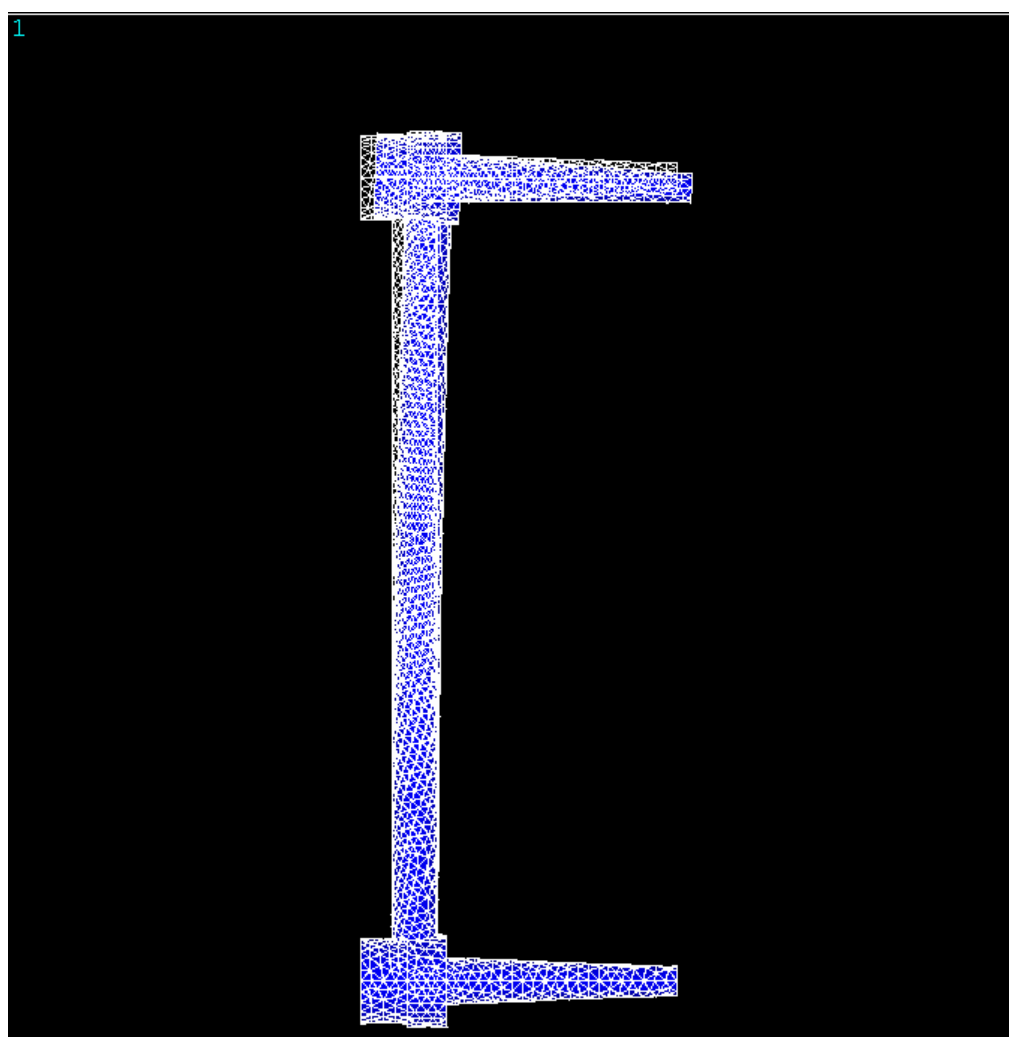

Fig. 44 - Deformação sofrida pelo fixador de alumínio (liga) no ensaio flexo-compressão com carga de 0,0365 KN 


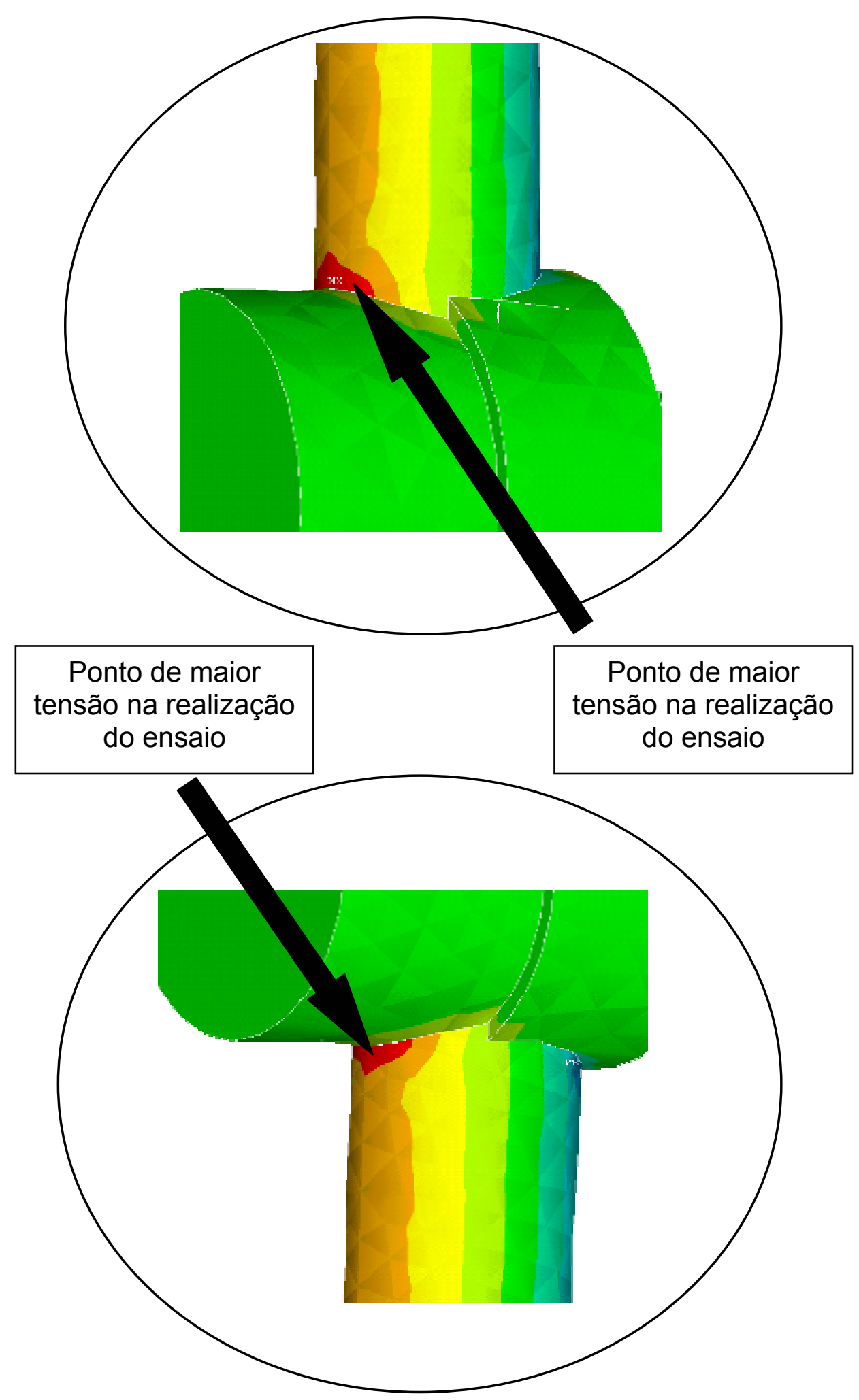

43 - (A), (B) Ponto de maiores tensões no fixador de alumínio (liga) durante o ensaio de flexo-compressão 
Após a realização dos ensaios de flexo-compressão e obtenção dos resultados, foram realizados os ensaios de flexão lateral e em seguida a observação para uma comparação entre os fixadores de titânio e o de alumínio (Fig. 45).

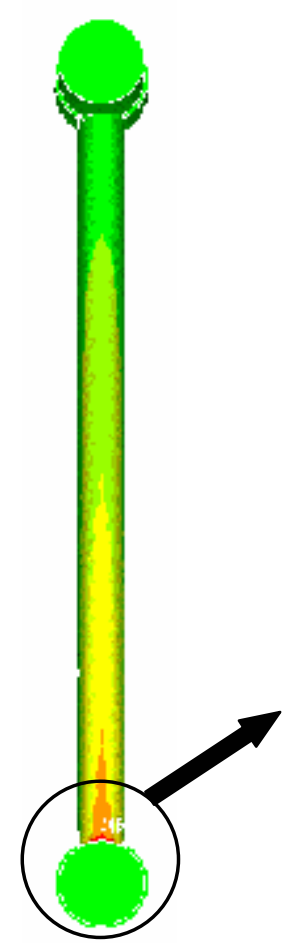

Ponto de zoom mostrado nas figuras posteriores $(46-\mathrm{A}, \mathrm{B})$

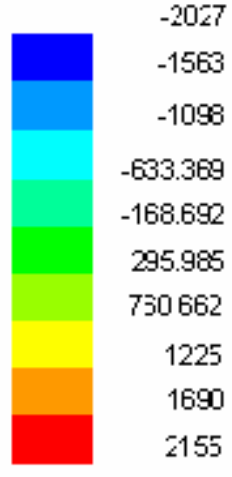

Fig. 45 - Aplicação de uma carga de 0,0365 KN em um ensaio de flexão lateral no fixador de alumínio (liga)

No ensaio de flexão lateral com uma carga máxima de 0,0365 KN, foi observado que a concentração da tensão máxima deu-se na parte inferior e com grande intensidade.

A deformação ocorrida no Fixador Interno de Coluna é mostrado na figura 47. 
Tabela 6 - Resultados gerais realizados nos ensaios de flexão lateral

(liga de alumínio)

\begin{tabular}{|c|c|c|c|c|c|c|c|c|c|c|}
\cline { 2 - 11 } \multicolumn{1}{c|}{} & \multicolumn{8}{c|}{ Resultados das variações das tensões (MPa) } \\
\hline Ensaios & & & & & & & & & & \\
\hline 1 & -2027 & -1563 & -1098 & -633.369 & -168.692 & 295.985 & 730.662 & 1225 & 1690 & 2155 \\
\hline 2 & -1553 & -1197 & -841.348 & -485.547 & -129.745 & 226.056 & 581.857 & 937.658 & 1293 & 1649 \\
\hline 3 & -979.512 & -755 & -530.488 & -305.977 & -81.465 & 143.047 & 367.559 & 592.071 & 816.582 & 1041 \\
\hline 4 & -847.511 & -653.262 & -459.014 & -264.765 & -70.516 & 123.733 & 317.981 & 512.23 & 706.479 & 900.728 \\
\hline 5 & -675.43 & -520.621 & -365.812 & -211.003 & -56.195 & 98.614 & 253.423 & 408.232 & 563.041 & 717.85 \\
\hline 6 & -446.157 & -343.969 & -241.781 & -139.594 & -37.406 & 64.782 & 166.97 & 269.157 & 371.345 & 473.533 \\
\hline 7 & -362.537 & -279.443 & -196.349 & -113.255 & -30.161 & 53.933 & 133.027 & 219.121 & 302.215 & 385.309 \\
\hline
\end{tabular}

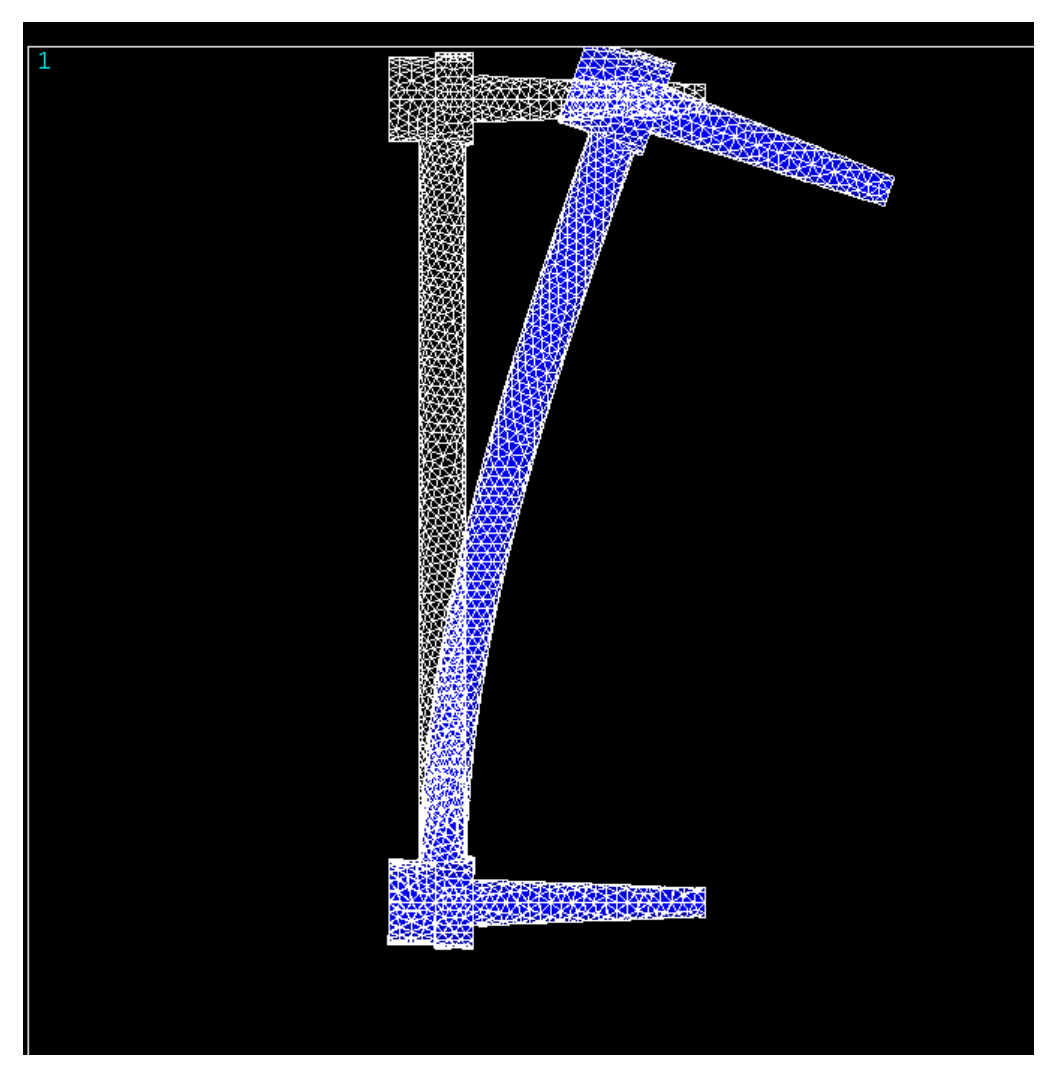

Fig. 47 - Deformação sofrida pelo fixador de alumínio (liga) no ensaio flexão lateral com carga de $0,0365 \mathrm{KN}$ 


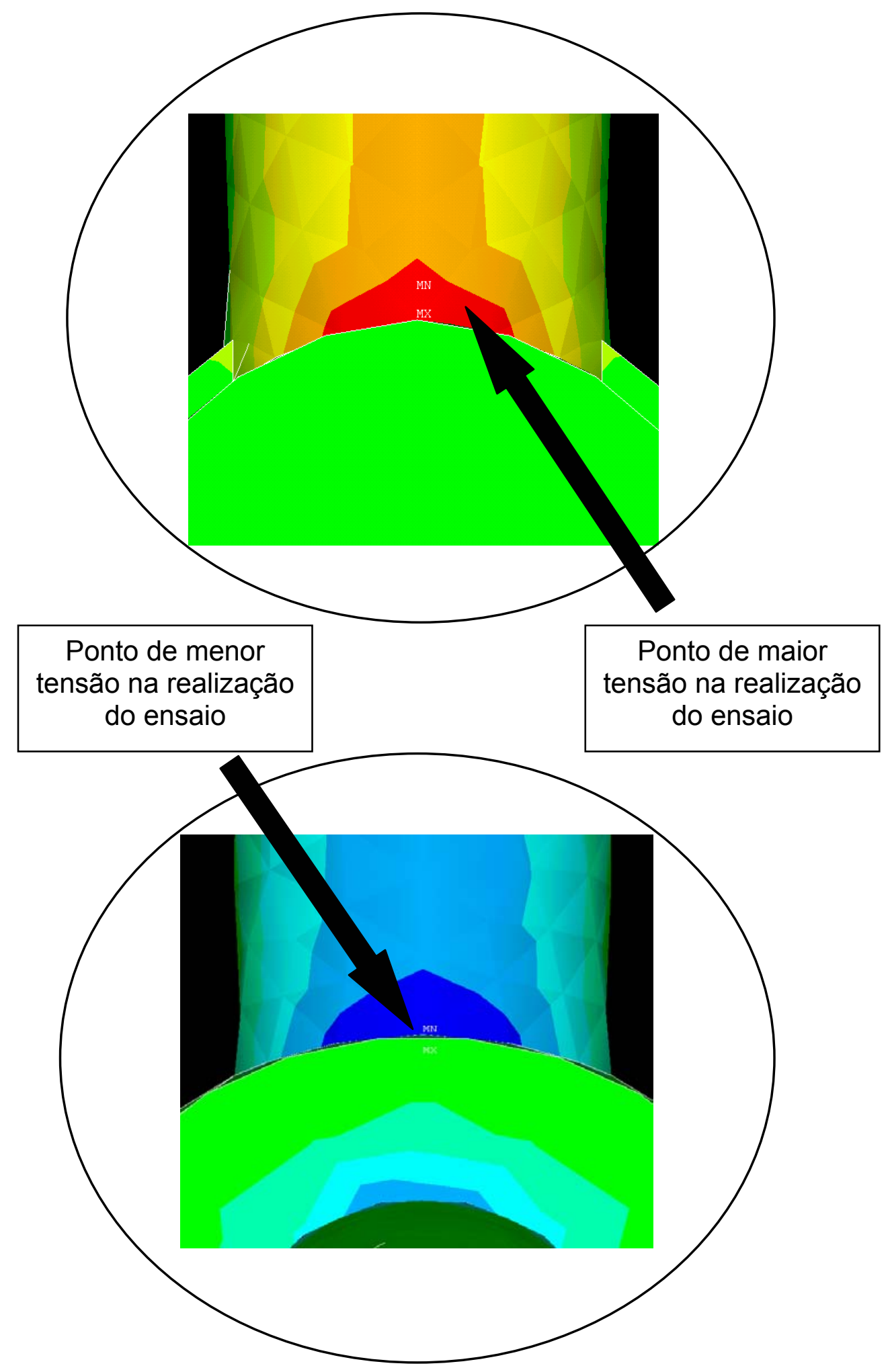

46 - (A), (B) Ponto de maior e menor tensão no fixador de alumínio (liga) durante o ensaio de flexão lateral 


\subsection{CÁlCULO DAS TENSÕES APLICADAS}

As unidades utilizadas neste trabalho são aquelas definidas no sistema internacional (SI). Para a tensão, tem-se:

$$
\sigma=P=\frac{F}{A}
$$

Neste sistema a força é dada em Newton $(\mathrm{N})$, a área em $\mathrm{m}^{2}$ e a tensão em Pascal $(\mathrm{Pa})$.

Portanto:

$$
1 \mathrm{MPa}=10^{6} \frac{\mathrm{N}}{\mathrm{m}^{2}} \quad 1 \mathrm{Gpa}=10^{9} \frac{\mathrm{N}}{\mathrm{m}^{2}}
$$

logo:

$$
1 \frac{N}{m^{2}}=10^{-6} \frac{N}{m^{2}} \quad 1 \frac{N}{m^{2}}=10^{6} \mathrm{~Pa}
$$

\subsection{COMPARAÇÃO GRÁFICA DAS SIMULAÇÕES DOS FIXADORES}

Através dos resultados obtidos nos ensaios de flexocompressão realizados no fixadores de titânio (liga) e alumínio (liga) foram traçados os gráficos das figuras 50 e 51, onde foram aplicadas as variações das cargas de 0,0365 KN a 0,0065 KN. 


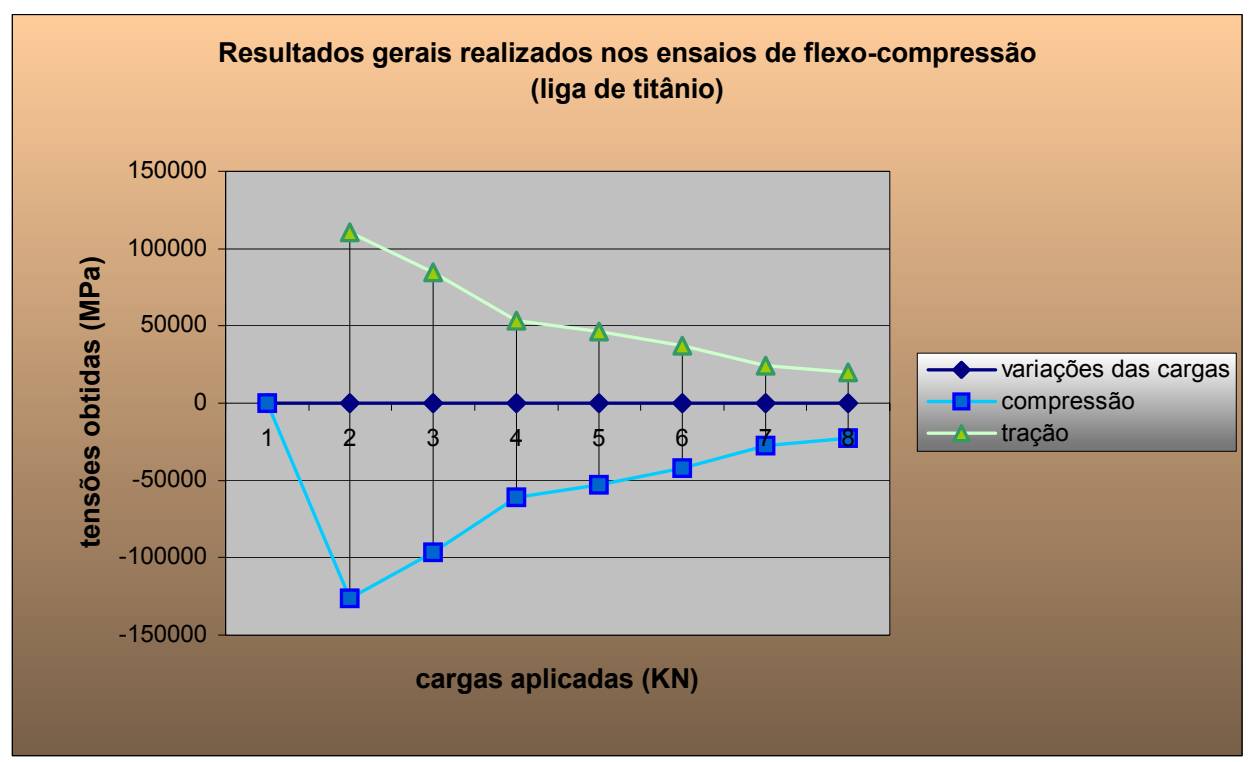

Fig. 48 - Gráfico das cargas aplicadas $x$ tensões obtidas nos ensaios de flexo-compressão do fixador de titânio

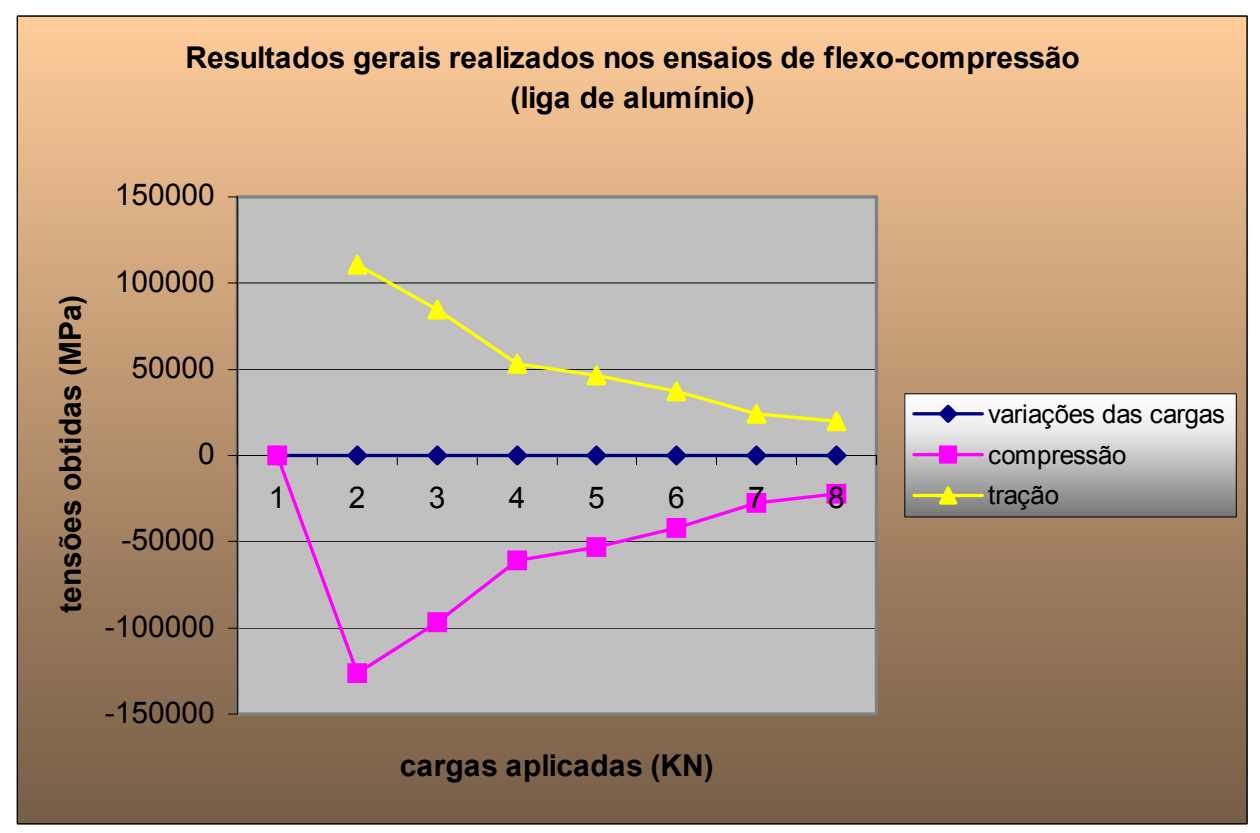

Fig. 49 Gráfico das cargas aplicadas $x$ tensões obtidas nos ensaios de flexo-compressão do fixador de alumínio

Os gráficos das figuras 52 e 53 mostram as variações das tensões no ensaio de flexão lateral realizados nos fixadores de titânio (liga) e alumínio (liga), onde foram aplicadas as cargas de 0,0365 KN a $0,0065 \mathrm{KN}$. 


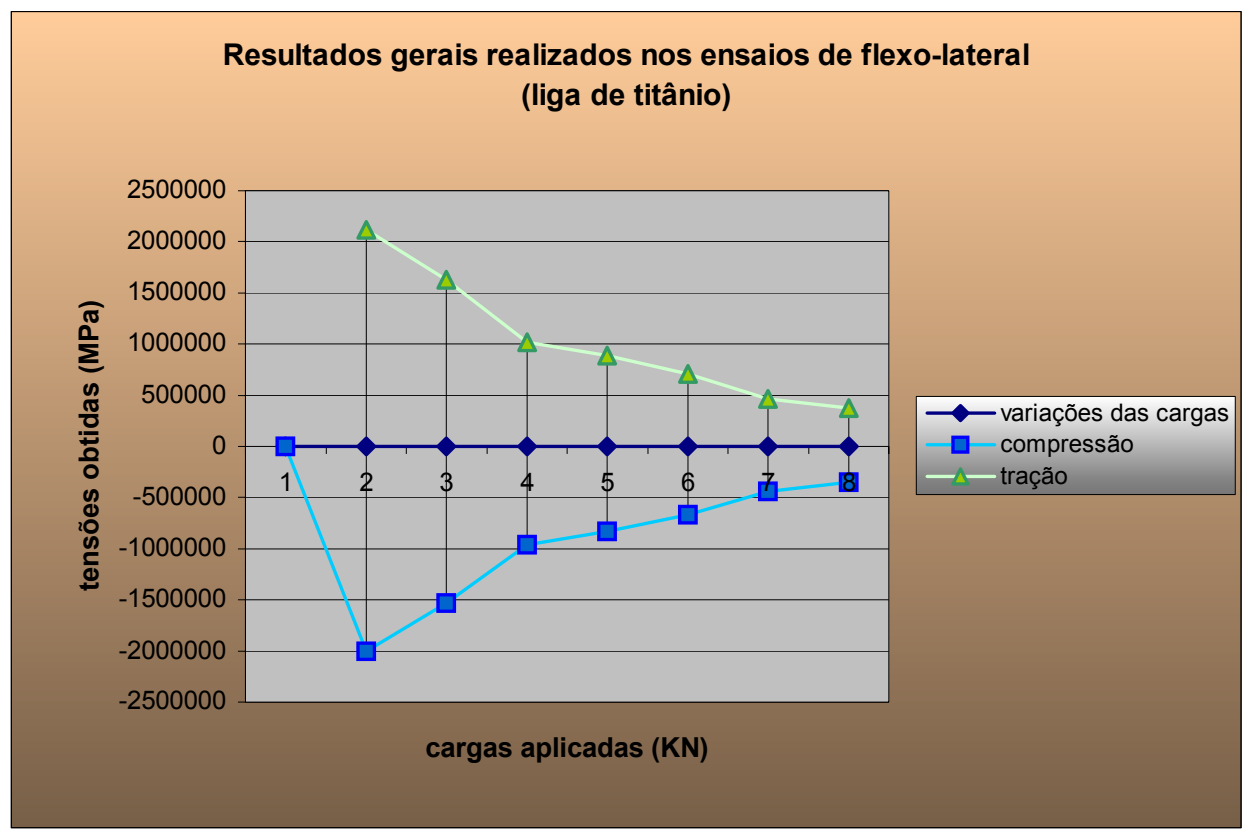

Fig. 50 Gráfico das cargas aplicadas $x$ tensões obtidas nos ensaios de flexão lateral do fixador de titânio

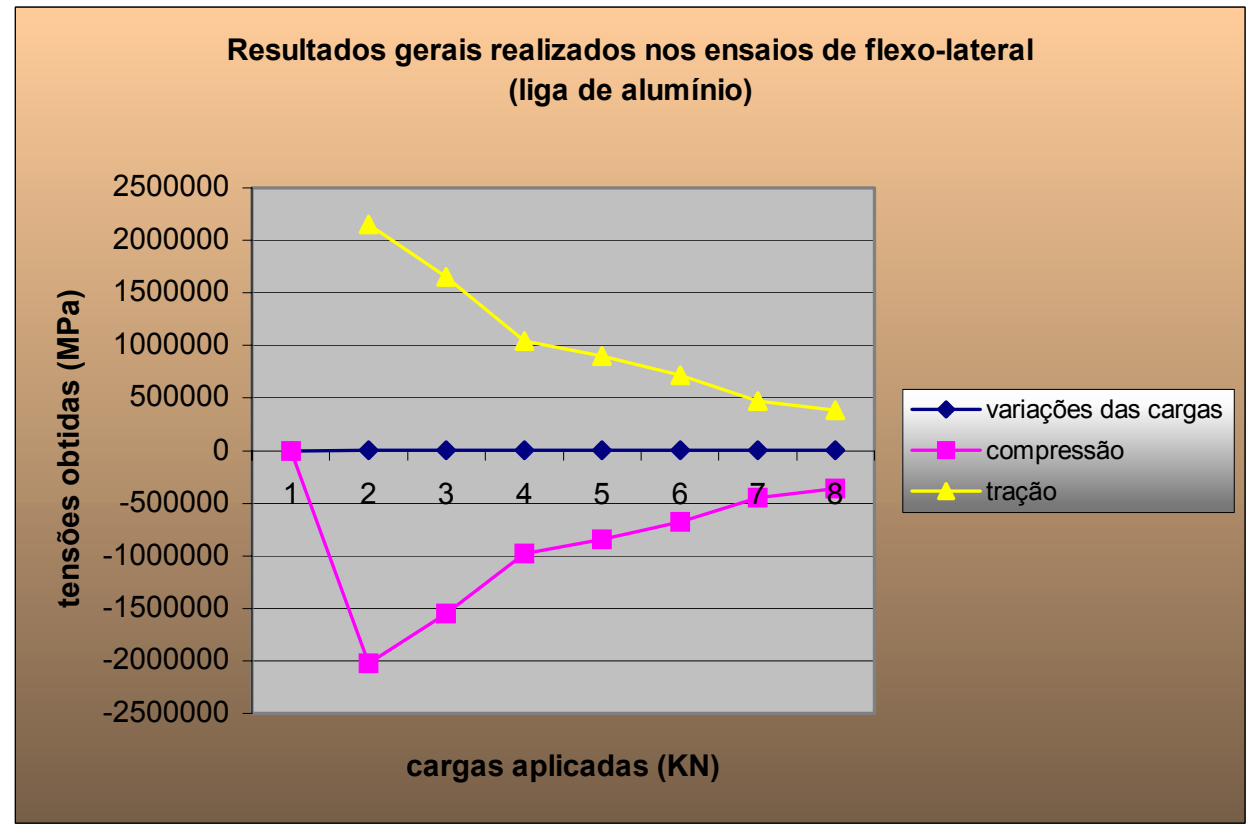

Fig. 51 Gráfico das cargas aplicadas $x$ tensões obtidas nos ensaios de flexão lateral do fixador de alumínio 


\section{DISCUSSÃO}

O importante deste trabalho está na utilização do computador para as simulações de ensaios que eram feitos na máquina universal de ensaio. A economia do tempo e dinheiro é um fator importante em todas as áreas de atuação, assim ao realizarmos uma simulação computadorizada não teremos que construir novos corpos de provas em qualquer alteração que possa surgir. A aplicação de diversas propriedades também pode variar de simulação para simulação e isso passa a ser um detalhe pequeno, pois o software permite a variação das propriedades sem a necessidade da construção de um novo modelo.

A máquina universal de ensaios é um equipamento que realiza ensaios mecânicos através da aplicação de cargas e mostra o seu resultado em um relógio comparador.

A utilização do método dos elementos finitos (MEF), vem como auxílio para análises complexas de destruição de cargas onde é possível conhecer, com maior precisão o valor das tensões resultantes em determinados pontos de interesse.

A generalização de meios de cálculos automáticos potentes tem possibilitado o recurso da utilização do método dos elementos finitos. Com a aproximação das soluções fornecidas por este método, o desconhecimento dos seus fundamentos pode conduzir a resultados desastrosos. Embora as formulações não convencionais do método dos 
elementos finitos mostrem diversas vantagens, a formulação convencional de elementos finitos de deslocamentos compatíveis é a mais simples e utilizada na prática.

Uma das vantagens do método dos elementos finitos sobre vários outros métodos aproximados, assim como o método das diferenças finitas, é precisamente a facilidade de aplicações de domínios e condições de fronteiras complicadas. Ao utilizar um programa de cálculo automático, é conveniente escolher elementos finitos do grau mais elevado que estejam disponíveis. Os programas de cálculos automáticos comerciais para análise de estruturas permitem uma escolha muito limitada de tipos de elementos finitos e só dispõem de elementos finitos de grau relativamente baixo, pelo que a subdivisão do domínio é quase sempre inevitável, PEREIRA (2000).

Os fixadores utilizados são aqueles que fazem parte do trato clínico e que já foram utilizados em trabalhos de simulação na máquina universal de ensaios. Hoje sabe-se que o material mais utilizada na fixação da coluna vertebral é o titânio devido a sua biocompatibilidade e resistência.

Na revisão da bibliografia foi verificado um número muito escasso de trabalhos que envolviam a utilização de um software de elementos finitos na área médica. Alguns trabalhos envolviam a simulação, mas realizada na máquina universal de ensaios (BRYAN et al., 1993, ), diferenciando o realizado neste trabalho. 
Assim, de uma forma geral, o método dos elementos finitos (MEF) pode ser encarado como um método numérico aproximado, para solucionar equações diferenciais, com precisão aceitável para engenheiros. Seu desenvolvimento inicial foi utilizado em aplicações de análise estrutural em aeronaves, utilizando o princípio de equilíbrio de forças e análise matricial. Posteriormente foi aplicado a outros fenômenos, sendo atualmente utilizado na solução de muitos problemas, dentre os quais pode-se citar: análise de tensões, vibrações, injeção de plástico, etc., tanto para modelar fenômenos lineares como não-lineares, LUERSEN (2000).

Hoje pode-se colocar a utilização de elementos finitos na área médica, principalmente na ortopedia como é o caso deste trabalho. 0 trabalho deverá ter continuidade com a modelagem do conjunto da estrutura óssea (coluna vertebral) e a devida fixação verificando o comportamento do fixador interno de coluna " $X$ " estrutura óssea, com a finalidade de dar uma visão do sistema aos médicos antes de uma cirurgia. Este trabalho verificou o comportamento do fixador interno de coluna dando uma visão geral dos pontos de maior e menor tensão ou seja analise de compressão e tração e uma visualização da deformação sofrida em fixadores de metais diferentes.

A utilização do software ANSYS ${ }^{\circledR}$ possibilitou a modelagem do sólido (fixador interno de coluna vertebral), mas pela facilidade oferecida foi utilizado o software Solid Edge ${ }^{\odot}$, que é um software próprio para engenharia. Com este software a modelagem de todas as peças do 
fixador interno de coluna vertebral e também do conjunto, foram perfeitas.

O Solid Edge ${ }^{\odot}$ dá a flexibilidade da exportação do conjunto para o ANSYS ${ }^{\circledR}$, devido ao recurso de salvamento com a extensão IGES. O ANSYS ${ }^{\circledR}$ apresenta em seus dados a aceitação de sólidos modelados em outros programas, mas somente com as extensões compostas em sua biblioteca.

O desenvolvimento do trabalho passou por um obstáculo, pois o sólido no software $\operatorname{ANSYS}^{\circledR}$ não possuía volume, mas graças a recursos oferecidos pelo mesmo, foi aplicado o volume em toda a estrutura.

A maior parte do tempo consumido no desenvolvimento do trabalho foi no aprendizado dos dois softwares utilizados, mas que resultou em um trabalho detalhado e com informações importantes para continuidade da pesquisa.

Para a realização das simulações foi utilizado um computador Pentium III, processador $750 \mathrm{MHz}$, sistema operacional Windows 98, 64 Mbytes de memória, HD de 20 Gigabytes e foi verificado que o processamento era muito lento, assim foi acrescida a memória mais 64 Mbytes, tornando a resposta do processamento da simulação mais rápido.

Durante os ensaios de flexo-compressão e flexão lateral com a aplicação das cargas fornecidas na tabela 2, foi verificado no início da pesquisa que o sólido era destruído por completo, pois a carga era 
aplicada a cada nó tornando-se insuportável para o objeto. Feita a correção a simulação passou a fluir como o esperado.

A variação da densidade da malha, a diferença na geometria, as condições de carregamento, como também as propriedades do material tornaram-se fundamentais aos procedimentos com atribuição de: elementos, material, condições de carregamento, fixação e aspectos geométricos importantes para a validação do ensaio.

Através destes fatores, foi observado que a deformação sofrida pelo fixador interno de coluna vertebral de alumínio (liga) era maior que o titânio (liga), mas os pontos e valores de maior e menor tensão eram parecidos. Havia uma pequena diferença devida ao número de elementos selecionados durante os ensaios.

$\mathrm{Na}$ comparação dos dois fixadores através do gráfico é possível verificar que a tração e compressão são quase as mesmas para ambas as simulações de flexo-compressão e flexão lateral. Este resultado já era esperado, pois em outros trabalhos de simulação realizados na máquina universal de ensaios o resultado foi parecido. Também podemos verificar que quanto menor a carga aplicada, maior a tendência da tensão se aproximar do zero.

Os grandes desafios para a continuidade deste trabalho serão a modelagem da coluna vertebral e a identificação das propriedades do osso (anisotrópico), com isto há evidente a necessidade de novos estudos que serão somados a esta pesquisa. 


\section{CONCLUSÕES}

A partir da soma dos resultados obtidos na realização desta pesquisa, pode-se chegar as seguintes conclusões:

1 - O sofware Solid Edge se mostrou eficiente para a modelagem das peças do fixador e do conjunto;

2 - O software ANSYS que utiliza o método dos elementos finitos permitiu analisar partes específicas de interesse no fixador;

3 - Através do ANSYS foi verificado os valores da compressão e da tensão mostrados no programa através de um degrade de cores;

4 - Foi possível verificar os pontos de maior e menor tensão nas peças representados no programa pelas letras $\mathrm{MX}$ e $\mathrm{MN}$;

5 - A deformação dos fixadores de liga de titânio e liga de alumínio foram comparadas;

6 - Através do programa é possível realizar alterações nos modelos sem a necessidade da construção de novos;

7 - Vários ensaios podem ser realizados em um único modelo;

8 - Com profissionais experientes no manuseio dos softwares as simulações que eram realizados na máquina universal de ensaios poderão ser realizadas no computador. 


\section{REFERÊNCIAS BIBLIOGRÁFICAS ${ }^{1}$}

ADAMS, J. C.; HAMBLEN, D. L. Manual de fraturas. 10ª ed. São Paulo: Ed. Artes Médicas, 1994. Cap. 8, p. 99-107.

ALLEN, JR. B.; FERGUNSON, R.; LEHMANN, T. A mechanistic classification of closed, Indirect fractures and dislocations of the lower cervical spine. Spine, v. 7, p. 1-27, 1982.

ANSYS ${ }^{\circledR}$, versão 5.5. [S.I.]: ANSYS Inc. Corporate Information, 1994. Conjunto de programas.1 CD-ROM.

ANSYS ${ }^{\circledR}$ 5.5. Complete User's Manual. 10 ed. Inc. Product Documentation, 1998.

APLEY, A. G.; Ortopedia e fraturas em medicina e reabilitação. $6^{a}$ ed. São Paulo: Atheneu, 1998. Cap. 25, p. 435-448.

BRASIL, A. V. B.; COELHO, D. G.; LEIVAS, T. P.; PEREIRA, C. A. M.; FILHO, T. E. P. B.; BRAGA, F. M. Um método para medida de movimento em estudos biomecânicos de coluna vertebral. Revista Brasileira de Ortopedia, v. 34, n. 2, p. 109-112, 1999.

BASILE JR., R.; FILHO, T. E. P. B.; OLIVEIRA, R. P.; UHLENDORFF, E. F. V.; PEDROSA, F. M.; NARDELLI, J.; AMATUZZI, M. M. Lesões da coluna vertebral nos esportes. Revista Brasileira de Ortopedia, v. 34, n. 2, p. 9096, 1999.

BRYANT, C. E.; SULLIVAN, J. A. Management of thoracic and lumbar spine fractures with Harrington distraction rods supplemented with segmental wiring. Spine, v. 8, p. 532-537, 1983.

\footnotetext{
${ }^{1}$ Referências bibliográficas de acordo com as normas da ABNT, 2002.
} 
CRISTANTE, A. F.; GEBRIN, A. S.; SORILHA, A.; MARCON, R. M.; FILHO, T. E. P. F.; OLIVEIRA, R. P. Novo sistema de classificação das lesões traumáticas da coluna vertebral: Estudo crítico de 100 casos. Revista de Medicina, v. 77, n. 1, p. 45-54, 1998.

CUNNINGHAM, B. W.; SEFFER, J. C.; SHONO, Y.; MCAFEE, P. C. Static and cyclical biomechanical analysis of pedicle screw. Spine, v. 18, n. 2, p. 1677-1688, 1993.

DEFINO, H. L. A.; FUENTES, A. E. R.; REMONDI, P. H.; VALLIM, E. C. Fixação monossegmentar das fraturas da coluna toracolombar. Revista Brasileira de Ortopedia, v. 33, n. 2, p. 119-124, 1998.

DEFINO, H. L. A. Avaliação da angulação dos parafusos e utilização do estabilizador transversal na estabilidade do sistema de fixação pedicular. Revista Brasileira de Ortopedia, v. 31, n. 11, 1996.

DENIS, F. The Three Colunm Spine and its significance in the classification of acute thoracolumbar spinal injures. Spine, v. 7, p. 1-27, 1990.

FILHO, T. E. P. B.; NETTO, A. B. F. M.; JUNIOR, R. B.; TARICCO, M. A.; NAPOLI, M. M. M. Tratamento das fraturas - luxações do segmento toracolombar da coluna pelo método de Harrington - Luque. Revista Brasileira de Ortopedia, v. 23, n. 5, p. 115-119, 1998.

FILHO, T. E. P. B.; ROSSI, J. D. M. B. A. Prevenção de Fraturas da coluna vertebral. Revista de Medicina, v. 71, n. 6, p. 8-89, 1992.

HARRINGTON, P. R. Treatment of scoliosis. Correction and internal fixation by spine instrumentation. J. Bone Joint Surg, p. 591-610, 1962.

HOLDSWORTH, F. A fractures, dislocations and fractures dislocations of the spine. J. Bone and Joint Surgery, v. 45, p. 6-20, 1963.

HOLDSWORTH, F. Fractures, dislocations and fractures dislocations of the spine. J. Bone and Joint Surgery, v. 52, p. 1534-1551, 1970. 
JACOBS, C. R.; LEVENSTON, M. E.; BEAUPRÉ, G. S.; SIMO, J. C.; CARTER, D. R. Numerical instabilities in bone remodeling simulations: The advantages of a node-based finite element approach. J. Biomechanics, v. 28, n. 4, p. 449-459, 1995.

LEVINE, A. M.; Atualização em conhecimentos ortopédicos: trauma. São Paulo: Atheneu, 1998. Cap. 30, 36, p. 285-291, p. 325-332.

LOUIS, R. Fusion of the lumbar sacral spine by internal fixation with screws plates. Clin Orthop, v. 203, p. 75-98, 1986.

LUERSEN, M. A. Métodos numéricos para a engenharia. Paraná: CEFET/DAMEC, p. 1-64, 2000.

MAGERL, F. The spine. AO Classifications, v. 5, p. 1-25, 1989.

MARTINS, J. W. G. Fixação de coluna vertebral com parafusos transpediculares. Disponível em: http://santalucia.com.br/neurologia/colunavertebral/defaul. Acesso em: 20 mar. 2000.

MERCÚRIO, R. O que você deve saber sobre coluna vertebral. $2^{a}$ ed. São Paulo: Nobel, 1978. p 8-89.

MatWeb. The Online Materials Information Resourse. Disponível em: http://www.matweb.com . Acesso em: 29 Jan. 2001.

PEREIRA, O. J. B. A. Introdução ao método dos elementos finitos na análise de problemas planos de elasticidade. Instituto Superior Técnico, p. 1-52, 2000

PUTZ, R. \& PABST, R. Sobotta : Atlas de anatomia humana. 20 ed. Rio de Janeiro: Guanabara/Koogan, 1993.

RAKOTOMANANA, R. L.; LEYVRAZ, P. F.; HEEGAARD, J. H.; RUBIN, P. J. A finite model for evalution of tibial prosthesis-bone interface in total knee replacement. J. Bone and Joint Surg, v. 25, n. 25, p. 1413-1424, 1992. 
ROAF, R. A study of the mechanics of spinal injuries. J. Bone and Joint Surg, v. 10, p. 810-823, 1960.

ROAF, R. International classification of spinal injures. Paraplegia, v. 10, p. 18-84, 1972.

SERDEIRA, A.; FILHO, T. E. P. B.; PUERTAS, E. B.; FILHO, J. L.; LEIVAS, T. P. Estudo mecânico de implante para fixação do segmento lombossacro da coluna vertebral. Acta Ortopédica Brasileira, v. 08, n. 03, p. 112-121, 2000.

SHIMANO, A. C. Análise das Propriedades Geométricas e Mecânicas de Tíbia Humana: Proposta de Metologia. 1994. Tese (Doutorado) - Escola de Engenharia de São Carlos, Universidade de São Paulo, São Carlos.

SOLID EDGE, versão 8.0 [S. I.]: Unigraphics Solutions Inc. Conjunto de programas 1 CD-ROM.

SOUZA, S. A. Ensaios Tecnológicos dos Matérias. São Paulo: McGrawHill, 1977.

YEH, O. C.; KEAVENY T. M. Biomechanical effects of intraspecimen variations in trabecular architecture: a three-dimensional finite element study. J. Bone, v. 25, n. 2, p. 223-228, 1999.

ZAGOTTIS, D. Conceituação do Método dos Elementos Finitos. Construção Pesada, p. 44-50, 1975. 